\title{
Groundwater and Leachate Monitoring and Sampling at ERDF, CY 2006
}

\section{December 2007}

\section{Washingten Closure Hantord}

Prepared for the U.S. Department of Energy, Richland Operations Office Office of Assistant Manager for River Corridor

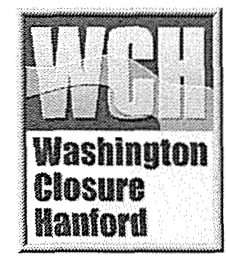


TRADEMARK DISCLAIMER

Reference herein to any specific commercial product, process, or service by trade name, trademark, manufacturer, or otherwise, does not necessarily constitute or imply its endorsement, recommendation, or favoring by the United States Government or any agency thereof or its contractors or subcontractors.

This report has been reproduced from the best available copy. Available in paper copy and microfiche.

Available for a processing fee to U.S. Department of Energy and its contractors from:

U.S. Department of Energy

Office of Scientific and Technical Information

P.O. Box 62

Oak Ridge, TN 37831-0062

(865) $576-8401$

fax: (865) 576-5728

email: reports@adonis.osti.gov

online ordering: http://www.doe.gov/bridge

Available for sale to the public, in paper, from:

U.S. Department of Commerce

National Technical Information Service

5285 Port Royal Road

Springfield, VA 22161

(800) 553-6847

fax: (703) 605.6900

email: orders@ntis.fedworld.gov

online ordering: http://www.ntis.gov/ordering.htm

Printed in the United States of America

DISCLM-5.CHP (11/99) 


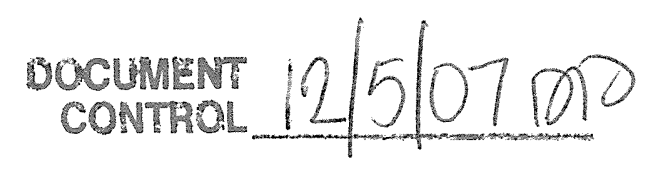

WCH-189

Rev. 1

\section{STANDARD APPROVAL PAGE}

Title: $\quad$ Groundwater and Leachate Monitoring and Sampling at ERDF, CY 2006

Author Name: R. L. Weiss

Approval: $\quad$ K. A. Hadley, Environmental Project Lead

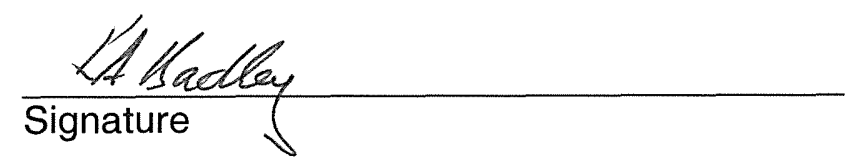

$\frac{12 / 5 / 07}{\text { Date }}$

The approval signature on this page indicates that this document has been authorized for information release to the public through appropriate channels. No other forms or signatures are required to document this information release. 

WCH-189

Rev. 1

\title{
River Corridor Closure Contract If
}

\section{Groundwater and Leachate Monitoring and Sampling at ERDF, CY 2006}

December 2007

\author{
Author: \\ R. L. Weiss
}





\section{TABLE OF CONTENTS}

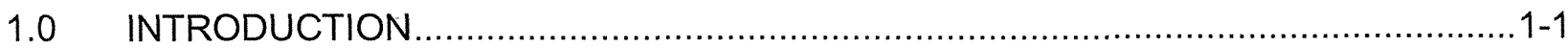

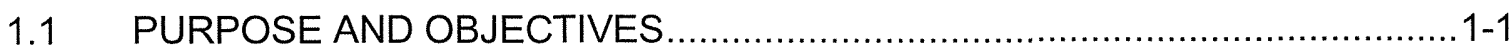

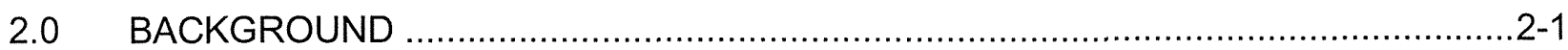

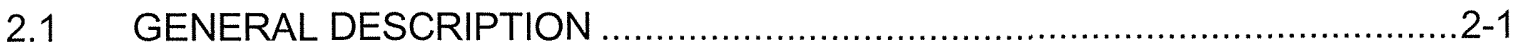

2.2 ENVIRONMENTAL RESTORATION DISPOSAL FACILITY ..........................2-1

3.0 GROUNDWATER AND LEACHATE MONITORING …..........................................

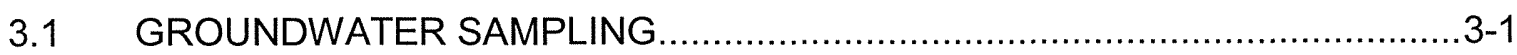

3.1.1 General Approach to Evaluating Results ............................................3-3

3.1.2 Statistical Approach to Evaluating Results .........................................3-3

3.1.3 Determination of Tolerance Intervals ...................................................

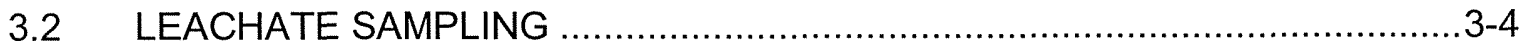

3.3 GROUNDWATER LEVELS..............................................................

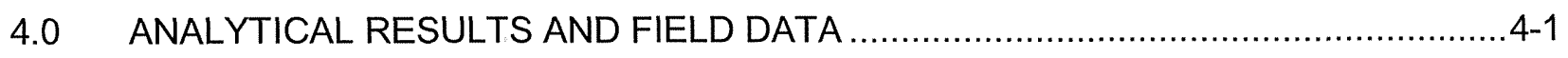

4.1 SUMMARY OF GROUNDWATER ANALYSES …………...........................4-1

4.2 SUMMARY OF LEACHATE ANALYSIS ..................................................

4.3 SUMMARY OF WATER-LEVEL MEASUREMENTS ................................... $4-6$

5.0 CONCLUSIONS AND RECOMMENDATIONS ...................................................... 5-1

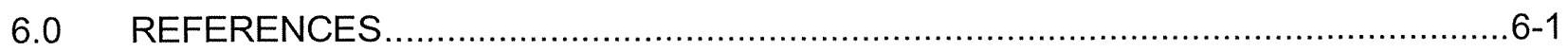




\section{APPENDICES}

A GROUNDWATER SAMPLING RESULTS, 1996-2006 ..................................... A-i

B GROUNDWATER SAMPLING TRENDS, 1996-2006 .................................... B-I

C LEACHATE SAMPLING RESULTS SUMMARY, 2004-2006 ............................ C-i

\section{FIGURES}

2-1. Location of the Environmental Restoration Disposal Facility..................................2-2

2-2. $\quad$ ERDF Monitoring Well Location Map ................................................................ $2-3$

3-1. Water-Level Contour Map ...........................................................................

3-2. Hydrograph from ERDF Groundwater Monitoring Wells ......................................... $3-7$

\section{TABLES}

3-1 List of Groundwater Analytes by Analytical Method ............................................

4-1 Summary of Tolerance Interval Comparisons and Trends ....................................... 


\section{REVISION HISTORY}

\begin{tabular}{|c|c|l|c|}
\hline Revision & Date & \multicolumn{1}{|c|}{ Reason for revision } & Revision initiator \\
\hline 0 & $05 / 2007$ & Initial issuance & NA \\
\hline 1 & $12 / 2007$ & $\begin{array}{l}\text { Section 4.1 was revised to correct typographical } \\
\text { errors and provide more detail on external sources } \\
\text { of contamination in the groundwater around ERDF } \\
\text { Section 4.3 was revised to remove a typographical } \\
\text { error. } \\
\text { Section 5.0 was revised to remove a typographical } \\
\text { error and to include expanded discussion on } \\
\text { arsenic and total organic halide analytical } \\
\text { results/trending. }\end{array}$ & R. L. Weiss \\
\hline
\end{tabular}


WCH-189

Rev. 1

GW and Leachate Monitoring and Sampling at ERDF, CY 2006 


\section{ACRONYMS}

$\begin{array}{ll}\text { COC } & \text { contaminant of concern } \\ \text { CY } & \text { calendar year } \\ \text { DOW } & \text { description of work } \\ \text { ERDF } & \text { Environmental Restoration Disposal Facility } \\ \text { ETF } & \text { Effluent Treatment Facility } \\ \text { GPP } & \text { groundwater protection plan } \\ \text { RCRA } & \text { Resource Conservation and Recovery Act of } 1976 \\ \text { ROD } & \text { Record of Decision }\end{array}$


WCH-189

Rev. 1

GW and Leachate Monitoring and Sampling at ERDF, CY 2006 


\section{METRIC CONVERSION CHART}

\begin{tabular}{|c|c|c|c|c|c|}
\hline \multicolumn{3}{|c|}{ Into Metric Units } & \multicolumn{3}{|c|}{ Out of Metric Units } \\
\hline If You Know & Multiply By & To Get & If You Know & Multiply By & To Get \\
\hline Length & & & Length & & \\
\hline inches & 25.4 & millimeters & millimeters & 0.039 & inches \\
\hline inches & 2.54 & centimeters & centimeters & 0.394 & inches \\
\hline feet & 0.305 & meters & meters & 3.281 & feet \\
\hline yards & 0.914 & meters & meters & 1.094 & yards \\
\hline miles & 1.609 & kilometers & kilometers & 0.621 & miles \\
\hline Area & & & Area & & \\
\hline sq. inches & 6.452 & sq. centimeters & sq. centimeters & 0.155 & sq. inches \\
\hline sq. feet & 0.093 & sq. meters & sq. meters & 10.76 & sq. feet \\
\hline sq. yards & 0.836 & sq. meters & sq. meters & 1.196 & sq. yards \\
\hline sq. miles & 2.6 & sq. kilometers & sq. kilometers & 0.4 & sq. miles \\
\hline acres & 0.405 & hectares & hectares & 2.47 & acres \\
\hline Mass (weight) & & & Mass (weight) & & \\
\hline ounces & 28.35 & grams & grams & 0.035 & ounces \\
\hline pounds & 0.454 & kilograms & kilograms & 2.205 & pounds \\
\hline ton & 0.907 & metric ton & metric ton & 1.102 & ton \\
\hline Volume & & & Volume & & \\
\hline teaspoons & 5 & milliliters & milliliters & 0.033 & $\begin{array}{l}\text { fluid } \\
\text { ounces }\end{array}$ \\
\hline tablespoons & 15 & milliliters & liters & 2.1 & pints \\
\hline fluid ounces & 30 & milliliters & liters & 1.057 & quarts \\
\hline cups & 0.24 & liters & liters & 0.264 & gallons \\
\hline pints & 0.47 & liters & cubic meters & 35.315 & cubic feet \\
\hline quarts & 0.95 & liters & cubic meters & 1.308 & $\begin{array}{l}\text { cubic } \\
\text { yards }\end{array}$ \\
\hline gallons & 3.8 & liters & & & \\
\hline cubic feet & 0.028 & cubic meters & & & \\
\hline cubic yards & 0.765 & cubic meters & & & \\
\hline Temperature & & & Temperature & & \\
\hline Fahrenheit & $\begin{array}{l}\text { subtract } 32 \text {, } \\
\text { then multiply } \\
\text { by } 5 / 9\end{array}$ & Celsius & Celsius & $\begin{array}{l}\text { multiply by } 9 / 5 \text {, } \\
\text { then add } 32\end{array}$ & Fahrenheit \\
\hline Radioactivity & & & Radioactivity & & \\
\hline picocuries & 37 & millibecquerel & millibecquerels & 0.027 & picocuries \\
\hline
\end{tabular}


WCH-189

Rev. 1

GW and Leachate Monitoring and Sampling at ERDF, CY 2006 


\subsection{INTRODUCTION}

The Environmental Restoration Disposal Facility (ERDF) is a Hanford Site low-level mixed waste disposal facility that was brought into service on July 1, 1996. Baseline sampling and analytical data obtained from monitoring wells and the ERDF leachate collection system were used to determine contaminants of concern (COCs) and background conditions for long-term monitoring as described in the Groundwater Protection Plan for the Environmental Restoration Disposal Facility (ERDF GPP) (BHI 1996) and to meet the requirements of the ERDF Record of Decision (ROD) (EPA 1995). Ongoing groundwater and leachate monitoring are performed to meet the requirements of the ERDF ROD, and details of the monitoring program are described in the Description of Work for Routine Groundwater Sampling at the Environmental Restoration Disposal Facility (ERDF DOW) (BHI 2005a) and the ERDF Amended ROD (EPA 1999, 2003).

\subsection{PURPOSE AND OBJECTIVES}

The purpose of this annual monitoring report is to evaluate the conditions of and identify trends for groundwater beneath the ERDF and to report leachate results in fulfillment of the requirements specified in the ERDF ROD (EPA 1995).

The objectives of this report are as follows:

- Review routine groundwater sampling data to statistically evaluate if there have been changes in COC concentrations over time that may be attributed to ERDF operations

- Assess conditions that may indicate the presence of encroaching groundwater contaminant plumes originating from upgradient sources in the 200 West Area

- Assess data from routine ERDF leachate sampling to determine if additional constituents should be added to the ERDF groundwater monitoring COC list

- Evaluate the groundwater levels in the ERDF monitoring wells to determine if the existing wells need to be modified or replaced.

Appendix A shows analytical results for groundwater samples that were collected from the ERDF monitoring well network from calendar year (CY) 1996 through CY 2006. Appendix B graphically shows trends in the monitoring data resulting from routine groundwater sampling in the ERDF well network. The most recent 3 years of leachate analytical results for samples collected from CY 2004 through CY 2006 are presented in Appendix C. Leachate data collected from CY 1996 through CY 2003 are contained in previous ERDF groundwater and leachate monitoring reports (Faurote 2000; BHI 2002, 2003, 2004, 2005b; WCH 2006). 


\subsection{BACKGROUND}

\subsection{GENERAL DESCRIPTION}

The ERDF site is located between the 200 East and 200 West Areas of the Hanford Site (Figure 2-1). This location was selected for the ERDF over other possible locations, in part because of the depth to groundwater in this area, its location above pre-existing groundwater plumes, the relatively flat topography in this area, and the compatibility of this location with stakeholder recommendations.

The ERDF landfill is authorized under the Comprehensive Environmental Response, Compensation, and Liability Act of 1980. The landfill was designed to meet the Resource Conservation and Recovery Act of 1976 (RCRA) minimum technology requirements; however, the ERDF is not permitted as a RCRA facility. Wastes disposed at ERDF contain elevated levels of radionuclides and hazardous constituents originating from the 100, 200, and 300 Area waste sites.

\subsection{ENVIRONMENTAL RESTORATION DISPOSAL FACILITY}

There are currently six waste cells associated with the ERDF site. Initially, cells 1 and 2 were constructed and the placement of waste in these cells has since been completed. Cells 3 and 4 were constructed in 2000. Construction of cells 5 and 6 was completed during CY 2004, and two additional cells are scheduled to begin construction in the late fall of 2007. All six cells are roughly equal in size. Figure 2-2 shows the ERDF as it is currently constructed. Throughout CY 2006, approximately $525,613.5$ metric tons of remediation wastes were disposed at the facility. 
Figure 2-1. Location of the Environmental Restoration Disposal Facility.

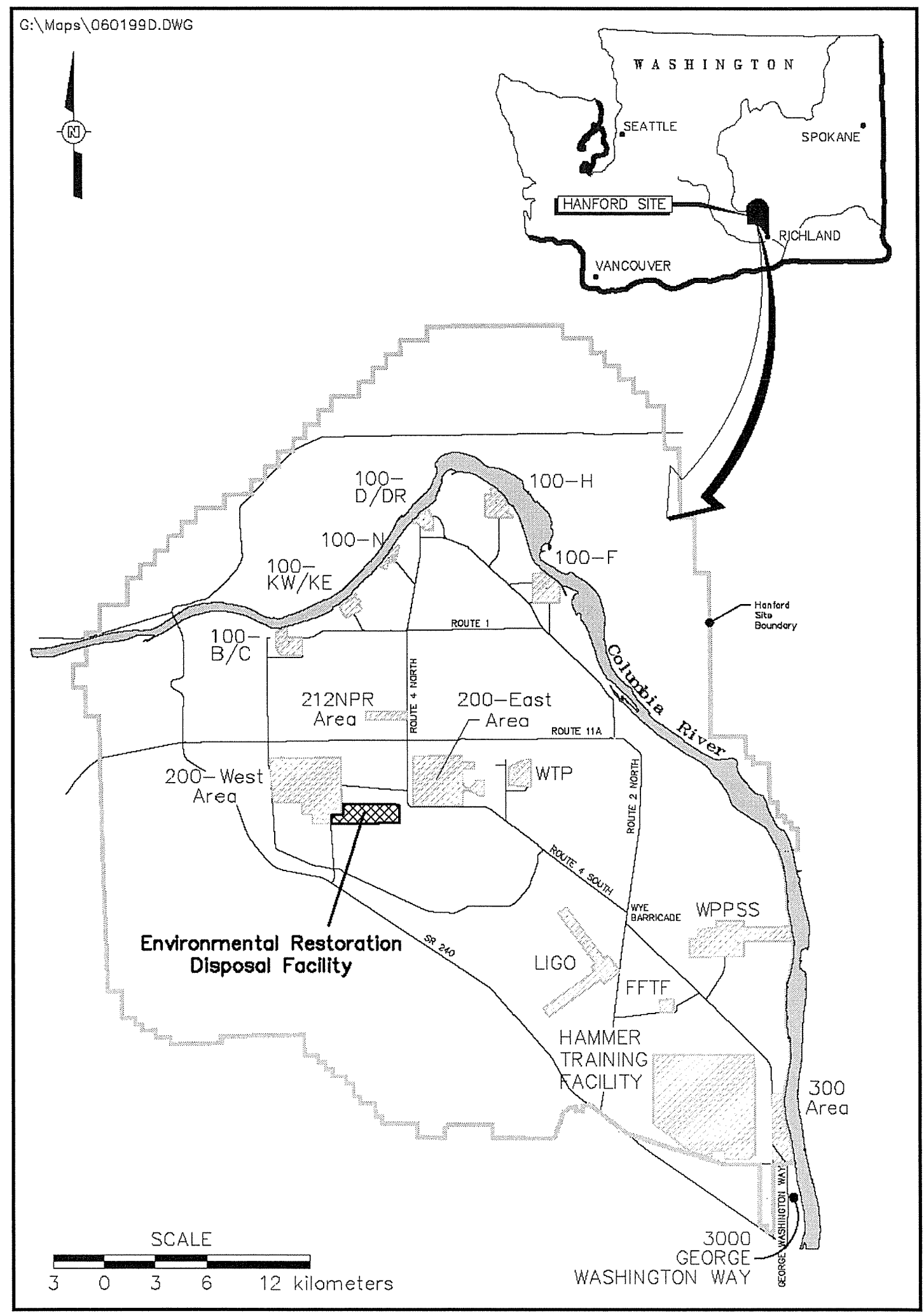


Figure 2-2. ERDF Monitoring Well Location Map.

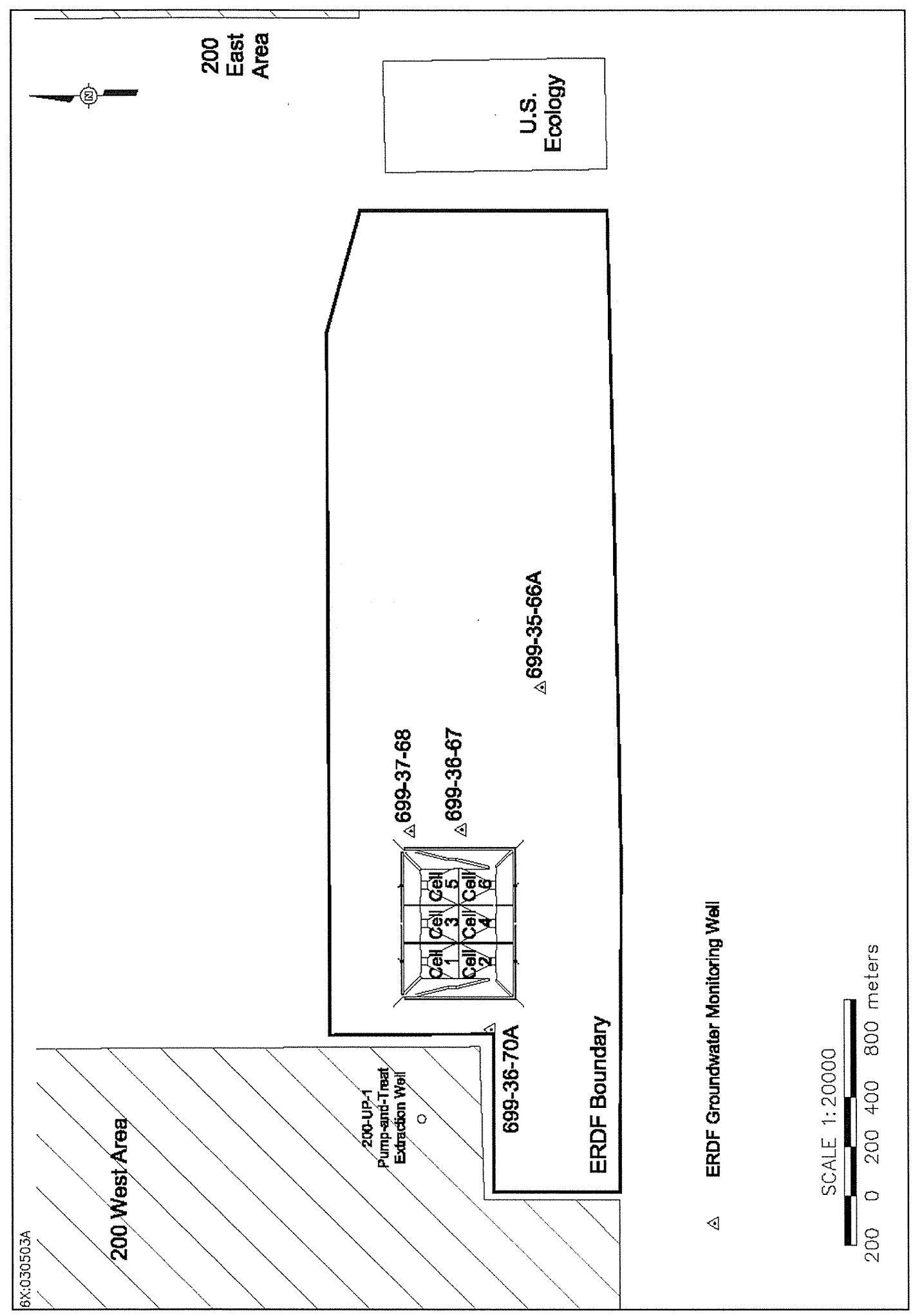




\subsection{GROUNDWATER AND LEACHATE MONITORING}

The groundwater and leachate monitoring program is described in the ERDF GPP (BHI 1996). This section provides an overview of these monitoring requirements.

\subsection{GROUNDWATER SAMPLING}

Groundwater samples are collected semiannually from four monitoring wells in the vicinity of the ERDF. This monitoring well network is scheduled for routine sampling during the first and third quarters of each year. The monitoring well network consists of one upgradient well (699-36-70A) and three downgradient wells (699-35-66A, 699-36-67, and 699-37-68). During CY 2006, groundwater sampling was completed at all of the ERDF monitoring wells in March and September. Well locations are shown in Figure 2-2.

Guidelines for determining COCs for routine groundwater monitoring are described in the ERDF DOW (BHI 2005a). The COCs for routine monitoring were determined based on the results of preoperational baseline sampling conducted in March 1996 and known contaminant plumes beneath the ERDF. Additional COCs may be added to the groundwater monitoring program if analytical results from leachate sampling indicate it is warranted. To date, no additional COCs have been identified for addition to the groundwater lists based on leachate analysis results. Table 3-1 lists the analytes for the groundwater monitoring program. Some alternate analytical methods were employed for the CY 2006 sampling other than those identified in $\mathrm{BHI}$ (2005a). The alternate methods achieved all analytical criteria (e.g., detection limits, precision and accuracy criteria) specified and significantly streamlined the analytical process at the laboratory.

Routine groundwater sampling has been conducted since ERDF operations commenced. Sampling at the ERDF groundwater wells was not completed during March 2000 due to a Hanford Site moratorium on groundwater sampling, and well 699-37-68 was not sampled during September 2000 because of problems with a dedicated monitoring well pump (BHI 2004). 
Table 3-1. List of Groundwater Analytes by Analytical Method.

\begin{tabular}{|c|c|c|c|c|}
\hline Analyte & Method $^{a}$ & $\begin{array}{c}\text { Practical } \\
\text { Quantitation } \\
\text { Limit }\end{array}$ & $\begin{array}{c}\text { Accuracy }^{b} \\
(\%)\end{array}$ & $\begin{array}{l}\text { Precision } \\
\text { (\%) }\end{array}$ \\
\hline Arsenic & $6010 \mathrm{~A}$ & $10 \mu \mathrm{g} / \mathrm{L}$ & \pm 25 & \pm 25 \\
\hline Barium & $6010 \mathrm{~A}$ & $20 \mu \mathrm{g} / \mathrm{L}$ & \pm 25 & \pm 25 \\
\hline Chromium & $6010 \mathrm{~A}$ & $70 \mu \mathrm{g} / \mathrm{L}$ & \pm 25 & \pm 25 \\
\hline Lead & $6010 \mathrm{~A}$ & $40 \mu \mathrm{g} / \mathrm{L}$ & \pm 25 & \pm 25 \\
\hline Selenium & $6010 \mathrm{~A}$ & $750 \mu \mathrm{g} / \mathrm{L}$ & \pm 25 & \pm 25 \\
\hline Tin & $6010 \mathrm{~A}$ & $30 \mu \mathrm{g} / \mathrm{L}$ & \pm 25 & \pm 25 \\
\hline Vanadium & $6010 \mathrm{~A}$ & $80 \mu \mathrm{g} / \mathrm{L}$ & \pm 25 & \pm 25 \\
\hline Zinc & $6010 \mathrm{~A}$ & $20 \mu \mathrm{g} / \mathrm{L}$ & \pm 25 & \pm 25 \\
\hline Carbon tetrachloride & $8260 \mathrm{~B}$ & $5 \mu \mathrm{g} / \mathrm{L}$ & \pm 25 & \pm 25 \\
\hline Alkalinity & $310.1^{c}$ & $10,000 \mu \mathrm{g} / \mathrm{L}$ & \pm 20 & \pm 25 \\
\hline Chloride & $300^{d}$ & $10,000 \mu \mathrm{g} / \mathrm{L}$ & \pm 20 & \pm 25 \\
\hline Fluoride & $300^{d}$ & $100 \mu \mathrm{g} / \mathrm{L}$ & \pm 20 & \pm 25 \\
\hline Nitrogen (in nitrite/nitrate) & 353.1 & $0.05 \mu \mathrm{g} / \mathrm{L}$ & \pm 20 & \pm 25 \\
\hline Sulfate & $300^{d}$ & $2,000 \mu \mathrm{g} / \mathrm{L}$ & \pm 20 & \pm 25 \\
\hline Total dissolved solids & $160.1^{c}$ & $10,000 \mu \mathrm{g} / \mathrm{L}$ & \pm 20 & NA \\
\hline Total organic halides & 9020 & $5 \mu \mathrm{g} / \mathrm{L}$ & \pm 20 & NA \\
\hline Carbon-14 & e & $200 \mathrm{pCi} / \mathrm{L}$ & \pm 20 & \pm 25 \\
\hline lodine-129 & $\mathrm{e}$ & $5 \mathrm{pCi} / \mathrm{L}$ & \pm 20 & \pm 25 \\
\hline Technetium-99 & e & $10 \mathrm{pCi} / \mathrm{L}$ & \pm 20 & \pm 25 \\
\hline Radium & $903.1^{f}$ & $1 \mathrm{pCi} / \mathrm{L}$ & \pm 20 & \pm 25 \\
\hline Total uranium & $\mathrm{e}$ & $0.1 \mu \mathrm{g} / \mathrm{L}$ & \pm 20 & \pm 25 \\
\hline Gross alpha & $900.0^{f}$ & $3 \mathrm{pCi} / \mathrm{L}$ & \pm 20 & \pm 25 \\
\hline Gross beta & $900.0^{f}$ & $4 \mathrm{pCi} / \mathrm{L}$ & \pm 20 & \pm 25 \\
\hline $\mathrm{pH}$ & $g$ & NA & NA & NA \\
\hline Specific conductance & 9 & $25 \mu \mathrm{S} / \mathrm{cm}$ & \pm 20 & NA \\
\hline Turbidity & $180.1^{c}$ & $0.05 \mathrm{NTU}$ & \pm 0.05 NTU & NA \\
\hline
\end{tabular}

a Method number indicated is from Test Method for Evaluating Solid Wastes: Physical Chemical Methods (SW-846) (EPA 1986), unless otherwise specified.

b Accuracy is expressed as percent recovery; precision is expressed as a percent relative difference.

c Method specified is from Methods for Chemical Analysis of Water and Wastes (Kopp and McKee 1983).

d Method specified is from Determination of Inorganic Anions in Aqueous and Solids Samples by Ion Chromatography (Lindahl 1984), and is a modification of EPA Method 300.0.

e Industry standard method, laboratory-specific, based on acceptance by Washington Closure Hanford.

$f$ Method specified is from Prescribed Procedures for Measurement of Radioactivity in Drinking Water (EPA 1980).

9 Parameter will be measured in the field.

$\mathrm{NA}=$ not available, or not applicable

NTU $=$ nephelometric turbidity units 


\subsubsection{General Approach to Evaluating Results}

Groundwater samples collected from the ERDF monitoring well network were analyzed in accordance with the requirements of U.S. Environmental Protection Agency SW-846 (EPA 1986), industry standard, or laboratory-specific test methods as presented in Table 3-1. Laboratory results for these samples were entered into the Hanford Environmental Information System, a Hanford Site database that contains environmental analytical data. Groundwater monitoring data contained in the Hanford Environmental Information System were evaluated to identify the analytical results needed for inclusion in this report. The following data selection and evaluation criteria were applied:

- Quality assurance/quality control data were evaluated for the purpose of identifying potential collection or analytical problems. However, unless a problem with the data was identified during this review, the results of or a discussion regarding the quality assurance/quality control data were not included in this report.

- All data qualifiers were recorded.

- If the relative percent difference between values reported for main and duplicate samples was greater than $20 \%$, the samples were flagged in the data spreadsheet and the data evaluated to determine their applicability.

- Data acceptance based on a less than $20 \%$ relative percent difference criterion was relaxed for analytical results reported at or near the method detection limit (e.g., typically within five times the detection limit). This allows for an expected increased analytical error when values are close to the detection limit.

- Only analytical results for metals from filtered groundwater samples were used for metals evaluation.

\subsubsection{Statistical Approach to Evaluating Results}

The statistical analysis of ERDF groundwater monitoring data is based on the ERDF GPP (BHI 1996) and Hanford Site Groundwater Monitoring Setting, Sources and Methods (PNNL 2000). The ERDF GPP requires that background water quality be established from four consecutive groundwater sampling events using one of two methods. The background conditions can be determined using either facility-wide groundwater quality data or historical data from each well in the monitoring network. The first approach (facility-wide) results in a single background value for the site for each constituent to which subsequent groundwater quality data are compared. This is referred to as an interwell comparison (PNNL 2000).

The second approach (historical) results in background water quality data for each well to which the subsequent groundwater quality data are compared. This approach is referred to as an intrawell comparison (PNNL 2000). The interwell approach has been selected and used for the ERDF groundwater monitoring program because this method allows for the consideration of impacts from non-ERDF sources.

For each analyte of interest identified in the ERDF GPP, data from four preoperational sampling events at each of the four ERDF monitoring wells were grouped together into data sets. The average concentration, activity, or other appropriate measure for each analyte was determined, 
and the tolerance interval for each analyte was calculated. Two-sided tolerance intervals were developed to allow for the potential concentration decreases that may be due to the offsite migration of contaminant plumes and improvements in groundwater quality over time. Data from the subsequent semiannual monitoring events are compared to background levels and the tolerance intervals. Those constituents observed to have levels outside of the tolerance interval are evaluated to determine whether the deviation may be related to an ERDF or non-ERDF source(s).

Where analytical results report a nondetect, the detection limit value is used in this assessment. If a current measurement exceeds a tolerance interval based on the reported detection limit, it is not considered to be a confirmed exceedance and is discussed qualitatively.

\subsubsection{Determination of Tolerance Intervals}

The tolerance interval represents a concentration range that contains a specified proportion of the population with a specified probability (PNNL 2000). Both the upper and lower bounds of the interval (two-sided) were calculated. The parametric tolerance interval was determined using the following equation:

$$
\mathrm{T} I=\overline{\mathrm{X}}_{\mathrm{b}}+\mathrm{k}^{*} \mathrm{~S}_{\mathrm{b}}(\text { two }- \text { sided })
$$

where:

$\mathrm{k}=$ normal tolerance factor, which depends on the number of background samples $(\mathrm{n})$, coverage $(\mathrm{P} \%)$, and the confidence level $(\mathrm{Y})$

$\mathrm{x}_{\mathrm{b}}=$ mean of background concentrations

$\mathrm{S}_{\mathrm{b}}=$ sample standard deviation

$\mathrm{TI}=$ tolerance interval.

Coverage of $95 \%$ and a confidence level of $95 \%$ were used. Application of this equation assumes that a normal (or lognormal) distribution is a reasonable approximation of the background concentrations.

\subsection{LEACHATE SAMPLING}

Each of the ERDF cells was constructed with a double-liner system for the purpose of collecting liquids, or leachate, that may travel through the waste materials stored at the disposal site. These liquids are typically generated from natural precipitation and the application of dust control water that percolates downward through the disposed waste materials and collects on the surface of the lining material. The primary or upper liners and the secondary or lower liners each are designed to deliver leachate to sump areas. Sumps for the upper liners are independent from the sumps associated with the lower liners. The upper and lower sumps at each of the cells are routinely evacuated, and the leachate is stored in holding tanks prior to transfer to the Effluent Treatment Facility (ETF).

The leachate is sampled to provide data for leachate delisting analyses and to assess whether additional COCs should be added to the routine ERDF groundwater monitoring program. Separate leachate sampling is also performed to verify that waste acceptance criteria for the 
ETF are met prior to the transfer of leachate to that facility. The evaluation and reporting of the ETF sampling data is outside the scope of this report.

A composite sample of leachate media was collected in duplicate from the sumps (cells 1 through 4) associated with the upper landfill liners. The composite samples consist of equal quantities of material taken from each of the four sumps associated with the upper liners.

Initial leachate sampling (through the end of CY 2000) was performed quarterly for an extensive list of analytes as defined by the ERDF Amended ROD (EPA 1999, 2003). This "long list" of analytes is shown in Table C-2 in Appendix C. At the end of the initial baseline sampling, the analyte list was revised (short list), and leachate sampling was reduced to a semiannual basis. The short list of analytes is identified in Table C-1 of Appendix C. Once every 2 years, sampling of the long list of analytes is performed on the leachate as identified in the ERDF Amended ROD (EPA 1999, 2003).

The ERDF project continued routine sampling and analysis of landfill leachate during CY 2006. Composite leachate samples for the short list of analytes were collected during the June event and the long list was collected during the December monitoring event. Data for the current year and from the two prior years of leachate sampling (i.e., CYs 2004 to 2006) are used to identify trends that may indicate if additional laboratory analysis for groundwater samples is warranted.

\subsection{GROUNDWATER LEVELS}

Water-level measurements were collected from each of the four monitoring wells during the semiannual groundwater sampling events to determine groundwater accessibility during future monitoring events. Water-level measurements are taken during each routine groundwater monitoring event immediately prior to purging the well for sample collection.

During the September 2005 monitoring event the exact water level in monitoring well 699-36-67 could not be determined because the electronic tape measure (e-tape) did not appear to reach the top of the water in the well. The water level measuring device apparently did not sound indicating that water had been reached and appeared to be dry when removed from the well. Based on the length of the e-tape used, the water level in this well was more than $3.5 \mathrm{~m}(11.5 \mathrm{ft})$ lower than anticipated. Sampling at this well took place as planned, and the well produced a sufficient amount of water for sample collection. This measurement was treated as an anomaly and not used to evaluate water levels and future accessibility. Subsequent samples have returned to expected levels for this well.

Based on a water table map (Figure 3-1), groundwater in the vicinity of the ERDF generally moves from the west across the site to the east-northeast. The hydraulic gradient is about $0.001 \mathrm{~m} / \mathrm{m}(0.011 \mathrm{ft} / \mathrm{ft})(\mathrm{BHI} 1995)$. The groundwater table in and near the 200 West Area has been steadily declining since discharges to the 200 West Area pond and trench systems were discontinued during the mid-1980s.

The current hydrograph for the ERDF monitoring wells presented in Figure 3-2 indicates an annual decline of less than $0.4 \mathrm{~m} / \mathrm{yr}(1.31 \mathrm{ft} / \mathrm{yr})$, which is consistent with the regional hydrologic changes reported for the area (Swanson et al. 1999, Hartman et al. 2005). 
Figure 3-1. Water-Level Contour Map.

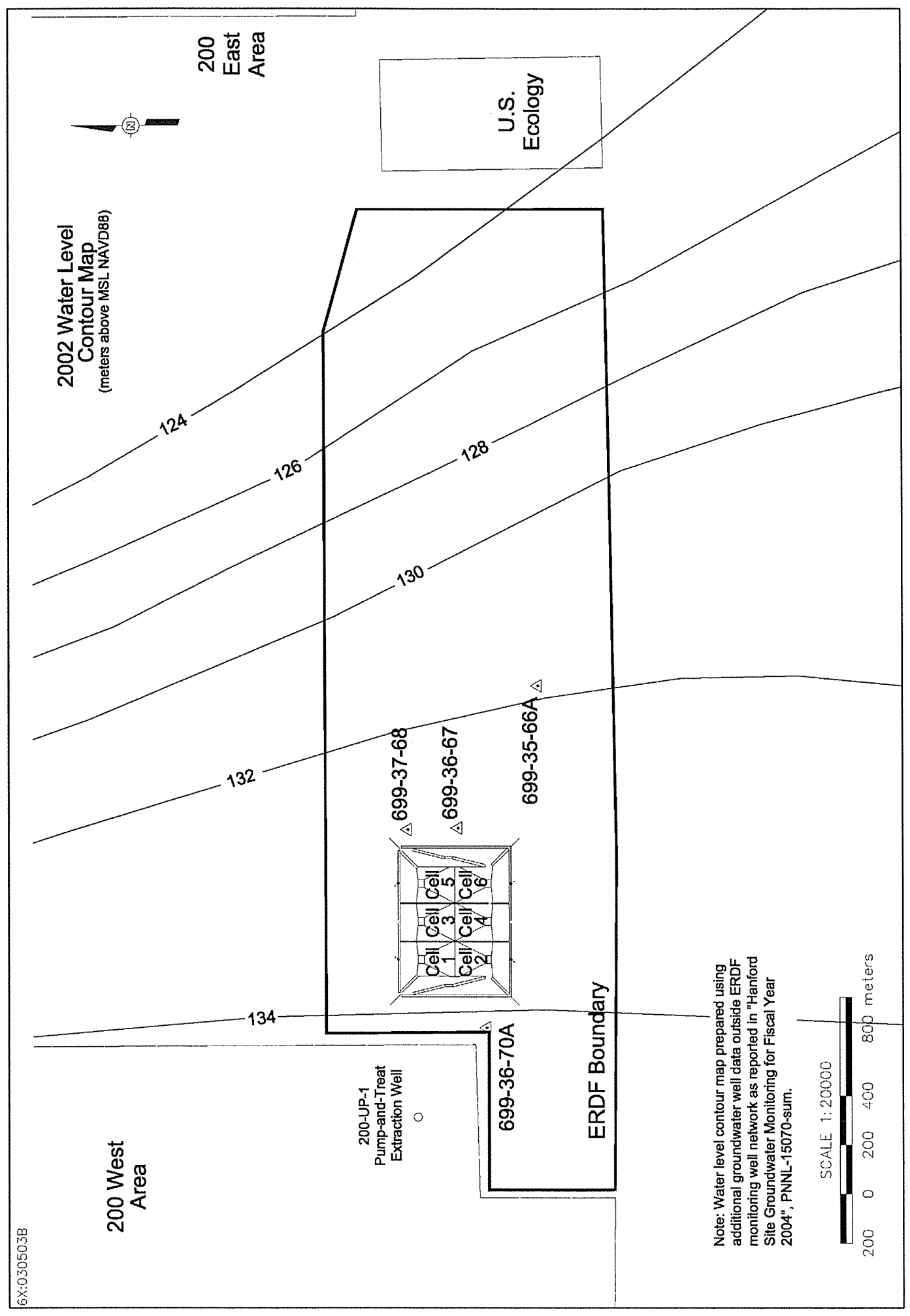


Figure 3-2. Hydrograph from ERDF Groundwater Monitoring Wells.

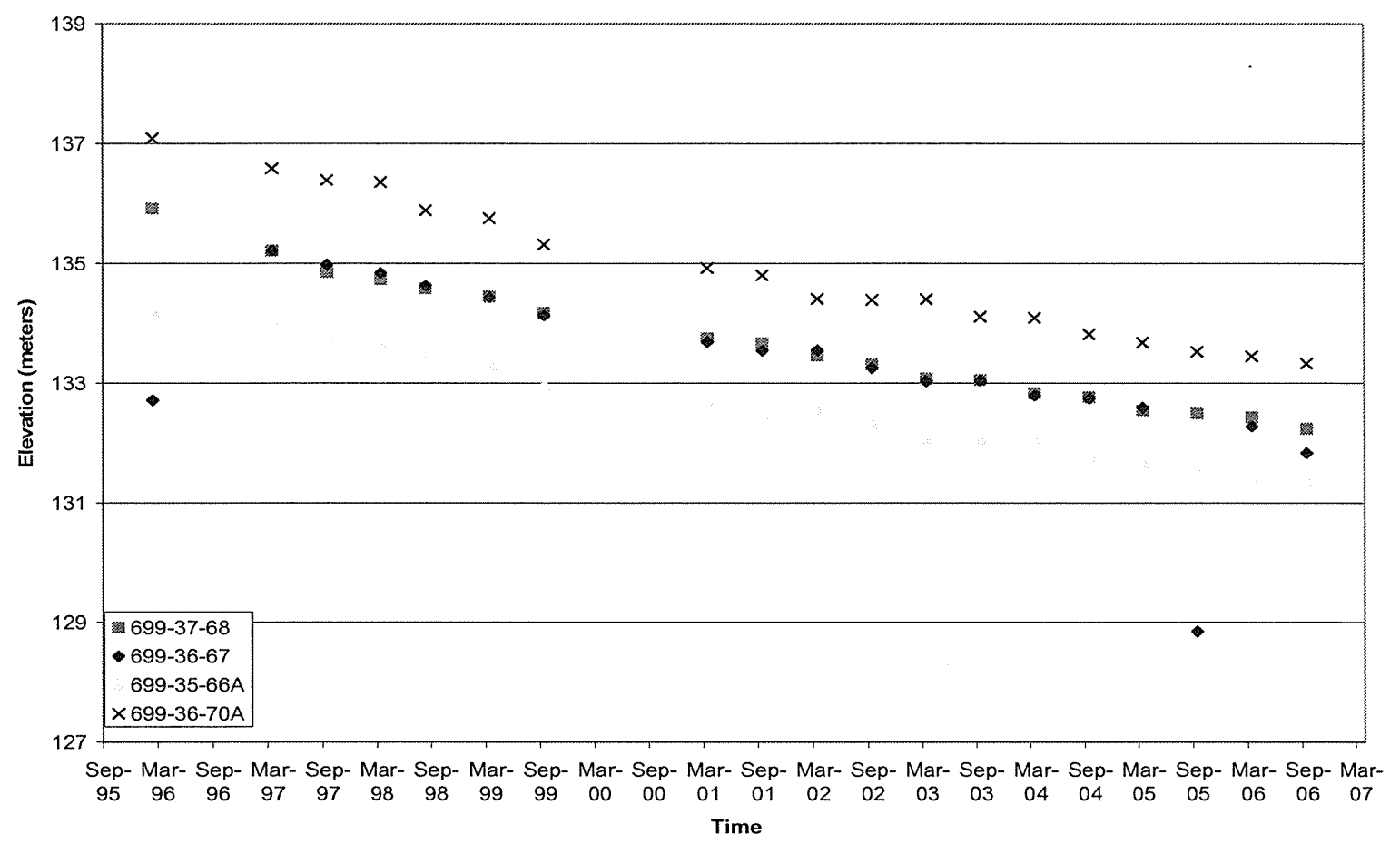




\subsection{ANALYTICAL RESULTS AND FIELD DATA}

Analytical results for leachate and groundwater samples collected during CY 2006 are discussed in the following subsections. Also discussed are the data resulting from CY 2006 groundwater-level measurements.

\subsection{SUMMARY OF GROUNDWATER ANALYSES}

The groundwater results were used to measure analytical and statistical variability. The statistical basis for comparison of the groundwater analysis results is presented in Section 3.1.2 of this report. Analytical results reported for groundwater samples collected from the ERDF monitoring well network are presented in Appendix $A$, and analyte trend plots summarizing groundwater monitoring results are included in Appendix $B$.

Groundwater monitoring results and apparent trends based on CY 2006 data are summarized in Table 4-1.

Due to a sample collection error, groundwater was not analyzed from any of the ERDF monitoring wells for the analysis of arsenic, lead, selenium, or tin during the March CY 2006 groundwater monitoring events. When this omission was discovered, since archive materials had already been disposed of, no reanalysis was possible. An attempt was made to obtain data for these analytes from the raw inductively coupled plasma metals data for other metals analysis. Unfortunately, no usable results could be recovered by the laboratory for these metals for this sampling event.

Table 4-1. Summary of Tolerance Interval Comparisons and Trends. (4 Pages)

\begin{tabular}{|c|c|c|c|c|c|c|}
\hline \multirow[t]{2}{*}{ Analyte } & \multirow{2}{*}{$\begin{array}{l}\text { Upper } \\
\text { Tolerance } \\
\text { Interval }\end{array}$} & \multicolumn{4}{|c|}{$\begin{array}{l}\text { Well(s) Exceeding Upper } \\
\text { Tolerance Interval } \\
\text { in CY } 2006^{\mathrm{a}}\end{array}$} & \multirow[t]{2}{*}{ Comments } \\
\hline & & $70 A$ & $66 \mathrm{~A}$ & 67 & 68 & \\
\hline Arsenic & $4.4 \mu \mathrm{g} / \mathrm{L}$ & Yes & Yes & No & No & $\begin{array}{l}\text { No data was recovered for the March } 2006 \text { sampling } \\
\text { due to a sampling error. Values from the } \\
\text { September } 2006 \text { sampling indicates that arsenic } \\
\text { appears to be trending upward in all wells (including } \\
\text { the upgradient well). This appears to be a long term } \\
\text { uptrend. It should also be noted that the reported } \\
\text { arsenic detects for CY } 2006 \text { remained below the } \\
\text { Hanford Site background levels for arsenic ( } 7.5 \mathrm{ppb}) \text {. }\end{array}$ \\
\hline Barium & $123.3 \mu \mathrm{g} / \mathrm{L}$ & No & No & No & No & $\begin{array}{l}\text { All wells exhibited concentrations below the tolerance } \\
\text { interval, stable with regards to previous years. }\end{array}$ \\
\hline Chromium & $16.5 \mu \mathrm{g} / \mathrm{L}$ & No & No & No & No & $\begin{array}{l}\text { All wells exhibited concentrations below the tolerance } \\
\text { interval, stable with regards to previous years. } \\
\text { Chromium levels in } 66 \mathrm{~A} \text { remain elevated relative to the } \\
\text { other wells near the upper tolerance limit }\end{array}$ \\
\hline
\end{tabular}


Table 4-1. Summary of Tolerance Interval Comparisons and Trends. (4 Pages)

\begin{tabular}{|c|c|c|c|c|c|c|}
\hline \multirow[t]{2}{*}{ Analyte } & \multirow{2}{*}{$\begin{array}{l}\text { Upper } \\
\text { Tolerance } \\
\text { Interval }\end{array}$} & \multicolumn{4}{|c|}{$\begin{array}{l}\text { Well(s) Exceeding Upper } \\
\text { Tolerance Interval } \\
\text { in CY } 2006^{\mathrm{a}}\end{array}$} & \multirow[t]{2}{*}{ Comments } \\
\hline & & $70 \mathrm{~A}$ & $66 \mathrm{~A}$ & 67 & 68 & \\
\hline Lead & $70.4 \mu \mathrm{g} / \mathrm{L}$ & No & No & No & No & $\begin{array}{l}\text { No data was recovered for the March } 2006 \text { sampling } \\
\text { due to a sampling error. Values from the } \\
\text { September } 2006 \text { sampling are below the tolerance } \\
\text { interval, consistent with previous analyses and appear } \\
\text { very stable. Validation flagged the low-level detect for } \\
\text { well } 66 \mathrm{~A} \text { as a nondetect due to low-level laboratory } \\
\text { contamination. }\end{array}$ \\
\hline Selenium & $5.6 \mu \mathrm{g} / \mathrm{L}$ & No & No & No & No & $\begin{array}{l}\text { No data was recovered for the March } 2006 \text { sampling } \\
\text { due to a sampling error. The values from the } \\
\text { September } 2006 \text { sampling are below the tolerance } \\
\text { interval, consistent with previous analyses, and appear } \\
\text { very stable. }\end{array}$ \\
\hline Tin & $55.6 \mu \mathrm{g} / \mathrm{L}$ & No & No & No & No & $\begin{array}{l}\text { No data was recovered for the March } 2006 \text { sampling } \\
\text { due to a sampling error. The values from the } \\
\text { September } 2006 \text { sampling are below the tolerance } \\
\text { interval, consistent with previous analyses and appear } \\
\text { very stable. }\end{array}$ \\
\hline Uranium & $3.4 \mu \mathrm{g} / \mathrm{L}$ & No & No & No & No & $\begin{array}{l}\text { All wells exhibited stable concentrations below the } \\
\text { tolerance interval. This element may be downward } \\
\text { trending in most wells. }\end{array}$ \\
\hline Vanadium & $41.0 \mu \mathrm{g} / \mathrm{L}$ & No & No & No & No & $\begin{array}{l}\text { All wells exhibited concentrations below the tolerance } \\
\text { interval, stable with regards to previous years. }\end{array}$ \\
\hline Zinc & $757 \mu \mathrm{g} / \mathrm{L}$ & No & No & No & No & $\begin{array}{l}\text { Well } 67 \text { continued to exhibit stable but elevated } \\
\text { concentrations relative to the other three wells, } \\
\text { apparently as a continuing impact of galvanic corrosion } \\
\text { to well components in previous years. Validation of } \\
\text { CY05 and CY06 data indicates that all low-level zinc } \\
\text { detects should be flagged as nondetect due to } \\
\text { laboratory contamination. }\end{array}$ \\
\hline Alkalinity & $151.8 \mathrm{mg} / \mathrm{L}$ & No & No & No & No & $\begin{array}{l}\text { All wells exhibited concentrations below the tolerance } \\
\text { interval, stable with regards to previous years. }\end{array}$ \\
\hline Chloride & $25.9 \mathrm{mg} / \mathrm{L}$ & No & No & No & No & $\begin{array}{l}\text { All wells exhibited concentrations below the upper } \\
\text { tolerance interval. The lower tolerance interval was } \\
\text { exceeded in well } 66 \mathrm{~A} \text { for both sampling events and for } \\
\text { well } 70 \mathrm{~A} \text { for the September } 2006 \text { sampling event. } \\
\text { These wells appear to be stabilizing at lower chloride } \\
\text { concentration levels than originally measured. All } \\
\text { other wells appear to be stable with regards to } \\
\text { previous years. }\end{array}$ \\
\hline Fluoride & $0.5 \mathrm{mg} / \mathrm{L}$ & No & No & No & No & $\begin{array}{l}\text { All wells exhibited concentrations below the tolerance } \\
\text { interval, stable with regards to previous years. }\end{array}$ \\
\hline Sulfate & $37.8 \mathrm{mg} / \mathrm{L}$ & No & No & No & No & $\begin{array}{l}\text { All wells exhibited concentrations below the tolerance } \\
\text { interval, stable with regards to previous years with an } \\
\text { indication of downtrending concentrations in all wells. }\end{array}$ \\
\hline
\end{tabular}


Table 4-1. Summary of Tolerance Interval Comparisons and Trends. (4 Pages)

\begin{tabular}{|c|c|c|c|c|c|c|}
\hline \multirow[t]{2}{*}{ Analyte } & \multirow{2}{*}{$\begin{array}{l}\text { Upper } \\
\text { Tolerance } \\
\text { Interval }\end{array}$} & \multicolumn{4}{|c|}{$\begin{array}{l}\text { Well(s) Exceeding Upper } \\
\text { Tolerance Interval } \\
\text { in CY } 2006^{\mathrm{a}}\end{array}$} & \multirow[t]{2}{*}{ Comments } \\
\hline & & $70 \mathrm{~A}$ & $66 \mathrm{~A}$ & 67 & 68 & \\
\hline Gross alpha & $3.3 \mathrm{pCi} / \mathrm{L}$ & No & No & No & No & $\begin{array}{l}\text { All wells exhibited concentrations below the tolerance } \\
\text { interval, stable with regards to previous years. Note } \\
\text { that the majority of the results are nondetected values, } \\
\text { which will show greater variability due to associated } \\
\text { counting statistics. }\end{array}$ \\
\hline Gross beta & $31.7 \mathrm{pCi} / \mathrm{L}$ & No & Yes & No & Yes & $\begin{array}{l}\text { Gross beta concentrations appear to be stabilizing or } \\
\text { downtrending at concentrations near to or above the } \\
\text { upper tolerance interval. Maximum values in } \\
\text { downgradient wells remained below previously } \\
\text { determined maximums in the upgradient well. The } \\
\text { gross beta activity appears to be associated with a } \\
\text { non-ERDF source(s). }\end{array}$ \\
\hline Carbon-14 & $26.8 \mathrm{pCi} / \mathrm{L}$ & No & Yes & No & No & $\begin{array}{l}\text { Carbon-14 was not detected in any of the wells during } \\
\text { the } 2006 \text { monitoring events; however, the detection } \\
\text { limits exceeded the upper tolerance interval for all } \\
\text { wells. The analytical detection limits all were less than } \\
\text { one-half of the required detection limit for this isotope. } \\
\text { Reported nondetect values exceeded the upper } \\
\text { tolerance interval for well } 66 \mathrm{~A} \text {, and the reported } \\
\text { nondetect result for well } 70 \mathrm{~A} \text { exceeded the lower } \\
\text { tolerance interval for the March } 2006 \text { sampling. } \\
\text { Nondetected values will show greater variability due to } \\
\text { associated counting statistics. }\end{array}$ \\
\hline lodine-129 & 21.5 pCi/L & No & No & No & No & $\begin{array}{l}\text { All wells exhibited concentrations below the tolerance } \\
\text { interval, stable with regards to previous years. }\end{array}$ \\
\hline Radium & $0.5 \mathrm{pCi} / \mathrm{L}$ & No & No & No & No & $\begin{array}{l}\text { Radium was not detected in any of the wells during the } \\
2006 \text { monitoring events; all detection limits were below } \\
\text { the upper tolerance interval all wells. Reported values } \\
\text { exceeded the lower tolerance interval for wells } 66 \mathrm{~A} \\
\text { and } 70 \mathrm{~A} \text { for both sampling events. Nondetected } \\
\text { values will show greater variability due to associated } \\
\text { counting statistics. }\end{array}$ \\
\hline $\begin{array}{l}\text { Technetium- } \\
99\end{array}$ & $94.9 \mathrm{pCi} / \mathrm{L}$ & No & No & No & No & $\begin{array}{l}\text { All wells exhibited concentrations below the tolerance } \\
\text { interval, with an indication of downtrending } \\
\text { concentrations in wells } 67 \text { and } 70 \mathrm{~A} \text {. }\end{array}$ \\
\hline $\begin{array}{l}\text { Carbon } \\
\text { tetrachloride }\end{array}$ & $10.6 \mu \mathrm{g} / \mathrm{L}$ & No & No & No & No & $\begin{array}{l}\text { All wells exhibited concentrations below the tolerance } \\
\text { interval with no significant trends identified. }\end{array}$ \\
\hline $\begin{array}{l}\text { Total organic } \\
\text { halides (TOX) }\end{array}$ & $9.5 \mu \mathrm{g} / \mathrm{L}$ & No & Yes & No & Yes & $\begin{array}{l}\text { All wells exhibited stable concentrations except for well } \\
68 \text { and well } 66 \text { A during September } 06 \text { exceeding the } \\
\text { upper tolerance level. TOX values that "spike" } \\
\text { unaccountably have been seen in past analyses and } \\
\text { have always followed by more typical values in the } \\
\text { next analysis round. This analysis should be } \\
\text { monitored in future rounds. Well } 68 \text { also slightly } \\
\text { exceeded the upper tolerance limit in the March } 2006 \\
\text { sampling. }\end{array}$ \\
\hline $\begin{array}{l}\text { Nitrogen in } \\
\text { nitrite and } \\
\text { nitrate }\end{array}$ & $51.5 \mathrm{mg} / \mathrm{L}$ & No & No & No & No & $\begin{array}{l}\text { All wells exhibited concentrations below the tolerance } \\
\text { interval, stable with regards to previous years with an } \\
\text { indication of downtrending concentrations in all wells. }\end{array}$ \\
\hline
\end{tabular}


Table 4-1. Summary of Tolerance Interval Comparisons and Trends. (4 Pages)

\begin{tabular}{|l|c|c|c|c|c|l|}
\hline \multirow{2}{*}{ Analyte } & \multirow{2}{*}{$\begin{array}{c}\text { Upper } \\
\text { Tolerance } \\
\text { Interval }\end{array}$} & \multicolumn{3}{|c|}{$\begin{array}{c}\text { Well(s) Exceeding Upper } \\
\text { Tolerance Interval } \\
\text { in CY 2006 }\end{array}$} & \multicolumn{1}{c|}{ Comments } \\
\cline { 3 - 6 } & $70 \mathrm{~A}$ & $66 \mathrm{~A}$ & 67 & 68 & \\
\hline $\begin{array}{l}\text { Total } \\
\text { dissolved } \\
\text { solids }\end{array}$ & $573.6 \mathrm{mg} / \mathrm{L}$ & No & No & No & No & $\begin{array}{l}\text { All wells exhibited stable concentrations below the } \\
\text { tolerance interval. }\end{array}$ \\
\hline $\begin{array}{l}\text { Specific } \\
\text { conductance }\end{array}$ & $743.3 \mu \mathrm{S} / \mathrm{m}$ & No & No & No & No & $\begin{array}{l}\text { All wells exhibited concentrations below the tolerance } \\
\text { interval, stable with regards to previous years. }\end{array}$ \\
\hline pH & $8.0 \mathrm{units}$ & No & No & No & No & $\begin{array}{l}\text { All wells exhibited concentrations below the tolerance } \\
\text { interval, stable with regards to previous years. }\end{array}$ \\
\hline Turbidity & $50 \mathrm{NTU}$ & No & No & No & No & $\begin{array}{l}\text { All wells exhibited concentrations below the tolerance } \\
\text { interval, stable with regards to previous years. }\end{array}$ \\
\hline
\end{tabular}

a Well identification:

$70 \mathrm{~A}=$ upgradient monitoring well 699-36-70A

$66 \mathrm{~A}=$ downgradient monitoring well 699-35-66A

67 = downgradient monitoring well 699-36-67

68 = downgradient monitoring well 699-37-68

$\mathrm{CY}=$ calendar year

Numerous contaminant plumes that originated from past activities in the 200 West Area are near or beneath the ERDF site. Chemical processing activities of uranium and plutonium in the 200 West Area are known to have introduced contaminants in the groundwater upgradient from ERDF. Plumes originating from 200 West Area sources detected in ERDF monitoring wells include nitrogen (nitrate plus nitrite), carbon tetrachloride, gross alpha, gross beta, technetium-99, iodine-129, and uranium. Detailed descriptions of the sources for these constituents are contained in the ERDF GPP (BHI 1996). The apparent trends in groundwater concentrations of these constituents are as follows:

- Nitrogen. Reported concentrations for nitrogen (nitrate plus nitrite) have remained fairly stable but show a very long-term downward trend for wells 699-36-67, 699-36-70A, and 699-37-68.

- Carbon Tetrachloride. Carbon tetrachloride concentrations have remained fairly consistent at levels below the upper tolerance interval within the ERDF monitoring wells.

- Gross Alpha Activity. Gross alpha activity concentrations have been slightly variable but generally within the calculated tolerance intervals since monitoring at the ERDF well network was initiated. Most recent samples have reported nondetect values.

- Gross Beta Activity. Activity concentrations for gross beta appear to have generally increased since monitoring of the ERDF wells was initiated in 1996. Recent samples suggest that gross beta activity may be stabilizing with some wells entering a downward trend.

- Technetium-99. Technetium-99 activity concentrations in the ERDF monitoring wells have remained fairly consistent and have generally been within tolerance intervals since 
monitoring was initiated in CY 1996. Recent samples suggest that activity has peaked in two wells and may be entering a downward trend.

- lodine-129. lodine-129 activity concentrations have remained fairly stable in all monitoring wells over the course of ERDF monitoring activities, and no wells have exceeded the upper tolerance interval.

- Uranium. Uranium concentrations in groundwater have generally been stable in the ERDF monitoring wells. Recent samples suggest that activity has peaked in most wells and may be entering a downward trend.

Downgradient well 699-36-67 continues to exhibit elevated zinc concentrations that are below the upper tolerance interval. The zinc concentrations in this well, and previously in well 699-37-68, were attributed to galvanic corrosion of the galvanized riser pipe with sampling pump equipment (BHI 2003, 2004, 2005b; WCH 2006). Monitoring well 699-36-67 has not been modified to remedy this issue, and the continued elevated zinc concentration in well 699-36-67 suggests that galvanic corrosion of the pumping equipment may be continuing. This well will be decommissioned and removed in late CY 2007 to allow for the next ERDF cell expansion. The replacement well should eliminate this zinc contamination issue. However, the tolerance interval for zinc should be recalculated after the new well is used.

\subsection{SUMMARY OF LEACHATE ANALYSIS}

Data associated with leachate sampling conducted from CY 2004 through CY 2006 are presented in Appendix C. Only analytical results that were reported as significant detects $(>1 \mathrm{ppb})$ or that were reported as nondetected values but which are on the routine short list or groundwater monitoring $\mathrm{COC}$ lists are included in this report.

Leachate samples contained detectable concentrations of common metals, anions, and mobile radionuclides. Constituents that were generally increasing in concentration include chromium, potassium, specific conductance, bromide, nitrate, gross alpha, and total uranium. The following is a summary of those analytes for which concentrations appear to be increasing:

- Chromium. Chromium concentrations that were previously slowly increasing at a stable rate over time appear to have stabilized.

- Nickel. Nickel, which is on the long list of analytes and is monitored once every 2 years, appears to be increasing in concentration.

- Potassium. Potassium, which is on the long list of analytes and is monitored once every 2 years, appeared to be increasing in concentration based on data collected during CY 2004. The results of the CY 2006 analysis show stable concentrations.

- Specific Conductance. Specific conductance appeared to remain stable until December 2004, at which time a fairly significant increase was observed. During June 2005 the specific conductance value remained high and decreased slightly during December 2005. The June 2006 values remained stable with the previous December samples, but the values increased again to similar maximums seen in December 2004. 
- Bromide. Bromide was not detected in leachate samples until June 2004 , and the concentration of bromide generally appeared to be increasing through June 2005. Data from the December 2005 monitoring event indicates that bromide concentrations may have either leveled off or may be decreasing. The most recent sampling indicates no real changes in the bromide concentrations. They remain near analytical detection limits.

- Nitrate. Nitrate concentrations had increased at a fairly steady rate through CY 2004 but appear to have dropped back to lower concentrations during CY 2005. Concentrations have remained stable though CY 2006.

- Total Dissolved Solids. Total dissolves solids are indicating a slight upward trend through the end of CY 2006. Continuing monitoring will be necessary to determine if a trend exists.

- Gross Alpha. Gross alpha activity concentrations have generally increased over the past 3 years.

- Gross Beta. Gross beta activity concentrations have generally increased over the past 3 years. The most recent results are comparable to the previous peak activity seen in the December 2002 samples.

- Uranium. Uranium activity concentrations have generally increased over the past 3 years and have reached a new maximum concentration.

\subsection{SUMMARY OF WATER-LEVEL MEASUREMENTS}

Groundwater monitoring wells in the ERDF well network have exhibited a gradual rate of decline in water levels since monitoring was initiated in September 1996. Water-level measurements collected during CY 2006 from wells 699-36-67, 699-37-68, 699-35-66A, and 699-36-70A show a rate of decline that is consistent with recent previous years.

Based on the measured water levels in the four ERDF monitoring wells, it was determined that

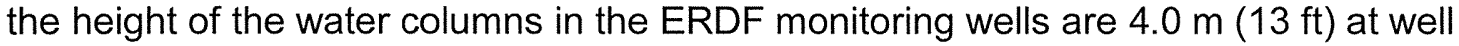
699-35-66A, $4.9 \mathrm{~m}(16 \mathrm{ft})$ of water at well 699-36-70A, $5.0 \mathrm{~m}(16 \mathrm{ft})$ of water at well 699-36-67,

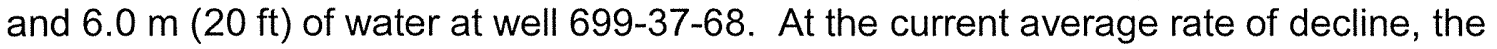
monitoring wells would be available for use, as they are currently constructed, for approximately 15 to 22 years.

Wells 699-36-67 and 699-37-68 will be decommissioned and removed in late CY 2007 to allow for the ERDF expansion. Replacement wells will be put in place. 


\subsection{CONCLUSIONS AND RECOMMENDATIONS}

Based on the CY 2006 analytical results, the statistical analysis of monitoring data, an evaluation of leachate monitoring data, and a review of the water-level measurement data, the following conclusions and recommendations are presented.

Nitrogen, carbon tetrachloride, gross beta, technetium-99, iodine-129, and uranium present in samples collected from the ERDF monitoring wells are due to the migration of contaminants from non-ERDF sources in the 200 West Area.

Analytical results for arsenic and total organic halides need to be monitored closely in future analytical events. Although arsenic concentrations remain well below Hanford Site background reference values, concentrations may be trending upward. No Hanford Site-derived sources for arsenic have been identified for potential impact in the groundwater under ERDF. Pre-Hanford Site use of arsenic in agriculture may be the source of the contamination seen.

Total organic halide analysis has shown periodic spikes in the groundwater data in the past. This includes the upgradient well and reported results returned below the control limits in the next sampling events. No correlations can be seen between total organic halide results and the volatile organic analyses (VOA) performed at the same time (VOA will report unexpected detections of chlorinated organics, the most likely contributor to total organic halide results). Total organic halide analysis is only an indicator analysis. Any future indication of consistent contamination must be monitored closely to establish the source and composition of the compounds.

Trends indicating increasing concentrations of nickel, gross alpha, gross beta, and uranium were noted for leachate samples collected over the past 3 years. Groundwater monitoring data for these constituents were examined to determine potential impacts to groundwater from ERDF operations. In all cases, groundwater concentrations for these constituents have remained stable, and it appears that ERDF leachate has not negatively impacted groundwater at this location. At this time, no additional analytes are recommended for the groundwater monitoring program based on this evaluation.

No additional analysis is necessary for the routine leachate sampling given that the groundwater and leachate sampling conducted to date does not indicate potential impacts to the groundwater from ERDF operations.

Replacement wells should be drilled to sufficient depth to minimize potential impacts as the groundwater levels continue to decrease with time.

The removal of the zinc contamination source associated with well 699-36-67 will require reevaluation of an appropriate tolerance interval for this element. Other elements may also be affected in an "step change" fashion and be require that other tolerance intervals be revaluated as well.

The current groundwater sampling frequency appears to be appropriate for future monitoring needs. 


\subsection{REFERENCES}

BHI, 1995, Preoperational Baseline and Site Characterization Report for the Environmental Restoration Disposal Facility, BHI-00270, Rev. 00, Bechtel Hanford, Inc., Richland, Washington.

BHI, 1996, Groundwater Protection Plan for the Environmental Restoration Disposal Facility, BHI-00079, Rev. 0, Bechtel Hanford, Inc., Richland, Washington.

BHI, 2002, Groundwater Monitoring and Sampling at the Environmental Restoration Disposal Facility, Calendar Year 2001, BHI-01641, Rev. 0, Bechtel Hanford Inc., Richland, Washington.

BHI, 2003, Groundwater and Leachate Monitoring and Sampling at the Environmental Restoration Disposal Facility, Calendar Year 2002, BHI-01684, Rev. 0, Bechtel Hanford Inc., Richland, Washington.

BHI, 2004, Groundwater and Leachate Monitoring and Sampling at the Environmental Restoration Disposal Facility, Calendar Year 2003, BHI-01738, Rev. 0, Bechtel Hanford Inc., Richland, Washington.

BHI, 2005a, Description of Work for Routine Groundwater Sampling at the Environmental Restoration Disposal Facility, BHI-00873, Rev. 1, Bechtel Hanford, Inc., Richland, Washington.

BHI, 2005b, Groundwater and Leachate Monitoring and Sampling at the Environmental Restoration Disposal Facility, Calendar Year 2004, BHI-01777, Rev. 0, Bechtel Hanford Inc., Richland, Washington.

Comprehensive Environmental Response, Compensation, and Liability Act of 1980 , 42 U.S.C. 9601 , et seq.

EPA, 19890, Prescribed Procedures for Measurement of Radioactivity in Drinking Water, EPA/600/4-80-032, U.S. Environmental Protection Agency, Washington, D.C.

EPA, 1986, Test Methods for Evaluating Solid Wastes: Physical Chemical Methods, SW-846, (supplemented 1990), U.S. Environmental Protection Agency, Washington, D.C.

EPA, 1995, Record of Decision for the Environmental Restoration Disposal Facility, Hanford Site, 200 Area, Benton County, Washington, U.S. Environmental Protection Agency, Region 10, Seattle, Washington.

EPA, 1999, Amended Record of Decision, Decision Summary and Responsiveness Summary for the Environmental Restoration Disposal Facility, Hanford Site - 200 Area, Benton County, Washington, U.S. Environmental Protection Agency, Region 10, Seattle, Washington. 
EPA, 2003, Amendment to the Record of Decision for the Environmental Restoration Disposal Facility, Hanford Site, 200 Area, Benton County, Washington, U.S. Environmental Protection Agency, Region 10, Seattle, Washington.

Faurote, J. M., 2000, Groundwater Monitoring and Sampling at the Environmental Restoration Disposal Facility, Calendar Year 1996 Through 1999, BHI-01382, Rev. 0, Bechtel Hanford, Inc., Richland, Washington.

Hartman, M. J., L. F. Morasch, and W. D. Webber (eds.), 2005, Summary of Hanford Site Groundwater Monitoring for Fiscal Year 2004, PNNL-15070-SUM, Pacific Northwest National Laboratory, Richland, Washington.

Kopp, J. F. and G. D. McKee, 1983, Methods for Chemical Analysis of Water and Wastes, EPA-600/4-79-020, U.S. Environmental Protection Agency, Environmental Monitoring and Support Laboratory, Washington, D.C.

Lindahl, P. C., 1984, Determination of Inorganic Anions in Aqueous and Solid Samples of Ion Chromatography, EPA/600/4-84/017, Argonne National Laboratory, Argonne, Illinois.

PNNL, 2000, Hanford Site Groundwater Monitoring Setting, Sources and Methods, PNNL-13080, Pacific Northwest National Laboratory, Richland, Washington.

Resource Conservation and Recovery Act of 1976, 42 U.S.C. 6901, et seq.

Swanson, L. C., V. J. Rohay, and J. M. Faurote, 1999, Hydrogeologic Conceptual Model for the Carbon Tetrachloride and Uranium/Technetium Plumes in the 200 West Area: 1994 Through 1999 Update, BHI-01311, Rev. 0, Bechtel Hanford, Inc., Richland, Washington.

WCH, 2006, Groundwater Monitoring and Sampling at the Environmental Restoration Disposal Facility, Calendar Year 2005, WCH-88, Rev. 0, Washington Closure Hanford, Richland, Washington. 


\section{APPENDIX A}

\section{GROUNDWATER SAMPLING RESULTS, 1996-2006}


WCH-189

Rev. 1

GW and Leachate Monitoring and Sampling at ERDF, CY 2006 
Table A-1. Arsenic Data.

\begin{tabular}{|c|c|c|c|c|c|c|c|c|c|c|c|c|c|c|}
\hline $\begin{array}{c}\text { Sample } \\
\text { Date }\end{array}$ & $\begin{array}{c}\text { 699-35-66A } \\
\text { (Down } \\
\text { Gradient) }\end{array}$ & Qual & DUP & $\begin{array}{l}\text { 699-36-67 } \\
\text { (Down } \\
\text { Gradient) }\end{array}$ & Qual & DUP & $\begin{array}{c}\text { 699-36-70A (Up } \\
\text { Gradient) }\end{array}$ & Qual & DUP & $\begin{array}{l}\text { 699-37-68 } \\
\text { (Down } \\
\text { Gradient) }\end{array}$ & Qual & DUP & $\begin{array}{l}\text { Upper } \\
\text { Limit }\end{array}$ & $\begin{array}{l}\text { Lower } \\
\text { Limit }\end{array}$ \\
\hline Mar-96 & 3 & B & & 1.1 & B & & 3 & B & & 1.7 & B & $1.7 \mathrm{~B}$ & 4.4 & -0.1 \\
\hline Sep-96 & 2.6 & B & $0.0038 \mathrm{~B}$ & 0.98 & $B$ & & 2.1 & B & & 0.67 & B & & 4.4 & -0.1 \\
\hline Mar-97 & 2.8 & $B$ & $2.7 \mathrm{~B}$ & 2 & B & & 2.5 & B & & 1.4 & B & & 4.4 & -0.1 \\
\hline Sep-97 & 3.5 & B & $2.8 \mathrm{~B}$ & 1.9 & B & & 3.3 & B & & 1.6 & U & & 4.4 & -0.1 \\
\hline Mar-98 & 2.1 & B & & 1.6 & B & $1.1 \mathrm{~B}$ & 2.6 & B & & 0.6 & u & & 4.4 & -0.1 \\
\hline Aug-98 & 2.8 & B & & 1 & U & & 1.2 & B & & 1.4 & B & $1 U$ & 4.4 & -0.1 \\
\hline Mar-99 & 3.3 & $U$ & & 3.3 & $U$ & $3.3 \mathrm{U}$ & 3.3 & $U$ & & 3.3 & U & & 4.4 & -0.1 \\
\hline Sep-99 & 3.3 & U & $3.3 \mathrm{U}$ & 3.3 & U & & 3.3 & U & & 3.3 & u & & 4.4 & -0.1 \\
\hline Mar-00 & & & & & & & & & & & & & 4.4 & -0.1 \\
\hline Sep-00 & 2.6 & & & 2.4 & $U$ & & 3.2 & & 3.8 & & & & 4.4 & -0.1 \\
\hline Mar-01 & 3 & & & 2.3 & $U$ & & 5.2 & & & 4.5 & & 3.2 & 4.4 & -0.1 \\
\hline Sep-01 & 5.6 & & & 22.8 & & $10 U$ & 52.1 & U & & 52.1 & U & & 4.4 & -0.1 \\
\hline Mar-02 & 4.4 & & $3 U$ & 4.6 & & & 4.3 & & & 3 & U & & 4.4 & -0.1 \\
\hline Sep-02 & 4.4 & & & 4.5 & $U$ & 3.3 & 3.8 & & & 3.3 & U & & 4.4 & -0.1 \\
\hline Mar-03 & 3.5 & U & & 4.4 & & & 3.5 & U & & 3.5 & U & & 4.4 & -0.1 \\
\hline Sep-03 & 4.2 & U & $4.2 \mathrm{U}$ & 4.2 & U & & 4.2 & U & & 4.2 & U & & 4.4 & -0.1 \\
\hline Mar-04 & 3.4 & $u$ & & 3.40 & $U$ & & 3.4 & $U$ & & 3.4 & $U$ & $3.4 U$ & 4.4 & -0.1 \\
\hline Sep-04 & 3.6 & $U$ & & 3.7 & & $3.6 \mathrm{U}$ & 3.6 & U & & 3.6 & U & & 4.4 & -0.1 \\
\hline Mar-05 & 34 & U & $34 \mathrm{U}$ & 34 & $U$ & & 34 & U & & 34 & $U$ & & 4.4 & -0.1 \\
\hline Sep-05 & 4.7 & U & & 23.6 & $U$ & & 23.6 & U & & 27.5 & & $23.6 \mathrm{U}$ & 4.4 & -0.1 \\
\hline Mar-06 & & & & & & & & & & & & & 4.4 & -0.1 \\
\hline Sep-06 & 5.3 & & & 3.7 & $U$ & $3.7 \mathrm{U}$ & 4.7 & & & 3.7 & $U$ & & 4.4 & -0.1 \\
\hline
\end{tabular}

NOTE: Values are in ug/L. 
Table A-2. Barium Data.

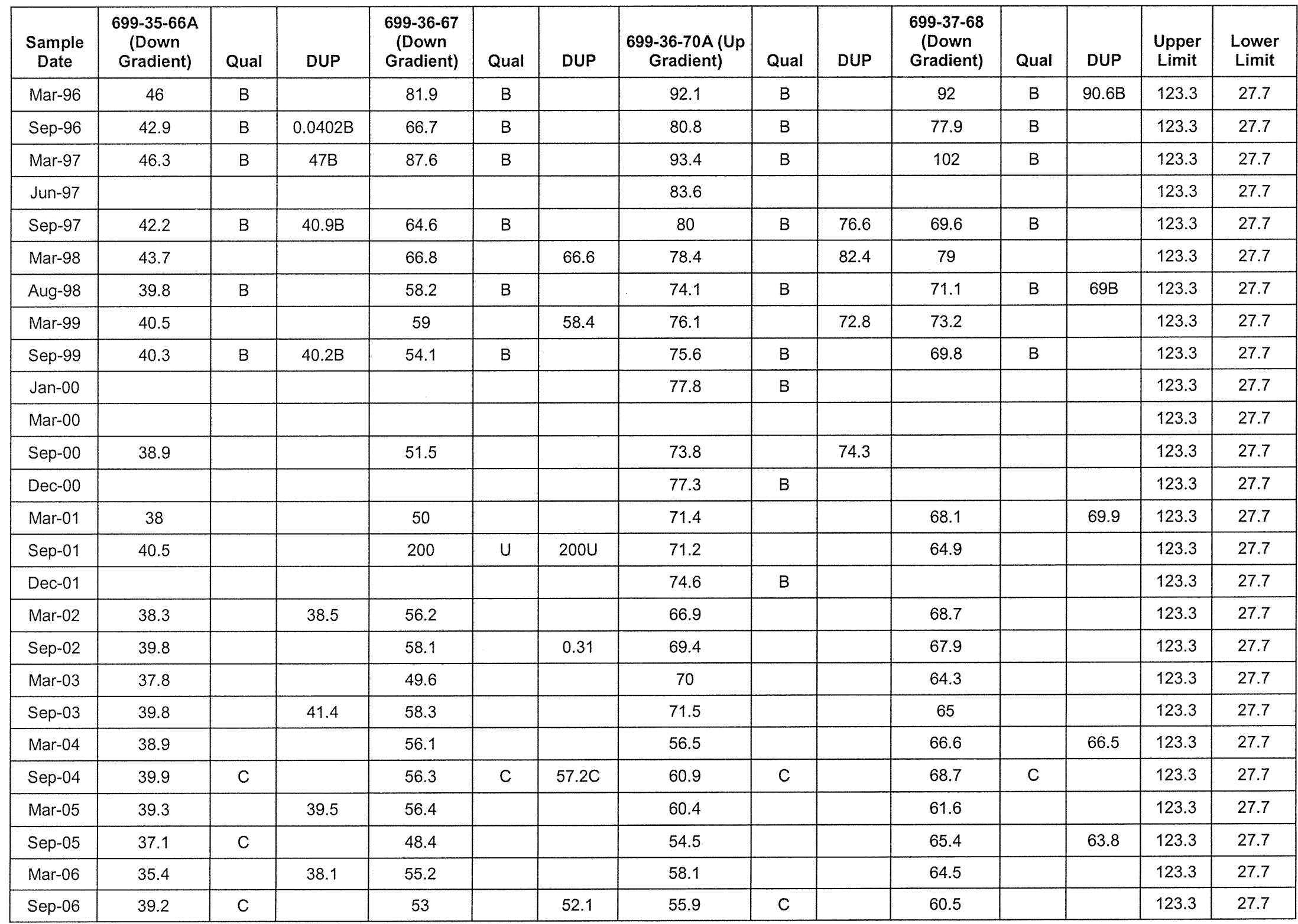


Table A-3. Chromium Data.

\begin{tabular}{|c|c|c|c|c|c|c|c|c|c|c|c|c|c|c|}
\hline $\begin{array}{l}\text { Sample } \\
\text { Date }\end{array}$ & $\begin{array}{c}\text { 699-35-66A } \\
\text { (Down } \\
\text { Gradient) }\end{array}$ & Qual & DUP & $\begin{array}{l}\text { 699-36-67 } \\
\text { (Down } \\
\text { Gradient) }\end{array}$ & Qual & DUP & $\begin{array}{c}\text { 699-36-70A (Up } \\
\text { Gradient) }\end{array}$ & Qual & DUP & $\begin{array}{c}\text { 699-37-68 } \\
\text { (Down } \\
\text { Gradient) }\end{array}$ & Qual & DUP & $\begin{array}{l}\text { Upper } \\
\text { Limit }\end{array}$ & $\begin{array}{l}\text { Lower } \\
\text { Limit }\end{array}$ \\
\hline Mar-96 & 13.4 & & & 4.4 & $U$ & & 5.9 & B & & 7.7 & B & $5.1 \mathrm{~B}$ & 16.5 & -3.6 \\
\hline Sep-96 & 12.1 & & 0.0205 & 4.4 & U & & 4.4 & $U$ & & 4.4 & $U$ & & 16.5 & -3.6 \\
\hline Mar-97 & 12.2 & & 12 & 2.7 & $U$ & & 3.9 & B & & 4.5 & $B$ & & 16.5 & -3.6 \\
\hline Jun-97 & & & & & & & 7.9 & B & & & & & 16.5 & -3.6 \\
\hline Sep-97 & 13.4 & & 13.3 & 3.3 & $B$ & & 3.5 & $U$ & $3.6 \mathrm{~B}$ & 3.5 & $U$ & & 16.5 & -3.6 \\
\hline Mar-98 & 16.6 & & & 3.3 & B & $3.6 \mathrm{~B}$ & 6.8 & B & $5.4 \mathrm{~B}$ & 4.1 & B & & 16.5 & -3.6 \\
\hline Aug-98 & 13.5 & & & 4.2 & U & & 4.2 & $U$ & & 4.2 & U & $4.2 U$ & 16.5 & -3.6 \\
\hline Mar-99 & 13.9 & & & 2.3 & 2.2 & & 6.1 & B & 2.2 & 3.1 & & & 16.5 & -3.6 \\
\hline Sep-99 & 14.8 & & 14.8 & 2.5 & B & & 4.4 & B & & 3.1 & $B$ & & 16.5 & -3.6 \\
\hline Jan-00 & & & & & & & 4.4 & B & & & & & 16.5 & -3.6 \\
\hline Mar-00 & & & & & & & & & & & & & 16.5 & -3.6 \\
\hline Sep-00 & 16.3 & & & 1.6 & & & 4.6 & & 4.9 & & & & 16.5 & -3.6 \\
\hline Dec-00 & & & & & & & 5.7 & U & & & & & 16.5 & -3.6 \\
\hline Mar-01 & 14.8 & & & 2.4 & & & 4.1 & & & 4.5 & & 3.8 & 16.5 & -3.6 \\
\hline Sep-01 & 21.1 & & & 10 & $U$ & $10 U$ & 7.4 & & & 5.4 & & & 16.5 & -3.6 \\
\hline Dec-01 & & & & & & & 1.5 & B & & & & & 16.5 & -3.6 \\
\hline Mar-02 & 16.3 & & 16.2 & 5.2 & & & 6 & & & 11.3 & & & 16.5 & -3.6 \\
\hline Sep-02 & 16.2 & & & 5.6 & & 1.2 & 5.5 & & & 8.7 & & & 16.5 & -3.6 \\
\hline Mar-03 & 16.3 & & & 2.5 & & & 3.8 & & & 9.9 & & & 16.5 & -3.6 \\
\hline Sep-03 & 16.2 & C & $17.2 \mathrm{C}$ & 3.6 & & & 4.9 & & & 12 & C & & 16.5 & -3.6 \\
\hline Mar-04 & 16.6 & & & 4.1 & & & 4 & & & 4.4 & & 3.8 & 16.5 & -3.6 \\
\hline Sep-04 & 15.6 & & & 5.5 & & 5.3 & 3.8 & & & 11.6 & & & 16.5 & -3.6 \\
\hline Mar-05 & 15.9 & & 17.1 & 9.7 & U & & 9.7 & $U$ & & 9.7 & $U$ & & 16.5 & -3.6 \\
\hline Sep-05 & 14.4 & & & 3.6 & UC & & 3.6 & UC & & 3.6 & UC & $5.4 \cup C$ & 16.5 & -3.6 \\
\hline Mar-06 & 14.6 & & 15.8 & 6.4 & U & 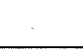 & 6.4 & U & & 6.4 & U & & 16.5 & -3.6 \\
\hline Sep-06 & 16.3 & & & 2.5 & & 2.6 & 4.8 & & & 3.4 & & & 16.5 & -3.6 \\
\hline
\end{tabular}


Table A-4. Lead Data.

\begin{tabular}{|c|c|c|c|c|c|c|c|c|c|c|c|c|c|c|}
\hline $\begin{array}{l}\text { Sample } \\
\text { Date }\end{array}$ & $\begin{array}{c}\text { 699-35-66A } \\
\text { (Down } \\
\text { Gradient) }\end{array}$ & Qual & DUP & $\begin{array}{l}\text { 699-36-67 } \\
\text { (Down } \\
\text { Gradient) }\end{array}$ & Qual & DUP & $\begin{array}{l}\text { 699-36-70A } \\
\text { (Up Gradient) }\end{array}$ & Qual & DUP & $\begin{array}{c}\text { 699-37-68 } \\
\text { (Down } \\
\text { Gradient) }\end{array}$ & Qual & DUP & $\begin{array}{l}\text { Upper } \\
\text { Limit }\end{array}$ & $\begin{array}{l}\text { Lower } \\
\text { Limit }\end{array}$ \\
\hline Mar-96 & 1 & UJ & & 1 & UJ & & 1 & UJ & & 1 & UJ & $1 \mathrm{UJ}$ & 70.4 & -28.5 \\
\hline Sep-96 & 42.1 & U & $0.002 \mathrm{U}$ & 42.1 & $U$ & & 42.1 & U & & 42.1 & $U$ & & 70.4 & -28.5 \\
\hline Mar-97 & 26 & $u$ & $26 U$ & 26 & $u$ & & 34.8 & $B$ & & 26 & $U$ & & 70.4 & -28.5 \\
\hline Sep-97 & 1.1 & U & $1.1 \mathrm{U}$ & 1.1 & $U$ & & 1.1 & $U$ & & 47.1 & $U$ & & 70.4 & -28.5 \\
\hline Mar-98 & 1.1 & $U$ & & 1.1 & $U$ & $1.1 \mathrm{U}$ & 1.1 & $u$ & & 2.4 & $B$ & & 70.4 & -28.5 \\
\hline Aug-98 & 30.2 & $U$ & & 30.2 & $U$ & & 30.2 & U & & 30.2 & $U$ & $30.2 U$ & 70.4 & -28.5 \\
\hline Mar-99 & 1.8 & $u$ & & 1.8 & $U$ & $1.8 \mathrm{U}$ & 1.8 & $U$ & & 2.5 & & & 70.4 & -28.5 \\
\hline Sep-99 & 2.1 & $U$ & 4 & 49.2 & & & 6.7 & & & 2.4 & B & & 70.4 & -28.5 \\
\hline Mar-00 & & & & & & & & & & & & & 70.4 & -28.5 \\
\hline Sep-00 & 2.1 & $U$ & & 2.1 & $U$ & & 2.1 & $U$ & $2.1 U$ & & & & 70.4 & -28.5 \\
\hline Mar-01 & 2.6 & U & & 2.6 & $U$ & & 2.6 & $U$ & & 2.6 & $U$ & $2.6 \mathrm{U}$ & 70.4 & -28.5 \\
\hline Sep-01 & 3.7 & & & 6.8 & & $3 U$ & 22.7 & U & & 22.7 & $u$ & & 70.4 & -28.5 \\
\hline Mar-02 & 2.2 & U & 2.8 & 2.2 & $U$ & & 2.2 & $U$ & & 4.2 & & & 70.4 & -28.5 \\
\hline Sep-02 & 2.4 & U & & 2.4 & $U$ & $2.4 U$ & 2.4 & $U$ & & 2.4 & $U$ & & 70.4 & -28.5 \\
\hline Mar-03 & 2.6 & U & & 2.3 & $U$ & & 2.6 & $U$ & & 2.6 & $U$ & & 70.4 & -28.5 \\
\hline Sep-03 & 1.9 & U & $1.9 \mathrm{U}$ & 1.9 & $U$ & & 1.9 & $U$ & & 1.9 & $U$ & & 70.4 & -28.5 \\
\hline Mar-04 & 2 & $U$ & & 2 & U & & 2 & U & & 2 & $U$ & 2 & 70.4 & -28.5 \\
\hline Sep-04 & 1.9 & U & & 1.9 & U & $1.9 \mathrm{U}$ & 1.9 & U & & 1.9 & U & & 70.4 & -28.5 \\
\hline Mar-05 & 24.7 & U & $24.7 \mathrm{U}$ & 24.7 & U & & 24.7 & U & & 24.7 & U & & 70.4 & -28.5 \\
\hline Sep-05 & 2.9 & U & & 31.9 & U & & 31.9 & U & & 31.9 & U & $31.9 \mathrm{U}$ & 70.4 & -28.5 \\
\hline Mar-06 & & & & & & & & & & & & & 70.4 & -28.5 \\
\hline Sep-06 & 3.3 & UC & & 1.2 & $U$ & $1.2 U$ & 1.2 & U & & 1.2 & $U$ & & 70.4 & -28.5 \\
\hline
\end{tabular}


Table A-5. Selenium Data.

\begin{tabular}{|c|c|c|c|c|c|c|c|c|c|c|c|c|c|c|}
\hline $\begin{array}{l}\text { Sample } \\
\text { Date }\end{array}$ & $\begin{array}{c}\text { 699-35-66A } \\
\text { (Down } \\
\text { Gradient) }\end{array}$ & Qual & DUP & $\begin{array}{c}\text { 699-36-67 } \\
\text { (Down } \\
\text { Gradient) }\end{array}$ & Qual & DUP & $\begin{array}{c}\text { 699-36-70A (Up } \\
\text { Gradient) }\end{array}$ & Qual & DUP & $\begin{array}{l}\text { 699-37-68 } \\
\text { (Down } \\
\text { Gradient) }\end{array}$ & Qual & DUP & $\begin{array}{l}\text { Upper } \\
\text { Limit }\end{array}$ & $\begin{array}{l}\text { Lower } \\
\text { Limit }\end{array}$ \\
\hline Mar-96 & 2.1 & B & & 2.6 & B & & 3.5 & $B$ & & 3.4 & B & $3.6 \mathrm{~B}$ & 5.6 & 1.5 \\
\hline Sep-96 & 3.1 & $B$ & $0.003 \mathrm{U}$ & 3.8 & B & & 4.1 & B & & 4.8 & B & & 5.6 & 1.5 \\
\hline Mar-97 & 2.6 & $\mathrm{BN}$ & $2.3 \mathrm{BN}$ & 3.5 & $\mathrm{BN}$ & & 3.1 & $\mathrm{BN}$ & & 3.9 & $\mathrm{BN}$ & & 5.6 & 1.5 \\
\hline Sep-97 & 3.2 & B & $2.9 \mathrm{~B}$ & 3.6 & B & & 4.8 & B & & 4.6 & B & & 5.6 & 1.5 \\
\hline Mar-98 & 3.2 & B & & 3.6 & B & $3.6 \mathrm{~B}$ & 4.4 & B & & 4.2 & B & & 5.6 & 1.5 \\
\hline Aug-98 & 3.2 & $B$ & & 4.5 & B & & 5.8 & & & 5.8 & & 5.5 & 5.6 & 1.5 \\
\hline Mar-99 & 5.2 & & & 3.6 & $U$ & 4.5 & 7.6 & & & 4.2 & & & 5.6 & 1.5 \\
\hline Sep-99 & 3.7 & U & 5.2 & 3.7 & U & & 7.3 & & & 4.6 & B & & 5.6 & 1.5 \\
\hline Mar-00 & & & & & & & & & & & & & 5.6 & 1.5 \\
\hline Sep-00 & 3.4 & & & 3.5 & & & 4 & & 5.5 & & & & 5.6 & 1.5 \\
\hline Mar-01 & 2.6 & $U$ & & 3.1 & & & 3.4 & & & 2.6 & & $2.6 \mathrm{U}$ & 5.6 & 1.5 \\
\hline Sep-01 & 5.9 & & & 5 & $U$ & 19.8 & 62.1 & U & & 62.1 & U & & 5.6 & 1.5 \\
\hline Mar-02 & 7.7 & & 7.9 & 3.6 & $U$ & & 7.8 & & & 7.7 & & & 5.6 & 1.5 \\
\hline Sep-02 & 4.1 & U & & 4.1 & $U$ & $4.1 \mathrm{U}$ & 7.4 & & & 4.1 & U & & 5.6 & 1.5 \\
\hline Mar-03 & 3.6 & $U$ & & 5.7 & & & 4.4 & $U$ & & 3.8 & $U$ & & 5.6 & 1.5 \\
\hline Sep-03 & 3.8 & & 4.4 & 3.6 & & & 6.9 & & & 5.7 & & & 5.6 & 1.5 \\
\hline Mar-04 & 4.2 & & & 5.6 & & & 7.4 & & & 3.4 & $U$ & $3.4 U$ & 5.6 & 1.5 \\
\hline Sep-04 & 3.9 & U & & 3.9 & $U$ & $3.9 \mathrm{U}$ & 3.9 & $U$ & & 3.9 & $U$ & & 5.6 & 1.5 \\
\hline Mar-05 & 48.5 & U & $48.5 \mathrm{U}$ & 48.5 & U & & 48.5 & U & & 48.5 & $U$ & & 5.6 & 1.5 \\
\hline Sep-05 & 6.2 & $\mathrm{C}$ & & 44 & $U$ & & 44 & U & & 44 & $U$ & $44.0 \mathrm{U}$ & 5.6 & 1.5 \\
\hline Mar-06 & & & & & & & & & & & & & 5.6 & 1.5 \\
\hline Sep-06 & 4.4 & & & 3.3 & & 5.2 & 3.7 & & & 3 & & & 5.6 & 1.5 \\
\hline
\end{tabular}


Table A-6. Uranium Data.

\begin{tabular}{|c|c|c|c|c|c|c|c|c|c|c|c|c|c|c|}
\hline $\begin{array}{l}\text { Sample } \\
\text { Date }\end{array}$ & $\begin{array}{c}\text { 699-35-66A } \\
\text { (Down } \\
\text { Gradient) }\end{array}$ & Qual & DUP & $\begin{array}{l}\text { 699-36-67 } \\
\text { (Down } \\
\text { Gradient) }\end{array}$ & Qual & DUP & $\begin{array}{c}\text { 699-36-70A } \\
\text { (Up Gradient) }\end{array}$ & Qual & DUP & $\begin{array}{l}\text { 699-37-68 } \\
\text { (Down } \\
\text { Gradient) }\end{array}$ & Qual & DUP & $\begin{array}{l}\text { Upper } \\
\text { Limit }\end{array}$ & $\begin{array}{l}\text { Lower } \\
\text { Limit }\end{array}$ \\
\hline Sep-95 & & & & & & & 2.98 & U & & & & & 3.4 & 1.9 \\
\hline Mar-96 & 2.64 & & & 2.24 & & & 2.94 & & & 2.74 & & 2.77 & 3.4 & 1.9 \\
\hline Sep-96 & 2.4 & & & 2.26 & & & 2.42 & & & 2.21 & & & 3.4 & 1.9 \\
\hline Mar-97 & 2.7 & & & 2.69 & & & 3.16 & & & 2.87 & & & 3.4 & 1.9 \\
\hline Sep-97 & 2.76 & & 2.55 & 2.43 & & & 3.01 & & & 2.38 & & & 3.4 & 1.9 \\
\hline Mar-98 & 2.33 & & & 2.49 & & 2.44 & 2.99 & & & 2.32 & & & 3.4 & 1.9 \\
\hline Aug-98 & 2.59 & & & 2.48 & & & 3.34 & & & 2.34 & & 2.36 & 3.4 & 1.9 \\
\hline Mar-99 & 2.6 & & & 2.8 & & 3 & 3.4 & & & 2.7 & & & 3.4 & 1.9 \\
\hline Sep-99 & 2.65 & & 2.53 & 2.63 & & & 3.41 & & & 2.58 & & & 3.4 & 1.9 \\
\hline Mar-00 & & & & & & & & & & & & & 3.4 & 1.9 \\
\hline Sep-00 & 3.27 & & & 3.19 & & & 3.17 & & 3.62 & & & & 3.4 & 1.9 \\
\hline Mar-01 & 2.31 & & & 2.36 & & & 3.12 & & & 2.83 & & 2.79 & 3.4 & 1.9 \\
\hline Sep-01 & 2.42 & & & 2.25 & & 2.28 & 3.06 & & & 2.65 & & & 3.4 & 1.9 \\
\hline Mar-02 & 2.44 & & 2.52 & 2.46 & & & 3.22 & & & 2.84 & & & 3.4 & 1.9 \\
\hline Sep-02 & 2.25 & & & 2.27 & & 2.14 & 2.99 & & & 2.58 & & & 3.4 & 1.9 \\
\hline Mar-03 & 2.33 & & & 4.22 & & & 3.27 & & & 2.79 & & & 3.4 & 1.9 \\
\hline Sep-03 & 2.19 & & 2.22 & 2.49 & & & 2.97 & & & 2.58 & & & 3.4 & 1.9 \\
\hline Mar-04 & 2.24 & & & 2.12 & & & 2.94 & & & 2.8 & & 3.07 & 3.4 & 1.9 \\
\hline Sep-04 & 2.35 & B & & 2.15 & B & $2.38 \mathrm{~B}$ & 2.95 & B & & 2.59 & B & & 3.4 & 1.9 \\
\hline Mar-05 & 2.26 & & 2.3 & 2.14 & & & 2.86 & & & 2.85 & & & 3.4 & 1.9 \\
\hline Sep-05 & 2 & & & 1.63 & & & 2.34 & & & 2.09 & & 2.2 & 3.4 & 1.9 \\
\hline Mar-06 & 2.35 & & 2.3 & 2.14 & & & 2.94 & & & 2.68 & & & 3.4 & 1.9 \\
\hline Sep-06 & 2.12 & & & 1.94 & & 1.95 & 2.53 & & & 2.72 & & & 3.4 & 1.9 \\
\hline
\end{tabular}

NOTE: Values are in ug/L. 
Table A-7. Tin Data.

\begin{tabular}{|c|c|c|c|c|c|c|c|c|c|c|c|c|c|c|}
\hline $\begin{array}{l}\text { Sample } \\
\text { Date }\end{array}$ & $\begin{array}{c}\text { 699-35-66A } \\
\text { (Down } \\
\text { Gradient) }\end{array}$ & Qual & DUP & $\begin{array}{c}\text { 699-36-67 } \\
\text { (Down } \\
\text { Gradient) }\end{array}$ & Qual & DUP & $\begin{array}{c}\text { 699-36-70A } \\
\text { (Up Gradient) }\end{array}$ & Qual & DUP & $\begin{array}{l}\text { 699-37-68 } \\
\text { (Down } \\
\text { Gradient) }\end{array}$ & Qual & DUP & $\begin{array}{l}\text { Upper } \\
\text { Limit }\end{array}$ & $\begin{array}{l}\text { Lower } \\
\text { Limit }\end{array}$ \\
\hline Mar-96 & 35.3 & $U$ & & 35.3 & U & & 35.3 & U & & 40.1 & B & $35.3 \mathrm{U}$ & 55.6 & -2.1 \\
\hline Sep-96 & 33.5 & $U$ & $0.033 \mathrm{U}$ & 33.5 & U & & 33.5 & $U$ & & 33.5 & $U$ & & 55.6 & -2.1 \\
\hline Mar-97 & 24.7 & $U$ & $24.7 \mathrm{U}$ & 24.7 & U & & 29 & B & & 24.7 & $U$ & & 55.6 & -2.1 \\
\hline Sep-97 & 5.6 & $U$ & $5.6 \mathrm{U}$ & 5.6 & U & & 5.6 & $U$ & & 33.2 & U & & 55.6 & -2.1 \\
\hline Mar-98 & 4.9 & U & & 4.9 & $U$ & $4.9 \mathrm{U}$ & 4.9 & U & & 4.9 & $U$ & & 55.6 & -2.1 \\
\hline Aug-98 & 28 & $U$ & & 28 & U & & 28 & U & & 28 & $U$ & $28 U$ & 55.6 & -2.1 \\
\hline Mar-99 & 2.7 & $U$ & & 2.7 & $U$ & $2.7 \mathrm{U}$ & 2.7 & $U$ & & 2.7 & $U$ & & 55.6 & -2.1 \\
\hline Sep-99 & 2.1 & U & $2.1 \mathrm{U}$ & 2.1 & U & & 2.1 & $U$ & & 2.1 & $U$ & & 55.6 & -2.1 \\
\hline Mar-00 & & & & & & & & & & & & & 55.6 & -2.1 \\
\hline Sep-00 & & & & & & & & & & & & & 55.6 & -2.1 \\
\hline Mar-01 & 3.5 & U & & 3.5 & $U$ & & 3.5 & $U$ & & 3.5 & U & $3.5 \mathrm{U}$ & 55.6 & -2.1 \\
\hline Sep-01 & 2.4 & U & & 100 & U & $100 U$ & 13.9 & $U$ & & 13.9 & U & & 55.6 & -2.1 \\
\hline Mar-02 & 3.3 & U & $3.3 \mathrm{U}$ & 3.3 & $U$ & & 3.3 & $U$ & & 3.3 & U & & 55.6 & -2.1 \\
\hline Sep-02 & 4.7 & U & & 4.7 & U & $4.7 \mathrm{U}$ & 4.7 & $U$ & & 4.7 & U & & 55.6 & -2.1 \\
\hline Mar-03 & 3.6 & U & & 5.8 & U & & 3.6 & $U$ & & 3.6 & U & & 55.6 & -2.1 \\
\hline Sep-03 & 5.6 & $U$ & $5.6 \mathrm{U}$ & 5.6 & U & & 5.6 & $U$ & & 5.6 & U & & 55.6 & -2.1 \\
\hline Mar-04 & 3.6 & U & & 3.6 & U & & 3.6 & U & & 3.6 & U & $3.6 \mathrm{U}$ & 55.6 & -2.1 \\
\hline Sep-04 & 4 & U & & 4 & U & $4 U$ & 4 & $U$ & & 4 & U & & 55.6 & -2.1 \\
\hline Mar-05 & & & & & & & & & & & & & 55.6 & -2.1 \\
\hline Sep-05 & 5.1 & U & & & & & & & & & & & 55.6 & -2.1 \\
\hline Mar-06 & & & & & & & & & & & & & 55.6 & -2.1 \\
\hline Sep-06 & 3.5 & $U$ & & 3.5 & U & 4.6 & 3.5 & $U$ & & 3.5 & $U$ & & 55.6 & -2.1 \\
\hline
\end{tabular}

NOTE: Values are in ug/L. 
Table A-8. Vanadium Data.

\begin{tabular}{|c|c|c|c|c|c|c|c|c|c|c|c|c|c|c|}
\hline $\begin{array}{c}\text { Sample } \\
\text { Date }\end{array}$ & $\begin{array}{c}\text { 699-35-66A } \\
\text { (Down } \\
\text { Gradient) }\end{array}$ & Qual & DUP & $\begin{array}{c}699-36-67 \\
\text { (Down } \\
\text { Gradient) }\end{array}$ & Qual & DUP & $\begin{array}{c}\text { 699-36-70A } \\
\text { (Up } \\
\text { Gradient) }\end{array}$ & Qual & DUP & $\begin{array}{l}699-37-68 \\
\text { (Down } \\
\text { Gradient) }\end{array}$ & Qual & DUP & $\begin{array}{l}\text { Upper } \\
\text { Limit }\end{array}$ & $\begin{array}{l}\text { Lower } \\
\text { Limit }\end{array}$ \\
\hline Mar-96 & 26.8 & J & & 12.6 & $\mathrm{~J}$ & & 23.6 & $\mathrm{~J}$ & & 14.4 & $J$ & $15.1 \mathrm{~J}$ & 41 & 9.9 \\
\hline Sep-96 & 33.4 & B & $0.026 \mathrm{~B}$ & 25.1 & B & & 32.9 & B & & 24.3 & $B$ & & 41 & 9.9 \\
\hline Mar-97 & 33.2 & B & $30.3 \mathrm{~B}$ & 26 & B & & 28.9 & B & & 25.3 & $B$ & & 41 & 9.9 \\
\hline Jun-97 & & & & & & & 36.2 & & & & & & 41 & 9.9 \\
\hline Sep-97 & 27.8 & B & $27.2 B$ & 18.8 & B & & 25.7 & B & 28.8 & 24.9 & B & & 41 & 9.9 \\
\hline Mar-98 & 29 & & & 18.6 & & 18.3 & 26.8 & & 28.4 & 23 & & & 41 & 9.9 \\
\hline Aug-98 & 39.5 & B & & 30.1 & B & & 39.5 & B & & 36 & B & $33.9 \mathrm{~B}$ & 41 & 9.9 \\
\hline Mar-99 & 28.3 & & & 13.9 & & 15 & 25.2 & & 30 & 23.6 & & & 41 & 9.9 \\
\hline Sep-99 & 28.7 & B & $28.6 \mathrm{~B}$ & 17.5 & B & & 26.4 & B & & 23.5 & B & & 41 & 9.9 \\
\hline Jan-00 & & & & & & & 25.7 & B & & & & & 41 & 9.9 \\
\hline Mar-00 & & & & & & & & & & & & & 41 & 9.9 \\
\hline Sep-00 & 27.5 & & & 15.5 & & & 27.2 & & 27.3 & & & & 41 & 9.9 \\
\hline Dec-00 & & & & & & & 27.1 & B & & & & & 41 & 9.9 \\
\hline Mar-01 & 27.1 & & & 16.5 & & & 25.8 & & & 25 & & 25.3 & 41 & 9.9 \\
\hline Sep-01 & 28.5 & & & 50 & U & $50 U$ & 26.2 & & & 22.8 & & & 41 & 9.9 \\
\hline Dec-01 & & & & & & & 26.2 & B & & & & & 41 & 9.9 \\
\hline Mar-02 & 26.6 & & 27.4 & 23.4 & & & 25.6 & & & 23.4 & & & 41 & 9.9 \\
\hline Sep-02 & 28.6 & & & 26.7 & & 1.1 & 28.8 & & & 24.3 & & & 41 & 9.9 \\
\hline Mar-03 & 28.5 & & & 22.1 & & & 26.8 & & & 23.8 & & & 41 & 9.9 \\
\hline Sep-03 & 25.9 & 26.9 & & 24.4 & & & 26.2 & & & 16.2 & & & 41 & 9.9 \\
\hline Mar-04 & 26.8 & & & 24.9 & & & 24.6 & & & 24.2 & & 24.7 & 41 & 9.9 \\
\hline Sep-04 & 27 & C & & 25.4 & C & 25.2 & 26.1 & & & 24.8 & $\mathrm{C}$ & & 41 & 9.9 \\
\hline Mar-05 & 25.8 & & 27.4 & 25.1 & & & 25.9 & & & 23.3 & & & 41 & 9.9 \\
\hline Sep-05 & 25.4 & & & 21.5 & & & 24.9 & & & 27.4 & & 23.4 & 41 & 9.9 \\
\hline Mar-06 & 25.3 & & 27.1 & 24.9 & & & 26.4 & & & 22.9 & & & 41 & 9.9 \\
\hline Sep-06 & 28.8 & C & & 23.7 & C & $23.2 \mathrm{C}$ & 28.6 & C & & 22.7 & C & & 41 & 9.9 \\
\hline
\end{tabular}


Table A-9. Zinc Data.

\begin{tabular}{|c|c|c|c|c|c|c|c|c|c|c|c|c|c|c|}
\hline $\begin{array}{l}\text { Sample } \\
\text { Date }\end{array}$ & $\begin{array}{c}\text { 699-35-66A } \\
\text { (Down } \\
\text { Gradient) }\end{array}$ & Qual & DUP & $\begin{array}{c}\text { 699-36-67 } \\
\text { (Down } \\
\text { Gradient) }\end{array}$ & Qual & DUP & $\begin{array}{c}\text { 699-36-70A } \\
\text { (Up Gradient) }\end{array}$ & $\begin{array}{l}\text { Qu } \\
\text { al }\end{array}$ & DUP & $\begin{array}{c}\text { 699-37-68 } \\
\text { (Down } \\
\text { Gradient) }\end{array}$ & Qual & DUP & $\begin{array}{l}\text { Upper } \\
\text { Limit }\end{array}$ & $\begin{array}{l}\text { Lower } \\
\text { Limit }\end{array}$ \\
\hline Mar-96 & 13.7 & U & & 146 & & & 8.5 & $U$ & & 368 & & 155 & 757 & -354.3 \\
\hline Sep-96 & 15.4 & B & $0.003 \mathrm{U}$ & 260 & & & 23.1 & & & 665 & & & 757 & -354.3 \\
\hline Mar-97 & 26.5 & & 26.7 & 382 & & & 55.4 & & & 507 & & & 757 & -354.3 \\
\hline Jun-97 & & & & & & & 12 & & & & & & 757 & -354.3 \\
\hline Sep-97 & 8.1 & B & 5.7 & 339 & & & 10.3 & & $5.1 \mathrm{U}$ & 394 & & & 757 & -354.3 \\
\hline Mar-98 & 5.8 & B & & 318 & & 321 & 6.1 & B & $2.2 \mathrm{U}$ & 386 & & & 757 & -354.3 \\
\hline Aug-98 & 10.3 & B & & 241 & & & 4.7 & B & & 663 & & 629 & 757 & -354.3 \\
\hline Mar-99 & 2.6 & & & 164 & & 144 & 10.6 & & $0.8 \mathrm{U}$ & 347 & & & 757 & -354.3 \\
\hline Sep-99 & 2.9 & B & $3.5 \mathrm{~B}$ & 215 & & & 0.8 & U & & 350 & & & 757 & -354.3 \\
\hline Jan-00 & & & & & & & 10.4 & B & & & & & 757 & -354.3 \\
\hline Mar-00 & & & & & & & & & & & & & 757 & -354.3 \\
\hline Sep-00 & 7.4 & & & 357 & & & 2.8 & & 4.2 & & & & 757 & -354.3 \\
\hline Dec-00 & & & & & & & 7.1 & $U$ & & & & & 757 & -354.3 \\
\hline Mar-01 & 4.4 & & & 262 & & & 0.94 & & & 17.4 & & 17.5 & 757 & -354.3 \\
\hline Sep-01 & 5.8 & & & 310 & & 325 & 17.1 & & & 24.6 & & & 757 & -354.3 \\
\hline Dec-01 & & & & & & & 1.3 & $U$ & & & & & 757 & -354.3 \\
\hline Mar-02 & 3.1 & & 2.6 & 280 & & & 0.4 & U & & 33.4 & & & 757 & -354.3 \\
\hline Sep-02 & 7.1 & & & 329 & & 0.54 & 2.3 & & & 33.6 & & & 757 & -354.3 \\
\hline Mar-03 & 13.4 & C & & 180 & & & 15 & C & & 34.4 & C & & 757 & -354.3 \\
\hline Sep-03 & 23.7 & C & $2.6 \mathrm{C}$ & 296 & & & 3.1 & & & 8.9 & $\mathrm{C}$ & & 757 & -354.3 \\
\hline Mar-04 & 7.8 & C & & 317 & $C$ & & 5.1 & C & & 12.9 & $\mathrm{C}$ & $9.9 \mathrm{C}$ & 757 & -354.3 \\
\hline Sep-04 & 6.9 & & & 288 & & $286 \mathrm{C}$ & 7.3 & C & & 12.8 & & & 757 & -354.3 \\
\hline Mar-05 & 29.6 & UC & $5.6 \mathrm{UC}$ & 316 & C & & 3.8 & UC & & 15.4 & UC & & 757 & -354.3 \\
\hline Sep-05 & 14.5 & UC & & 266 & $\mathrm{C}$ & & 8.5 & UC & & 9.1 & UC & $8.6 \mathrm{UC}$ & 757 & -354.3 \\
\hline Mar-06 & 9 & UC & $15.9 \cup \mathrm{C}$ & 286 & $\mathrm{C}$ & & 17 & UC & & 12.4 & UC & & 757 & -354.3 \\
\hline Sep-06 & 8.7 & UC & & 259 & C & $260 \mathrm{C}$ & 10.3 & UC & & 6.6 & UC & & 757 & -354.3 \\
\hline
\end{tabular}

NOTE: Values are in ug/L. 
Table A-10. Alkalinity Data. (2 Pages)

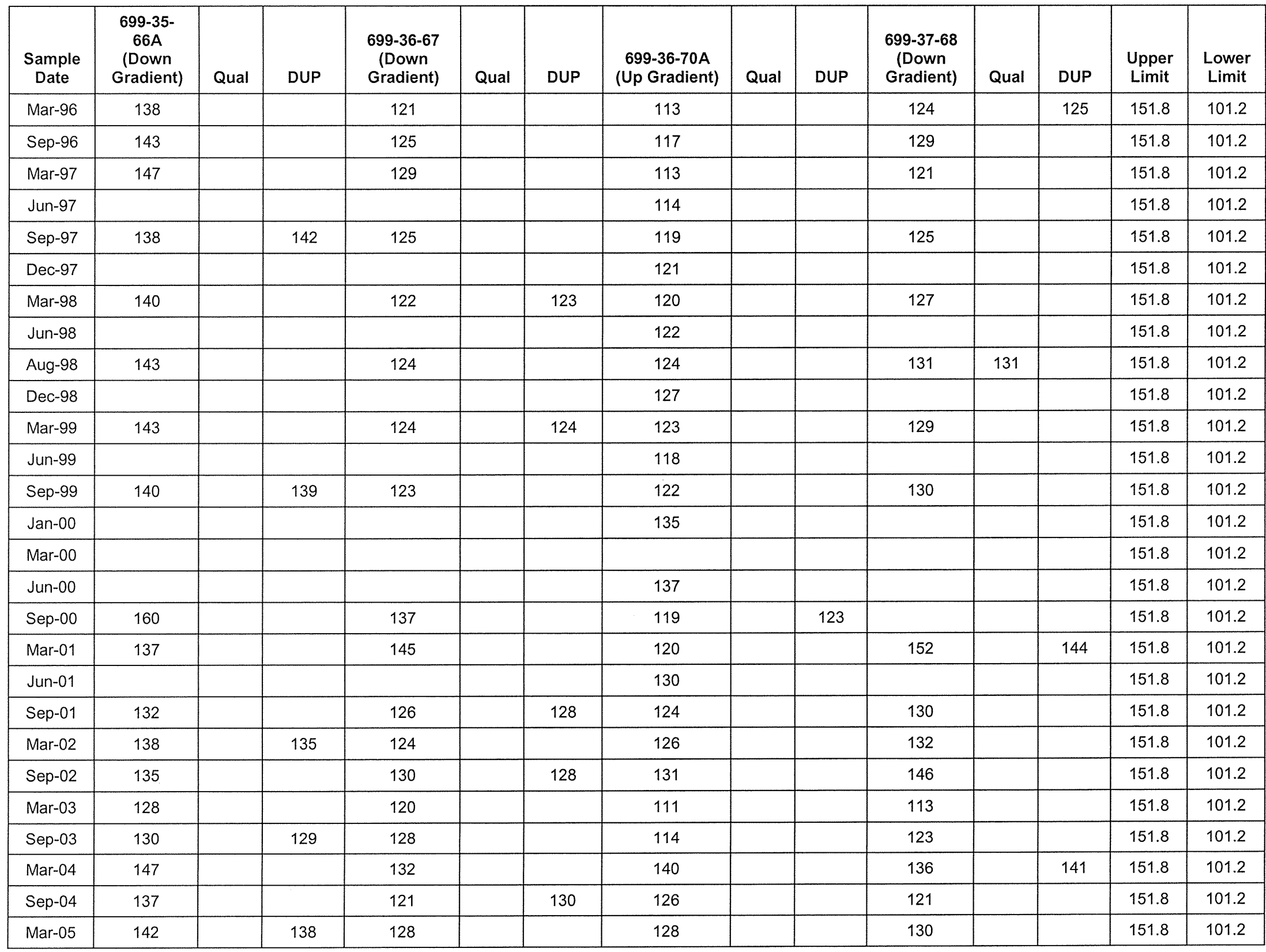


Table A-10. Alkalinity Data. (2 Pages)

\begin{tabular}{|c|c|c|c|c|c|c|c|c|c|c|c|c|c|c|}
\hline $\begin{array}{l}\text { Sample } \\
\text { Date }\end{array}$ & $\begin{array}{c}\text { 699-35- } \\
66 \mathrm{~A} \\
\text { (Down } \\
\text { Gradient) }\end{array}$ & Qual & DUP & $\begin{array}{c}699-36-67 \\
\text { (Down } \\
\text { Gradient) }\end{array}$ & Qual & DUP & $\begin{array}{l}\text { 699-36-70A } \\
\text { (Up Gradient) }\end{array}$ & Qual & DUP & $\begin{array}{l}699-37-68 \\
\text { (Down } \\
\text { Gradient) }\end{array}$ & Qual & DUP & $\begin{array}{l}\text { Upper } \\
\text { Limit }\end{array}$ & $\begin{array}{l}\text { Lower } \\
\text { Limit }\end{array}$ \\
\hline Sep-05 & 138 & & & 132 & & & 126 & & & 126 & & 130 & 151.8 & 101.2 \\
\hline Mar-06 & 139 & & 139 & 128 & & & 124 & & & 128 & & & 151.8 & 101.2 \\
\hline Sep-06 & 137 & & & 125 & & 117 & 120 & & & 123 & & & 151.8 & 101.2 \\
\hline
\end{tabular}

NOTE: Values are in $\mathrm{mg} / \mathrm{L}$. 
Table A-11. Chloride Data. (2 Pages)

\begin{tabular}{|c|c|c|c|c|c|c|c|c|c|c|c|c|c|c|}
\hline $\begin{array}{c}\text { Sample } \\
\text { Date }\end{array}$ & $\begin{array}{l}\text { 699-35-66A } \\
\text { (Down } \\
\text { Gradient) }\end{array}$ & Qual & DUP & $\begin{array}{c}\text { 699-36-67 } \\
\text { (Down } \\
\text { Gradient) }\end{array}$ & Qual & DUP & $\begin{array}{c}699-36-70 \mathrm{~A} \\
\text { (Up Gradient) }\end{array}$ & Qual & DUP & $\begin{array}{c}\text { 699-37-68 } \\
\text { (Down } \\
\text { Gradient) }\end{array}$ & Qual & DUP & $\begin{array}{l}\text { Upper } \\
\text { Limit }\end{array}$ & $\begin{array}{l}\text { Lower } \\
\text { Limit }\end{array}$ \\
\hline Mar-96 & 21.1 & & & 24.2 & & & 24.2 & & & 20.2 & & 20.6 & 25.9 & 17.1 \\
\hline Sep-96 & 19 & & & 22.9 & & & 21.7 & & & 20.1 & & & 25.9 & 17.1 \\
\hline Mar-97 & 19.2 & & & 23.7 & & & & & & 20.08 & & & 25.9 & 17.1 \\
\hline Jun-97 & & & & & & & 22 & D & & & & & 25.9 & 17.1 \\
\hline Sep-97 & 20.5 & & 19.9 & 22.9 & & & 22.4 & & & 21 & & & 25.9 & 17.1 \\
\hline Dec-97 & & & & & & & 20.6 & D & & & & & 25.9 & 17.1 \\
\hline Mar-98 & 16.1 & $C D$ & & 21.4 & D & $21.4 \mathrm{D}$ & 20.9 & $C D$ & & 19.6 & $C D$ & & 25.9 & 17.1 \\
\hline Jun-98 & & & & & & & 21 & & & & & & 25.9 & 17.1 \\
\hline Aug-98 & 18.3 & & & 23.7 & & & 21.4 & & & 20.7 & & 21 & 25.9 & 17.1 \\
\hline Dec-98 & & & & & & & 20.5 & $D$ & & & & & 25.9 & 17.1 \\
\hline Mar-99 & 19.5 & & & 24.9 & & 24.4 & 20.2 & $C D$ & 23.3 & 21.7 & & & 25.9 & 17.1 \\
\hline Jun-99 & & & & & & & 21.2 & $C D$ & & & & & 25.9 & 17.1 \\
\hline Sep-99 & 18.9 & & 19.9 & 26.3 & & & 23.2 & & & 28.1 & & & 25.9 & 17.1 \\
\hline Jan-00 & & & & & & & 20.4 & D & & & & & 25.9 & 17.1 \\
\hline Mar-00 & & & & & & & & & & & & & 25.9 & 17.1 \\
\hline Jun-00 & & & & & & & 20.5 & $\mathrm{DC}$ & & & & & 25.9 & 17.1 \\
\hline Sep-00 & 18.4 & & & 25.7 & & & 21.4 & & 22.4 & & & & 25.9 & 17.1 \\
\hline Dec-00 & & & & & & & 21.9 & D & & & & & 25.9 & 17.1 \\
\hline Mar-01 & 18.6 & & & 25.7 & & & 17.2 & & & 22.3 & & 27.6 & 25.9 & 17.1 \\
\hline Jun-01 & & & & & & & 16.8 & D & & & & & 25.9 & 17.1 \\
\hline Sep-01 & 19 & & & 23.4 & & 24.4 & 20.5 & & & 23.3 & & & 25.9 & 17.1 \\
\hline Dec-01 & & & & & & & 18.6 & D & & & & & 25.9 & 17.1 \\
\hline Mar-02 & 16.6 & & 16.8 & 22.6 & & & 19.3 & & & 25.2 & & & 25.9 & 17.1 \\
\hline Sep-02 & 18 & & & 25.6 & & 24.5 & 20.7 & & & 26.6 & & & 25.9 & 17.1 \\
\hline Mar-03 & 18.3 & & & 22.5 & & & 22.8 & & & 28.2 & & & 25.9 & 17.1 \\
\hline Sep-03 & 15.7 & D & $15.6 \mathrm{D}$ & 22.6 & D & & 23 & D & & 23.8 & D & & 25.9 & 17.1 \\
\hline Mar-04 & 15 & D & & 21.9 & D & & 16.5 & D & & 23.8 & D & 24.3D & 25.9 & 17.1 \\
\hline
\end{tabular}




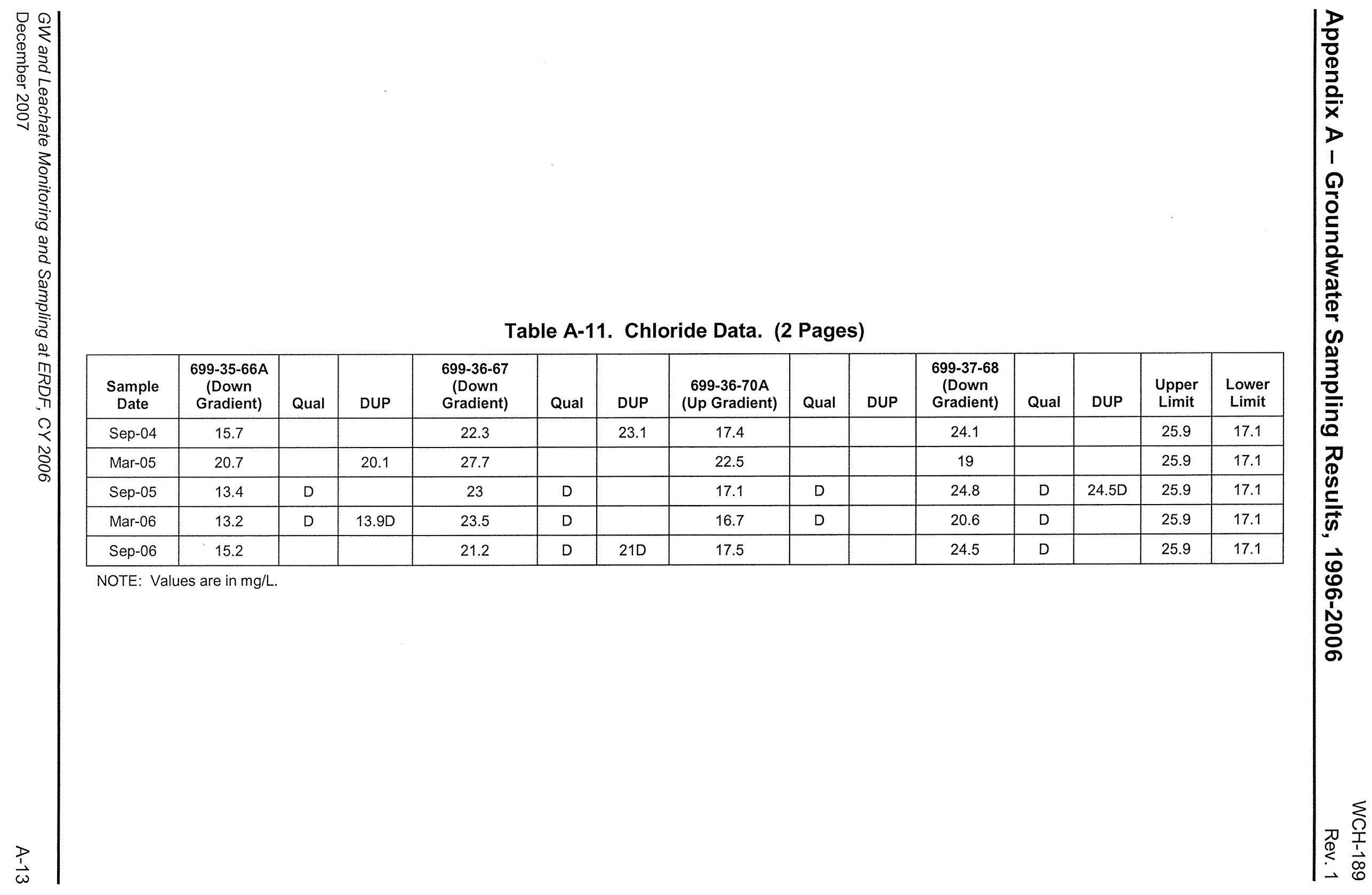


Table A-12. Fluoride Data. (2 Pages)

\begin{tabular}{|c|c|c|c|c|c|c|c|c|c|c|c|c|c|c|}
\hline $\begin{array}{c}\text { Sample } \\
\text { Date }\end{array}$ & $\begin{array}{c}\text { 699-35-66A } \\
\text { (Down } \\
\text { Gradient) }\end{array}$ & Qual & DUP & $\begin{array}{c}699-36-67 \\
\text { (Down } \\
\text { Gradient) }\end{array}$ & Qual & DUP & $\begin{array}{c}\text { 699-36-70A } \\
\text { (Up Gradient) }\end{array}$ & Qual & DUP & $\begin{array}{l}\text { 699-37-68 } \\
\text { (Down } \\
\text { Gradient) }\end{array}$ & Qual & DUP & $\begin{array}{l}\text { Upper } \\
\text { Limit }\end{array}$ & $\begin{array}{l}\text { Lower } \\
\text { Limit }\end{array}$ \\
\hline Mar-96 & 0.34 & & & 0.4 & & & 0.42 & & & 0.36 & & 0.36 & 0.5 & 0.2 \\
\hline Sep-96 & 0.34 & & & 0.37 & & & 0.41 & & & 0.33 & & & 0.5 & 0.2 \\
\hline Mar-97 & 0.34 & & & 0.36 & & & & & & 0.3 & & & 0.5 & 0.2 \\
\hline Jun-97 & & & & & & & 0.406 & & & & & & 0.5 & 0.2 \\
\hline Sep-97 & 0.39 & & 0.334 & 0.348 & & & 0.415 & & & 0.331 & & & 0.5 & 0.2 \\
\hline Dec-97 & & & & & & & 0.378 & & & & & & 0.5 & 0.2 \\
\hline Mar-98 & 0.304 & & & 0.363 & & 0.364 & 0.371 & & & 0.33 & & & 0.5 & 0.2 \\
\hline Jun-98 & & & & & & & 0.383 & & & & & & 0.5 & 0.2 \\
\hline Aug-98 & 0.342 & & & 0.355 & & & 0.362 & & & 0.343 & & 0.34 & 0.5 & 0.2 \\
\hline Dec-98 & & & & & & & 0.399 & & & & & & 0.5 & 0.2 \\
\hline Mar-99 & 0.5 & U & & 0.5 & $U$ & $0.5 \mathrm{U}$ & 0.335 & & $0.5 \mathrm{U}$ & 0.5 & U & & 0.5 & 0.2 \\
\hline Jun-99 & & & & & & & 0.373 & & & & & & 0.5 & 0.2 \\
\hline Sep-99 & 0.5 & $U$ & $0.5 \mathrm{U}$ & 0.5 & U & & 0.5 & U & & 0.5 & U & & 0.5 & 0.2 \\
\hline Jan-00 & & & & & & & 0.41 & & & & & & 0.5 & 0.2 \\
\hline Mar-00 & & & & & & & & & & & & & 0.5 & 0.2 \\
\hline Jun-00 & & & & & & & 0.39 & & & & & & 0.5 & 0.2 \\
\hline Sep-00 & 0.5 & U & & 0.5 & U & & 0.5 & $U$ & $0.5 \mathrm{U}$ & & & & 0.5 & 0.2 \\
\hline Dec-00 & & & & & & & 0.36 & C & & & & & 0.5 & 0.2 \\
\hline Mar-01 & 0.5 & U & & 2.5 & U & & 0.5 & U & & 2.5 & U & $2.5 \mathrm{U}$ & 0.5 & 0.2 \\
\hline Jun-01 & & & & & & & 0.35 & & & & & & 0.5 & 0.2 \\
\hline Sep-01 & 1 & $U$ & & 1 & U & $1 U$ & 0.5 & U & & 0.5 & U & & 0.5 & 0.2 \\
\hline Dec-01 & & & & & & & 0.36 & & & & & & 0.5 & 0.2 \\
\hline Mar-02 & 0.25 & U & $0.25 \mathrm{U}$ & 0.26 & & & 0.28 & & & 0.25 & U & & 0.5 & 0.2 \\
\hline Sep-02 & 0.25 & U & & 0.25 & U & $0.25 \mathrm{U}$ & 0.25 & $U$ & & 0.357 & & & 0.5 & 0.2 \\
\hline Mar-03 & 0.25 & U & & 0.34 & & & 0.3 & & & 0.34 & & & 0.5 & 0.2 \\
\hline Sep-03 & 0.3 & & 0.31 & 0.28 & & & 0.3 & & & 0.25 & U & & 0.5 & 0.2 \\
\hline Mar-04 & 0.3 & & & 0.32 & & & 0.37 & & & 0.286 & & 0.327 & 0.5 & 0.2 \\
\hline Sep-04 & 0.28 & & & 0.34 & & 0.29 & 0.3 & & & 0.26 & & & 0.5 & 0.2 \\
\hline
\end{tabular}




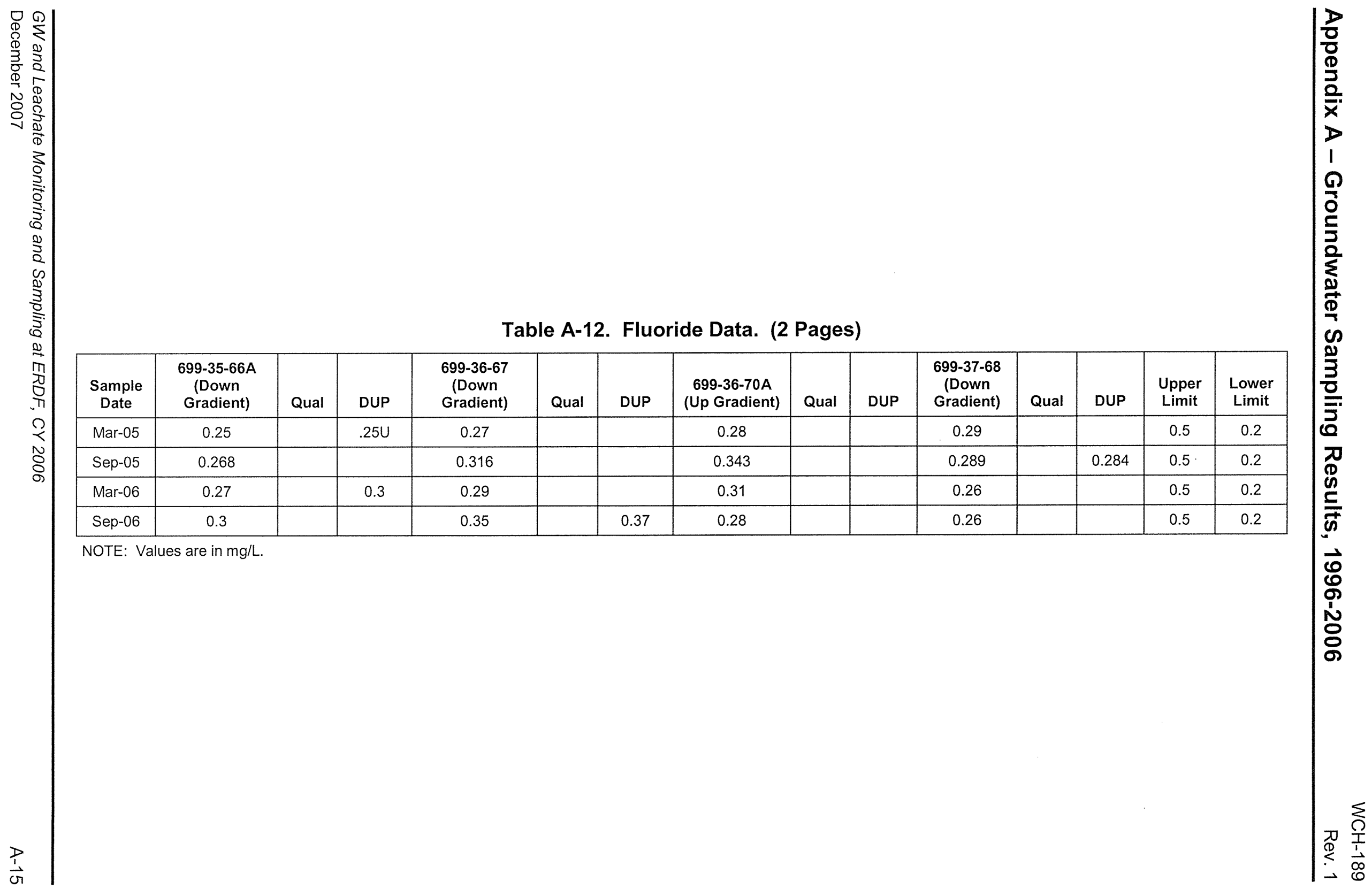


Table A-13. Sulfate Data. (2 Pages)

\begin{tabular}{|c|c|c|c|c|c|c|c|c|c|c|c|c|c|c|}
\hline $\begin{array}{c}\text { Sample } \\
\text { Date }\end{array}$ & $\begin{array}{c}\text { 699-35-66A } \\
\text { (Down } \\
\text { Gradient) }\end{array}$ & Qual & DUP & $\begin{array}{c}\text { 699-36-67 } \\
\text { (Down } \\
\text { Gradient) }\end{array}$ & Qual & DUP & $\begin{array}{c}\text { 699-36-70A (Up } \\
\text { Gradient) }\end{array}$ & Qual & DUP & $\begin{array}{c}699-37-68 \\
\text { (Down } \\
\text { Gradient) }\end{array}$ & Qual & DUP & $\begin{array}{l}\text { Upper } \\
\text { Limit }\end{array}$ & $\begin{array}{l}\text { Lower } \\
\text { Limit }\end{array}$ \\
\hline Mar-96 & 24.2 & & & 29.9 & & & 30.7 & & & 28.9 & & 28.7 & 37.8 & 22.3 \\
\hline Sep-96 & 25.2 & & & 32.2 & & & 33.2 & & & 30.3 & & & 37.8 & 22.3 \\
\hline Mar-97 & 27 & & & 31.5 & & & & & & 30.5 & & & 37.8 & 22.3 \\
\hline Jun-97 & & & & & & & 33.8 & $D$ & & & & & 37.8 & 22.3 \\
\hline Sep-97 & 26.6 & & 26.1 & 32.6 & & & 34.9 & & & 31.4 & & & 37.8 & 22.3 \\
\hline Dec-97 & & & & & & & 34.5 & D & & & & & 37.8 & 22.3 \\
\hline Mar-98 & 22.7 & $D$ & & 31.6 & $D$ & $31.4 \mathrm{D}$ & 34.8 & $D$ & & 31.2 & $D$ & & 37.8 & 22.3 \\
\hline Jun-98 & & & & & & & 35 & & & & & & 37.8 & 22.3 \\
\hline Aug-98 & 26 & & & 30.7 & & & 35.4 & & & 31.8 & & 31.5 & 37.8 & 22.3 \\
\hline Dec-98 & & & & & & & 36.8 & D & & & & & 37.8 & 22.3 \\
\hline Mar-99 & 26.8 & & & 32.4 & & 32 & 37.3 & & $35.2 \mathrm{D}$ & 30.8 & & & 37.8 & 22.3 \\
\hline Jun-99 & & & & & & & 33.2 & D & & & & & 37.8 & 22.3 \\
\hline Sep-99 & 25.9 & & 25.8 & 32.5 & & & 34.6 & & & 31.3 & & & 37.8 & 22.3 \\
\hline Jan-00 & & & & & & & 34.5 & D & & & & & 37.8 & 22.3 \\
\hline Mar-00 & & & & & & & & & & & & & 37.8 & 22.3 \\
\hline Jun-00 & & & & & & & 34.2 & D & & & & & 37.8 & 22.3 \\
\hline Sep-00 & 30.5 & & & 31.7 & & & 37.6 & & 35.9 & & & & 37.8 & 22.3 \\
\hline Dec-00 & & & & & & & 36.8 & D & & & & & 37.8 & 22.3 \\
\hline Mar-01 & 26.9 & & & 36 & & & 31.6 & & & 37.8 & & 39.5 & 37.8 & 22.3 \\
\hline Jun-01 & & & & & & & 36.9 & $D$ & & & & & 37.8 & 22.3 \\
\hline Sep-01 & 27.8 & & & 30.3 & & 30.8 & 34.5 & & & 31 & & & 37.8 & 22.3 \\
\hline Dec-01 & & & & & & & 33.1 & $D$ & & & & & 37.8 & 22.3 \\
\hline Mar-02 & 25.6 & & 25.6 & 29.2 & & & 33.8 & & & 30.5 & & & 37.8 & 22.3 \\
\hline Sep-02 & 26.2 & & & 30.2 & & 29.2 & 32.7 & & & 31.1 & & & 37.8 & 22.3 \\
\hline Mar-03 & 26 & & & 30 & & & 34.7 & & & 31 & & & 37.8 & 22.3 \\
\hline Sep-03 & 26.6 & $\mathrm{D}$ & 26.7D & 31.3 & $D$ & & 34.3 & $D$ & & 31.5 & $D$ & & 37.8 & 22.3 \\
\hline Mar-04 & 26.7 & D & & 31 & D & & 32.2 & $D$ & & 31.5 & $\mathrm{D}$ & $32.4 \mathrm{D}$ & 37.8 & 22.3 \\
\hline Sep-04 & 29.2 & & & 33.7 & & 36 & 37.4 & & & 34.5 & & & 37.8 & 22.3 \\
\hline
\end{tabular}


Table A-13. Sulfate Data. (2 Pages)

\begin{tabular}{|c|c|c|c|c|c|c|c|c|c|c|c|c|c|c|}
\hline $\begin{array}{l}\text { Sample } \\
\text { Date }\end{array}$ & $\begin{array}{l}\text { 699-35-66A } \\
\text { (Down } \\
\text { Gradient) }\end{array}$ & Qual & DUP & $\begin{array}{l}\text { 699-36-67 } \\
\text { (Down } \\
\text { Gradient) }\end{array}$ & Qual & DUP & $\begin{array}{c}\text { 699-36-70A (Up } \\
\text { Gradient) }\end{array}$ & Qual & DUP & $\begin{array}{l}\text { 699-37-68 } \\
\text { (Down } \\
\text { Gradient) }\end{array}$ & Qual & DUP & $\begin{array}{l}\text { Upper } \\
\text { Limit }\end{array}$ & $\begin{array}{l}\text { Lower } \\
\text { Limit }\end{array}$ \\
\hline Mar-05 & 27.7 & & 27.3 & 32.7 & & & 33 & & & 24 & & & 37.8 & 22.3 \\
\hline Sep-05 & 24 & $D$ & & 32.8 & $D$ & & 32.3 & $D$ & & 31.5 & $D$ & $31.1 \mathrm{D}$ & 37.8 & 22.3 \\
\hline Mar-06 & 27.3 & $D$ & $27.4 \mathrm{D}$ & 30.9 & D & & 30.5 & D & & 30.9 & $D$ & & 37.8 & 22.3 \\
\hline Sep-06 & 26.6 & & & 30.2 & $D$ & $29.4 \mathrm{D}$ & 29.9 & & & 29.8 & $D$ & & 37.8 & 22.3 \\
\hline
\end{tabular}

NOTE: Values are in $\mathrm{mg} / \mathrm{L}$. 
Table A-14. Gross Alpha Data. (2 Pages)

\begin{tabular}{|c|c|c|c|c|c|c|c|c|c|c|c|c|c|c|}
\hline $\begin{array}{l}\text { Sample } \\
\text { Date }\end{array}$ & $\begin{array}{c}\text { 699-35-66A } \\
\text { (Down } \\
\text { Gradient) }\end{array}$ & Qual & DUP & $\begin{array}{c}\text { 699-36-67 } \\
\text { (Down } \\
\text { Gradient) }\end{array}$ & Qual & DUP & $\begin{array}{l}\text { 699-36-70A } \\
\text { (Up Gradient) }\end{array}$ & Qual & DUP & $\begin{array}{l}\text { 699-37-68 } \\
\text { (Down } \\
\text { Gradient) }\end{array}$ & Qual & DUP & $\begin{array}{l}\text { Upper } \\
\text { Limit }\end{array}$ & $\begin{array}{l}\text { Lower } \\
\text { Limit }\end{array}$ \\
\hline Mar-96 & 1.45 & $J$ & & 2.12 & J & & 2.28 & $J$ & & 2.43 & J & $1.73 \mathrm{~J}$ & 3.3 & -0.6 \\
\hline Sep-96 & 1.69 & $J$ & & 0.109 & $U$ & & 1.57 & J & & 1.15 & $U$ & & 3.3 & -0.6 \\
\hline Mar-97 & 1.69 & J & $0.199 \mathrm{U}$ & 1.31 & $U$ & & 1.26 & $\mathrm{~J}$ & & 0.837 & $u$ & & 3.3 & -0.6 \\
\hline Jun-97 & & & & & & & 1.68 & J & & & & & 3.3 & -0.6 \\
\hline Sep-97 & 0.39 & U & $1.66 \mathrm{~J}$ & 0.791 & $U$ & & 1.2 & $\mathrm{~J}$ & & 2.5 & $J$ & & 3.3 & -0.6 \\
\hline Dec-97 & & & & & & & 2.36 & $\mathrm{~J}$ & & & & & 3.3 & -0.6 \\
\hline Mar-98 & 1.32 & $\mathrm{~J}$ & & 0.659 & U & $1.4 \mathrm{~J}$ & 2.17 & $\mathrm{~J}$ & & 0.683 & $U$ & & 3.3 & -0.6 \\
\hline Jun-98 & & & & & & & 2.17 & $U$ & & & & & 3.3 & -0.6 \\
\hline Aug-98 & 0.431 & U & & 2.3 & J & & 2.89 & $\mathrm{~J}$ & & 2.45 & $\mathrm{~J}$ & 3.37 & 3.3 & -0.6 \\
\hline Dec-98 & & & & & & & 1.87 & $\mathrm{~J}$ & & & & & 3.3 & -0.6 \\
\hline Mar-99 & 2.7 & $J$ & & 3 & & $1.3 \mathrm{U}$ & 1.68 & U & $1.3 \mathrm{U}$ & 1.5 & $U$ & & 3.3 & -0.6 \\
\hline Jun-99 & & & & & & & 2.75 & $\mathrm{~J}$ & & & & & 3.3 & -0.6 \\
\hline Sep-99 & 2.64 & $J$ & $0.565 \mathrm{U}$ & 0.535 & U & & 1.31 & $U$ & $0.928 \mathrm{U}$ & 1.55 & U & & 3.3 & -0.6 \\
\hline Jan-00 & & & & & & & 3.75 & & & & & & 3.3 & -0.6 \\
\hline Mar-00 & & & & & & & & & & & & & 3.3 & -0.6 \\
\hline Jun-00 & & & & & & & 3.29 & & & & & & 3.3 & -0.6 \\
\hline Sep-00 & 0.34 & U & & 0.5 & U & & 0.266 & U & $1.28 \mathrm{U}$ & & & & 3.3 & -0.6 \\
\hline Dec-00 & & & & & & & 2.06 & U & & & & & 3.3 & -0.6 \\
\hline Mar-01 & 0.303 & U & & 1.01 & U & & 2.33 & $\mathrm{~J}$ & & 0.812 & U & $1.43 \mathrm{U}$ & 3.3 & -0.6 \\
\hline Sep-01 & -0.386 & U & & 0.976 & U & $0.751 \cup$ & 1.12 & U & & 0.374 & U & & 3.3 & -0.6 \\
\hline Mar-02 & 0.884 & U & $0.227 \mathrm{U}$ & 0.522 & U & & 0.363 & U & & 0.016 & U & & 3.3 & -0.6 \\
\hline Sep-02 & 0.348 & U & & 0.38 & U & $0.91 U$ & 0.289 & U & & -0.377 & U & & 3.3 & -0.6 \\
\hline Mar-03 & 0.748 & U & & 6.01 & & & 0.865 & U & & 1.68 & & & 3.3 & -0.6 \\
\hline Sep-03 & 1.44 & & $0.882 U$ & 1.11 & U & & 1.16 & U & & 1.64 & & & 3.3 & -0.6 \\
\hline Mar-04 & 2.26 & & & 1.73 & $U$ & & 1.83 & $U$ & & 1.52 & & 2.13 & 3.3 & -0.6 \\
\hline Sep-04 & 1.21 & & & -0.435 & U & $-0.17 \mathrm{U}$ & 0.487 & U & & 0.531 & U & & 3.3 & -0.6 \\
\hline Mar-05 & 1.53 & & $0.817 \mathrm{U}$ & 1.33 & & & 0.913 & $U$ & & 1.68 & & & 3.3 & -0.6 \\
\hline Sep-05 & 0.862 & $U$ & & 1.06 & $U$ & & 0.646 & $U$ & & 1.16 & U & 1.78 & 3.3 & -0.6 \\
\hline
\end{tabular}




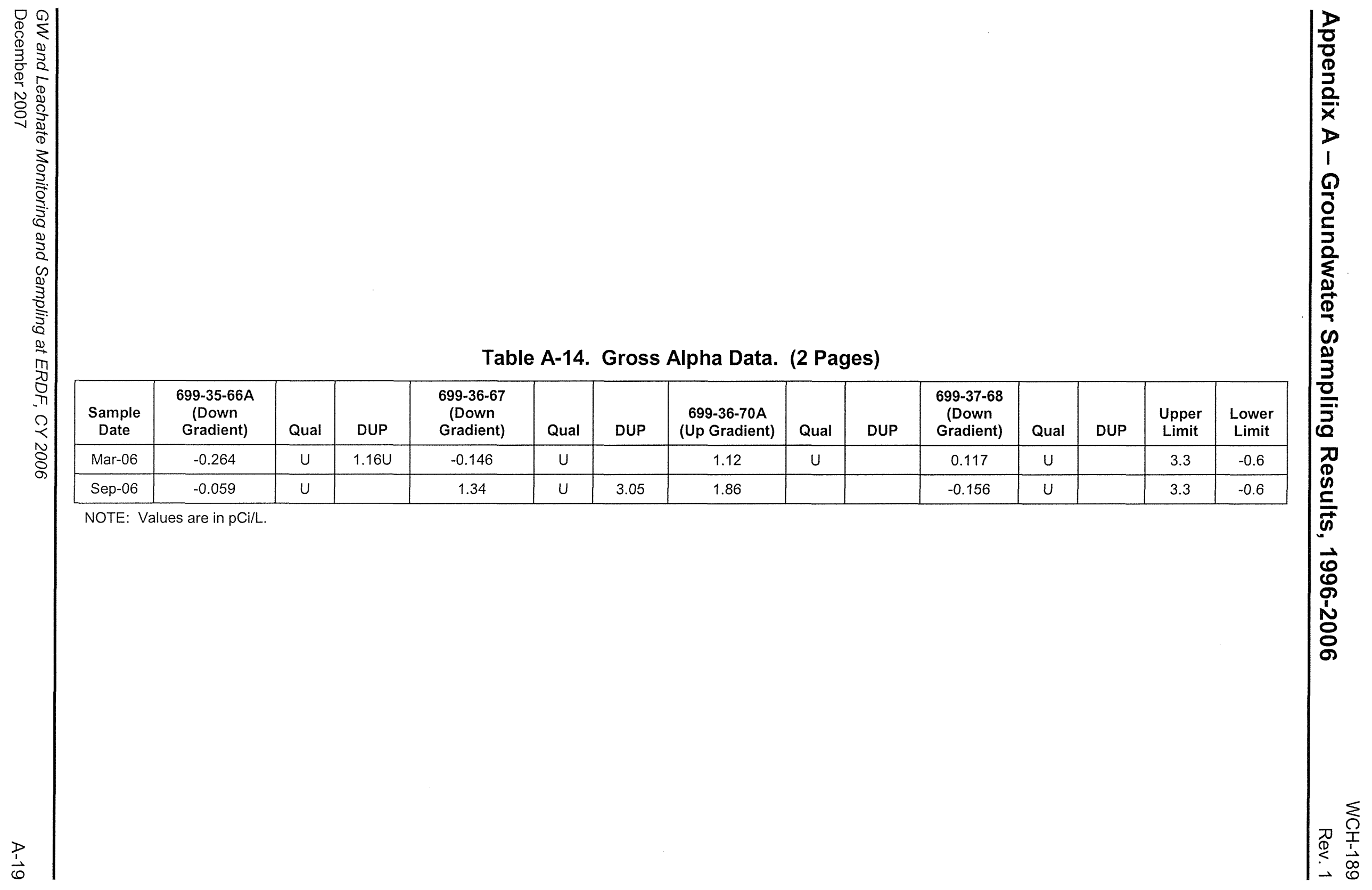


Table A-15. Gross Beta Data. (2 Pages)

\begin{tabular}{|c|c|c|c|c|c|c|c|c|c|c|c|c|c|c|}
\hline $\begin{array}{l}\text { Sample } \\
\text { Date }\end{array}$ & $\begin{array}{l}\text { 699-35-66A } \\
\text { (Down } \\
\text { Gradient) }\end{array}$ & Qual & DUP & $\begin{array}{c}\text { 699-36-67 } \\
\text { (Down } \\
\text { Gradient) }\end{array}$ & Qual & DUP & $\begin{array}{c}\text { 699-36-70A } \\
\text { (Up Gradient) }\end{array}$ & Qual & DUP & $\begin{array}{l}\text { 699-37-68 } \\
\text { (Down } \\
\text { Gradient) }\end{array}$ & Qual & DUP & $\begin{array}{l}\text { Upper } \\
\text { Limit }\end{array}$ & $\begin{array}{l}\text { Lower } \\
\text { Limit }\end{array}$ \\
\hline Mar-96 & 10.9 & & & 22.4 & & & 20.4 & & & 16 & & 15.5 & 31.7 & 4.8 \\
\hline Sep-96 & 13.2 & & & 26.9 & & & 25.7 & & & 17.6 & & & 31.7 & 4.8 \\
\hline Mar-97 & 11.2 & & 10.5 & 21.6 & & & 23.2 & & & 13.5 & & & 31.7 & 4.8 \\
\hline Jun-97 & & & & & & & 16.3 & & & & & & 31.7 & 4.8 \\
\hline Sep-97 & 10.2 & & 12.7 & 20.7 & & & 21 & & & 15.9 & & & 31.7 & 4.8 \\
\hline Dec-97 & & & & & & & 21.4 & & & & & & 31.7 & 4.8 \\
\hline Mar-98 & 10.5 & & & 26.4 & & 25.4 & 20.2 & & & 14.5 & & & 31.7 & 4.8 \\
\hline Jun-98 & & & & & & & 44.7 & & & & & & 31.7 & 4.8 \\
\hline Aug-98 & 17.1 & & & 27.4 & & & 25.1 & & & 19.1 & & 13.4 & 31.7 & 4.8 \\
\hline Dec-98 & & & & & & & 21.3 & & & & & & 31.7 & 4.8 \\
\hline Mar-99 & 25 & & & 17 & & 67 & 25.1 & & 56 & 27 & & & 31.7 & 4.8 \\
\hline Jun-99 & & & & & & & 25.8 & & & & & & 31.7 & 4.8 \\
\hline Sep-99 & 25.1 & & 25.8 & 57.2 & & & 38 & & 50.2 & 27.1 & & & 31.7 & 4.8 \\
\hline Jan-00 & & & & & & & 21.7 & & & & & & 31.7 & 4.8 \\
\hline Mar-00 & & & & & & & & & & & & & 31.7 & 4.8 \\
\hline Jun-00 & & & & & & & 21.6 & & & & & & 31.7 & 4.8 \\
\hline Sep-00 & 27.6 & & & 49.2 & & & 49.9 & & 47.4 & & & & 31.7 & 4.8 \\
\hline Dec-00 & & & & & & & 23.4 & & & & & & 31.7 & 4.8 \\
\hline Mar-01 & 26.2 & & & 59.4 & & & 47.8 & & & 31.9 & & 35.5 & 31.7 & 4.8 \\
\hline Sep-01 & 29.8 & & & 41.2 & & 39.6 & 41.2 & & & 29.8 & & & 31.7 & 4.8 \\
\hline Mar-02 & 28 & & 28.5 & 39.1 & & & 42.7 & & & 30.8 & & & 31.7 & 4.8 \\
\hline Sep-02 & 23.3 & & & 28.3 & & 26.3 & 28.7 & & & 21.4 & & & 31.7 & 4.8 \\
\hline Mar-03 & 38.8 & & & 47 & & & 44.3 & & & 36.8 & & & 31.7 & 4.8 \\
\hline Sep-03 & 38.1 & & 38.1 & 35.6 & & & 44 & & & 41.5 & & & 31.7 & 4.8 \\
\hline Mar-04 & 25.8 & & & 28.1 & & & 29.8 & & & 36.2 & & 41.3 & 31.7 & 4.8 \\
\hline Sep-04 & 39.1 & & & 34.1 & & 34.3 & 33.8 & & & 38.3 & & & 31.7 & 4.8 \\
\hline Mar-05 & 41.4 & & 38.4 & 32.9 & & & 33.2 & & & 36.9 & & & 31.7 & 4.8 \\
\hline Sep-05 & 44.6 & & & 35.8 & & & 27.8 & & & 41.6 & & 41.2 & 31.7 & 4.8 \\
\hline
\end{tabular}




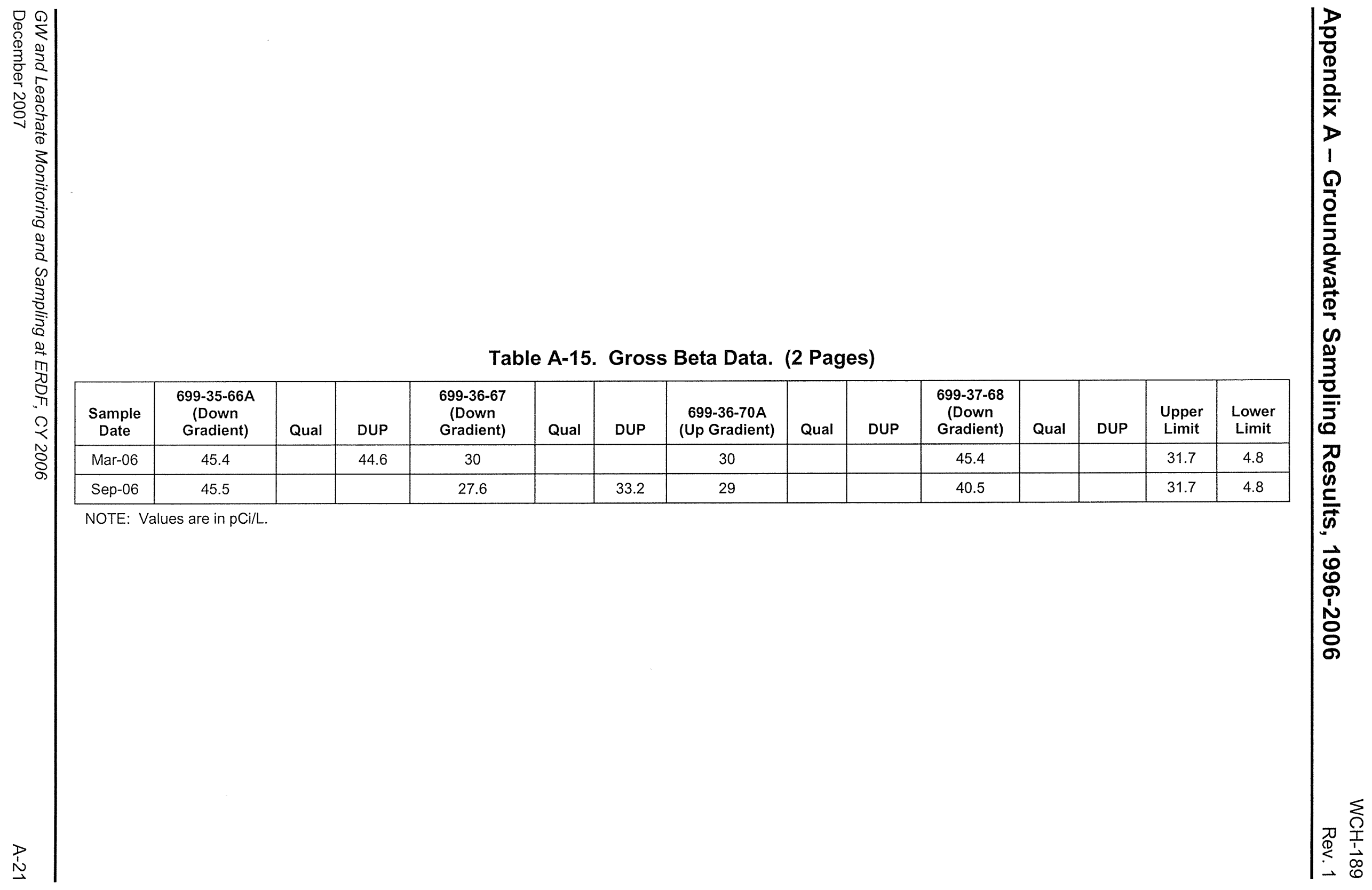


Table A-16. Carbon-14 Data.

\begin{tabular}{|c|c|c|c|c|c|c|c|c|c|c|c|c|c|c|}
\hline $\begin{array}{l}\text { Sample } \\
\text { Date }\end{array}$ & $\begin{array}{l}\text { 699-35-66A } \\
\text { (Down } \\
\text { Gradient) }\end{array}$ & Qual & DUP & $\begin{array}{l}\text { 699-36-67 } \\
\text { (Down } \\
\text { Gradient) }\end{array}$ & Qual & DUP & $\begin{array}{c}\text { 699-36-70A (Up } \\
\text { Gradient) }\end{array}$ & Qual & DUP & $\begin{array}{l}\text { 699-37-68 } \\
\text { (Down } \\
\text { Gradient) }\end{array}$ & Qual & DUP & $\begin{array}{l}\text { Upper } \\
\text { Limit }\end{array}$ & $\begin{array}{l}\text { Lower } \\
\text { Limit }\end{array}$ \\
\hline Mar-96 & 22.3 & J & & 6.76 & J & & 4.26 & $\mathrm{~J}$ & & 4.72 & $\mathrm{~J}$ & $2.48 \mathrm{U}$ & 26.8 & -10.5 \\
\hline Sep-96 & & & & & & & & & & & & & 26.8 & -10.5 \\
\hline Mar-97 & 21.6 & $\mathrm{~J}$ & $22.2 \mathrm{~J}$ & 11.1 & $\mathrm{~J}$ & & 3.94 & U & & 3.81 & $u$ & & 26.8 & -10.5 \\
\hline Sep-97 & 16.7 & $\mathrm{~J}$ & $10.7 \mathrm{~J}$ & 3.27 & $u$ & & 1.6 & $U$ & & 5.43 & U & & 26.8 & -10.5 \\
\hline Mar-98 & 19.4 & $\mathrm{~J}$ & & 4.5 & U & $7.16 \mathrm{U}$ & 3.69 & U & & -1.49 & U & & 26.8 & -10.5 \\
\hline Aug-98 & 18.5 & $\mathrm{~J}$ & & 8.63 & $\mathrm{~J}$ & & 2.07 & U & & 6.46 & U & $6.4 \mathrm{U}$ & 26.8 & -10.5 \\
\hline Mar-99 & 25 & $U$ & & 9.9 & $U$ & $12 U$ & -6.1 & $U$ & & -6.5 & U & & 26.8 & -10.5 \\
\hline Sep-99 & 14.1 & u & $7.43 \mathrm{U}$ & -2.74 & U & & -9.54 & $U$ & & -5.94 & U & & 26.8 & -10.5 \\
\hline Mar-00 & & & & & & & & & & & & & 26.8 & -10.5 \\
\hline Sep-00 & 35.2 & U & & 13.7 & $U$ & & 3.75 & U & $4.81 U$ & & & & 26.8 & -10.5 \\
\hline Mar-01 & 9.56 & u & & 43.4 & u & & -28.1 & U & & 47.2 & u & $57 \mathrm{~J}$ & 26.8 & -10.5 \\
\hline Sep-01 & 32.5 & $u$ & & 6.73 & U & $22.5 \mathrm{U}$ & -15.1 & $u$ & & -1.16 & $u$ & & 26.8 & -10.5 \\
\hline Mar-02 & 14 & $u$ & $21.4 \mathrm{U}$ & 11.6 & U & & 21.7 & $u$ & & 13.2 & $u$ & & 26.8 & -10.5 \\
\hline Sep-02 & 5.02 & U & & 17 & $u$ & $32.6 \mathrm{U}$ & -1.55 & $u$ & & 8.45 & U & & 26.8 & -10.5 \\
\hline Mar-03 & -6.69 & $u$ & & -0.225 & $U$ & & 25.2 & $u$ & & 1.78 & $u$ & & 26.8 & -10.5 \\
\hline Sep-03 & 0.446 & $u$ & $3.32 \mathrm{U}$ & 5.74 & $u$ & & $\begin{array}{l}-10.3 \\
\end{array}$ & $u$ & & -4.5 & U & & 26.8 & -10.5 \\
\hline Mar-04 & 33.9 & $u$ & & 16.4 & U & & 10.2 & $u$ & & 9.75 & U & $-12.4 \mathrm{U}$ & 26.8 & -10.5 \\
\hline Sep-04 & 8.8 & u & & 0 & u & $6.99 \mathrm{U}$ & 1.22 & $u$ & & 2.45 & $u$ & & 26.8 & -10.5 \\
\hline Mar-05 & 11.8 & $u$ & $42.2 \mathrm{U}$ & 38.6 & $u$ & & 17.8 & $u$ & & 28.9 & $u$ & & 26.8 & -10.5 \\
\hline Sep-05 & 19.9 & u & & 8.17 & U & & -2.4 & $u$ & & -2.37 & $U$ & $-10.7 U$ & 26.8 & -10.5 \\
\hline Mar-06 & 34.2 & $u$ & $16.1 U$ & 1.44 & $U$ & & -22.6 & $u$ & & 6.04 & $u$ & & 26.8 & -10.5 \\
\hline Sep-06 & 15.8 & U & & 1.42 & $u$ & $-5.16 U$ & 13.6 & $u$ & & -4.74 & U & & 26.8 & -10.5 \\
\hline
\end{tabular}

NOTE: Values are in $p C i / L$. 
Table A-17. lodine-129 Data. (2 Pages)

\begin{tabular}{|c|c|c|c|c|c|c|c|c|c|c|c|c|c|c|}
\hline $\begin{array}{l}\text { Sample } \\
\text { Date }\end{array}$ & $\begin{array}{c}\text { 699-35-66A } \\
\text { (Down } \\
\text { Gradient) }\end{array}$ & Qual & DUP & $\begin{array}{c}\text { 699-36-67 } \\
\text { (Down } \\
\text { Gradient) }\end{array}$ & Qual & DUP & $\begin{array}{c}\text { 699-36-70A (Up } \\
\text { Gradient) }\end{array}$ & Qual & DUP & $\begin{array}{l}\text { 699-37-68 } \\
\text { (Down } \\
\text { Gradient) }\end{array}$ & Qual & DUP & $\begin{array}{l}\text { Upper } \\
\text { Limit }\end{array}$ & $\begin{array}{l}\text { Lower } \\
\text { Limit }\end{array}$ \\
\hline Jan-95 & & & & & & & 38.8 & $J$ & & & & & 21.5 & -2.4 \\
\hline Jun-95 & & & & & & & 19.9 & & & & & & 21.5 & -2.4 \\
\hline Jan-96 & & & & 3.06 & $U$ & & & & & 1.04 & $U$ & & 21.5 & -2.4 \\
\hline Mar-96 & 9.4 & & & 9.42 & & & 18.7 & & & 6.01 & & $3.69 \mathrm{U}$ & 21.5 & -2.4 \\
\hline Sep-96 & 7.54 & & & 11.9 & & & 13.7 & & & 2.22 & $U$ & & 21.5 & -2.4 \\
\hline Mar-97 & 10.1 & & 11 & 7.81 & & & 11.8 & & & 2.82 & $J$ & & 21.5 & -2.4 \\
\hline Jun-97 & & & & & & & 12.3 & & & & & & 21.5 & -2.4 \\
\hline Sep-97 & 9.52 & & 11.3 & 9.73 & & & 16.2 & & & 3.03 & J & & 21.5 & -2.4 \\
\hline Mar-98 & 8.07 & & $4.54 \mathrm{U}$ & 13.2 & & $9.83 \mathrm{U}$ & 15.2 & & 15.2 & 1.62 & U & $1.62 \mathrm{U}$ & 21.5 & -2.4 \\
\hline Aug-98 & 9.6 & & & 12.2 & & & 15.2 & & & 2.57 & & 2.78 & 21.5 & -2.4 \\
\hline Mar-99 & 6.1 & & & 7.9 & & $1.2 \mathrm{U}$ & 14.4 & & $3.8 \mathrm{U}$ & 2.9 & U & & 21.5 & -2.4 \\
\hline Sep-99 & 5.68 & & 6.96 & 9.24 & & & 6.54 & $U$ & & 1.87 & U & & 21.5 & -2.4 \\
\hline Jan-00 & & & & & & & 12.9 & & & & & & 21.5 & -2.4 \\
\hline Mar-00 & & & & & & & & & & & & & 21.5 & -2.4 \\
\hline Sep-00 & 0.307 & $U$ & & 11 & & & 13.9 & & 13.1 & & & & 21.5 & -2.4 \\
\hline Dec-00 & & & & & & & 13.3 & & & & & & 21.5 & -2.4 \\
\hline Mar-01 & 4.63 & U & & 13.8 & & & 16.7 & & & 6.72 & & $2.74 \mathrm{U}$ & 21.5 & -2.4 \\
\hline Jun-01 & & & & & & & 7.37 & & & & & & 21.5 & -2.4 \\
\hline Sep-01 & 3.1 & $U$ & & 12.3 & & $-5.52 \mathrm{U}$ & 13.8 & & & 4.59 & J & & 21.5 & -2.4 \\
\hline Dec-01 & & & & & & & 9.14 & & & & & & 21.5 & -2.4 \\
\hline Mar-02 & 4.09 & & 3.79 & 9.71 & & 10.7 & 13.9 & & & 2.2 & & $2.16 \mathrm{U}$ & 21.5 & -2.4 \\
\hline Sep-02 & 4.66 & J & & 8.34 & & 12 & 14.3 & & & 2.3 & U & & 21.5 & -2.4 \\
\hline Mar-03 & 4.97 & & & 12.1 & & & 14.2 & & & 3.43 & & & 21.5 & -2.4 \\
\hline Sep-03 & 2.91 & U & $-9.28 U$ & 7.88 & U & & 13.4 & & & -1.82 & U & & 21.5 & -2.4 \\
\hline Mar-04 & 4.86 & & & 11.8 & & & 11 & & & 2.44 & U & $1.64 \mathrm{U}$ & 21.5 & -2.4 \\
\hline Sep-04 & 4.99 & & & 13.6 & & 13.3 & 6.53 & & & 2.52 & $U$ & & 21.5 & -2.4 \\
\hline Mar-05 & 5.25 & U & $3.66 \mathrm{U}$ & 15.5 & & & 10.6 & & & -1.61 & U & & 21.5 & -2.4 \\
\hline Sep-05 & 5.30 & & & 14.6 & & & 12.5 & & & 2.42 & $U$ & $2.45 \mathrm{U}$ & 21.5 & -2.4 \\
\hline
\end{tabular}




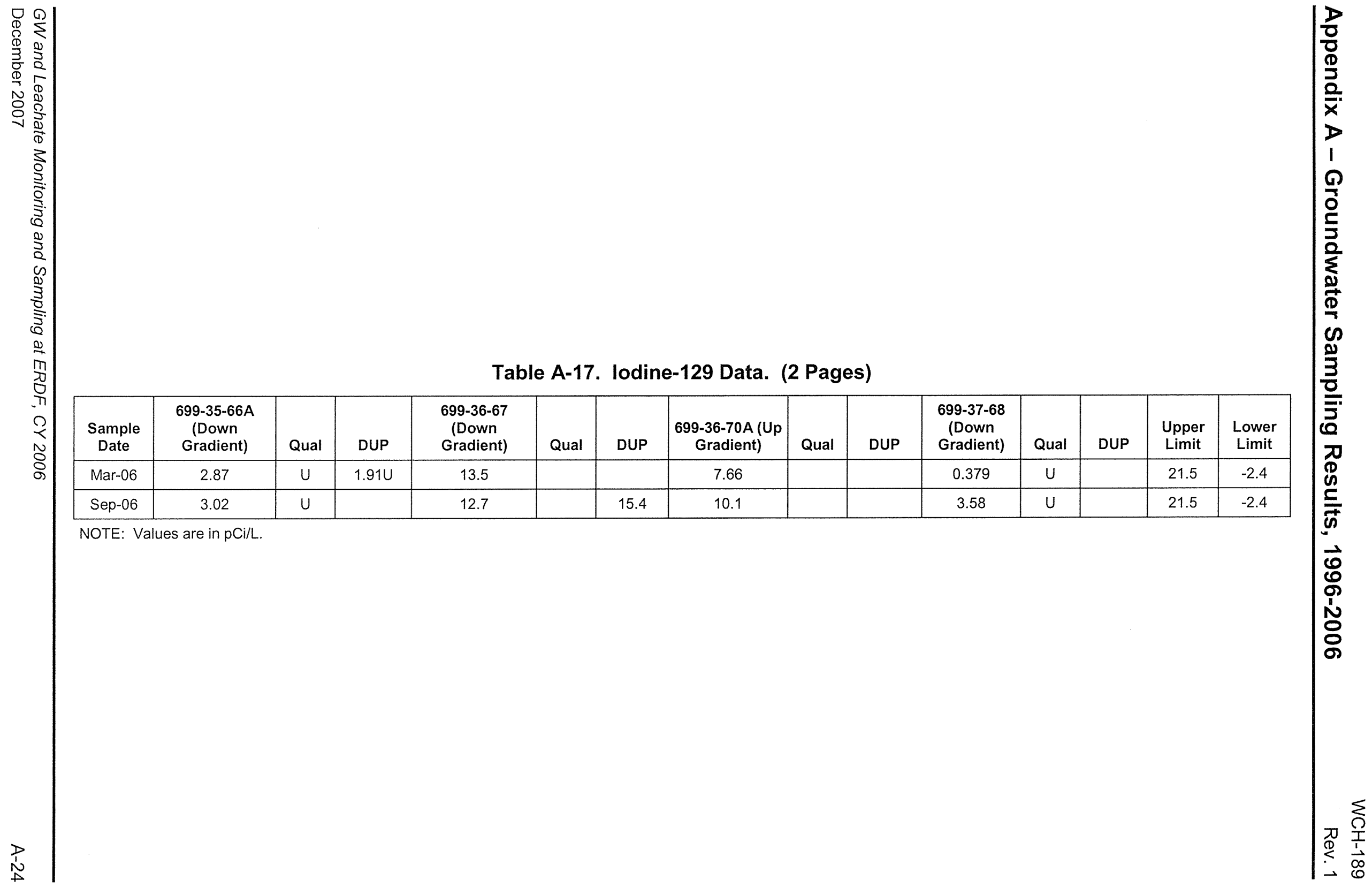


Table A-18. Technetium-99 Data. (2 Pages)

\begin{tabular}{|c|c|c|c|c|c|c|c|c|c|c|c|c|c|c|}
\hline $\begin{array}{l}\text { Sample } \\
\text { Date }\end{array}$ & $\begin{array}{c}\text { 699-35-66A } \\
\text { (Down } \\
\text { Gradient) }\end{array}$ & Qual & DUP & $\begin{array}{l}\text { 699-36-67 } \\
\text { (Down } \\
\text { Gradient) }\end{array}$ & Qual & DUP & $\begin{array}{c}\text { 699-36-70A (Up } \\
\text { Gradient) }\end{array}$ & Qual & DUP & $\begin{array}{l}\text { 699-37-68 } \\
\text { (Down } \\
\text { Gradient) }\end{array}$ & Qual & DUP & $\begin{array}{l}\text { Upper } \\
\text { Limit }\end{array}$ & $\begin{array}{l}\text { Lower } \\
\text { Limit }\end{array}$ \\
\hline Sep-95 & & & & & & & 60.2 & & & & & & 94.9 & -6.3 \\
\hline Mar-96 & 25.5 & & & 65 & & & 64.2 & & & 31 & & 32 & 94.9 & -6.3 \\
\hline Sep-96 & 20.3 & & & 53.5 & & & 52.3 & & & 32.1 & & & 94.9 & -6.3 \\
\hline Mar-97 & 20 & 21.6 & & 77.5 & & & 59.9 & & & 30 & & & 94.9 & -6.3 \\
\hline Jun-97 & & & & & & & 64 & & & & & & 94.9 & -6.3 \\
\hline Sep-97 & 18.9 & & 17.3 & 66.8 & & & 57 & & & 34.8 & & & 94.9 & -6.3 \\
\hline Dec-97 & & & & & & & 64.2 & & & & & & 94.9 & -6.3 \\
\hline Mar-98 & 23.2 & & & 68.6 & & 75.4 & 78.2 & & & 23.5 & & & 94.9 & -6.3 \\
\hline Jun-98 & & & & & & & 73.6 & & & & & & 94.9 & -6.3 \\
\hline Aug-98 & 29.4 & & & 74.9 & & & 77.4 & & & 36.5 & & 16.5 & 94.9 & -6.3 \\
\hline Dec-98 & & & & & & & 72 & & & & & & 94.9 & -6.3 \\
\hline Mar-99 & 0 & U & & 86 & & 83 & 70.5 & U & OU & 36 & & & 94.9 & -6.3 \\
\hline Jun-99 & & & & & & & 0.0737 & $\mathrm{~J}$ & & & & & 94.9 & -6.3 \\
\hline Sep-99 & 40.4 & & 34.3 & 85.2 & & & 90.1 & & & 44.6 & & & 94.9 & -6.3 \\
\hline Jan-00 & & & & & & & 126 & & & & & & 94.9 & -6.3 \\
\hline Mar-01 & & & & & & & & & & & & & 94.9 & -6.3 \\
\hline Jun-00 & & & & & & & 85.7 & & & & & & 94.9 & -6.3 \\
\hline Sep-00 & 35.6 & & & 80.1 & & & 85.6 & & 76.5 & & & & 94.9 & -6.3 \\
\hline Dec-00 & & & & & & & 60.9 & & & & & & 94.9 & -6.3 \\
\hline Mar-01 & 45.5 & & & 75.9 & & & 92 & & & 40.2 & & 42.3 & 94.9 & -6.3 \\
\hline Jun-01 & & & & & & & 61.3 & & & & & & 94.9 & -6.3 \\
\hline Sep-01 & 47.6 & & & 56.5 & & 63.7 & 72.3 & & & 46.9 & & & 94.9 & -6.3 \\
\hline Dec-01 & & & & & & & 66.3 & & & & & & 94.9 & -6.3 \\
\hline Mar-02 & 51.4 & & 61.3 & 71.8 & & & 76.1 & & & 46.3 & & & 94.9 & -6.3 \\
\hline Sep-02 & 52.8 & & & 59.7 & & 51.6 & 67.1 & & & 58.8 & & & 94.9 & -6.3 \\
\hline Mar-03 & 61.3 & & & 62.1 & & & 66.3 & & & 56.5 & & & 94.9 & -6.3 \\
\hline Sep-03 & 57.7 & & 59.5 & 54.5 & & & 58.3 & & & 58.7 & & & 94.9 & -6.3 \\
\hline Mar-04 & 59.4 & & & 54.7 & & & 56.4 & & & 66.7 & & 68.1 & 94.9 & -6.3 \\
\hline
\end{tabular}




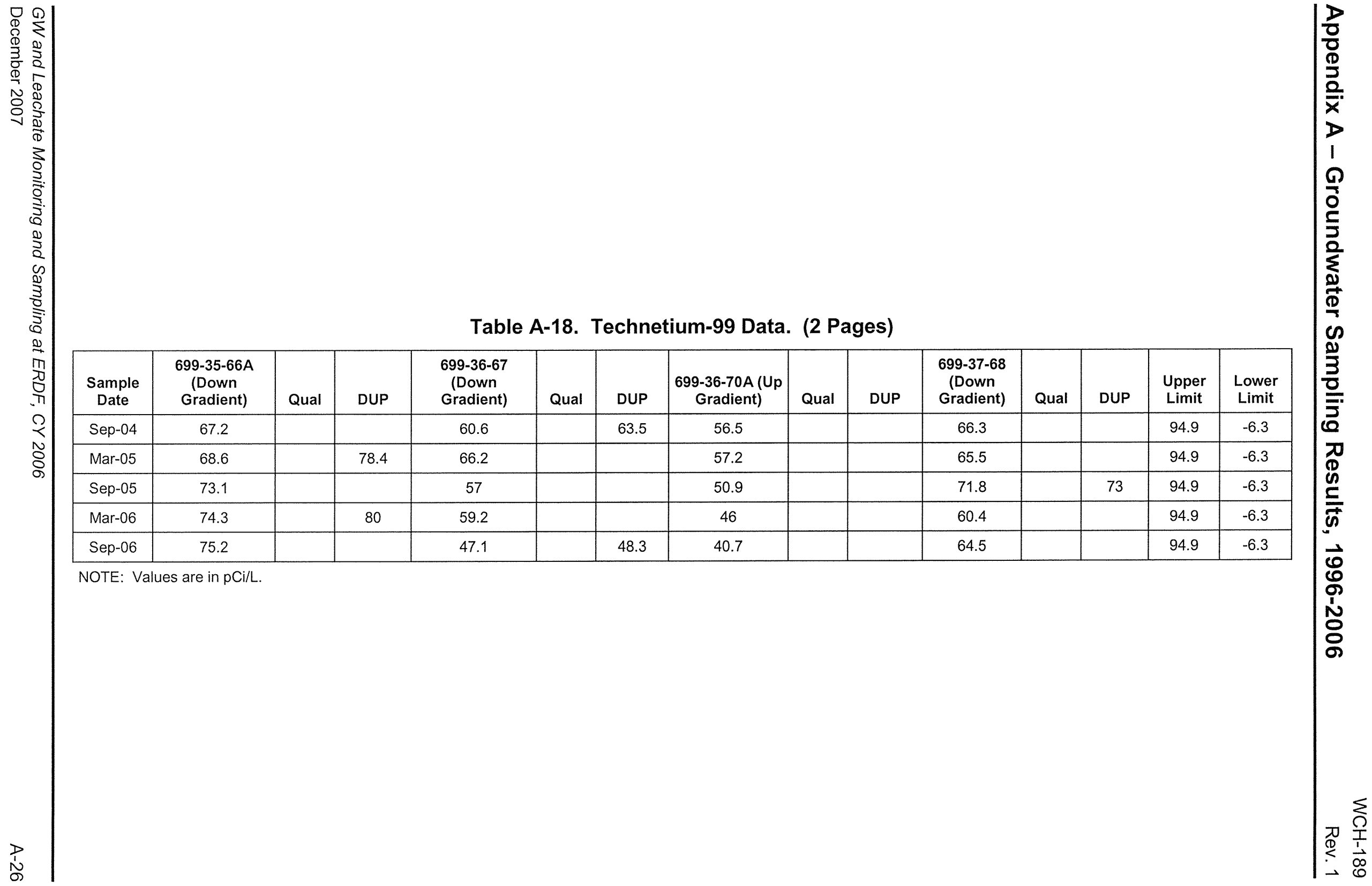


Table A-19. Radium Data.

\begin{tabular}{|c|c|c|c|c|c|c|c|c|c|c|c|c|c|c|}
\hline $\begin{array}{c}\text { Sample } \\
\text { Date }\end{array}$ & $\begin{array}{l}\text { 699-35-66A } \\
\text { (Down } \\
\text { Gradient) }\end{array}$ & Qual & DUP & $\begin{array}{l}\text { 699-36-67 } \\
\text { (Down } \\
\text { Gradient) }\end{array}$ & Qual & DUP & $\begin{array}{c}699-36-70 A \\
\text { (Up } \\
\text { Gradient) }\end{array}$ & Qual & DUP & $\begin{array}{l}\text { 699-37-68 } \\
\text { (Down } \\
\text { Gradient) }\end{array}$ & Qual & DUP & $\begin{array}{l}\text { Upper } \\
\text { Limit }\end{array}$ & $\begin{array}{l}\text { Lower } \\
\text { Limit }\end{array}$ \\
\hline Mar-96 & 0.141 & U & & 0.207 & U & & 0.521 & $J$ & & 0.276 & U & $0.235 \mathrm{~J}$ & 0.5 & -0.2 \\
\hline Sep-96 & & & & & & & & & & & & & 0.5 & -0.2 \\
\hline Mar-97 & 0.0235 & U & & 0.065 & $J$ & & 0.0577 & U & & 0.07 & $\mathrm{~J}$ & & 0.5 & -0.2 \\
\hline Sep-97 & 0.0723 & U & $0.036 \mathrm{U}$ & 0.0353 & U & & 0.123 & U & & 0.0748 & U & & 0.5 & -0.2 \\
\hline Mar-98 & 0.078 & $u$ & & 0.21 & $\mathrm{~J}$ & $0.103 \mathrm{U}$ & 0.148 & $U$ & & 0.114 & $U$ & & 0.5 & -0.2 \\
\hline Aug-98 & & & & & & & & & & & & & 0.5 & -0.2 \\
\hline Mar-99 & & & & & & & & & & & & & 0.5 & -0.2 \\
\hline Sep-99 & & & & & & & & & & & & & 0.5 & -0.2 \\
\hline Mar-00 & & & & & & & & & & & & & 0.5 & -0.2 \\
\hline Sep-00 & 0.827 & U & & 1.99 & $\mathrm{~J}$ & & -0.261 & $u$ & $0.182 U$ & & & & 0.5 & -0.2 \\
\hline Mar-01 & 0.144 & U & & 0.431 & $U$ & & -0.037 & U & & 0.033 & $U$ & $0.931 U$ & 0.5 & -0.2 \\
\hline Sep-01 & -0.387 & U & & -0.537 & $u$ & $0.506 \mathrm{U}$ & 0.675 & $u$ & & 0.18 & U & & 0.5 & -0.2 \\
\hline Mar-02 & 0.94 & $\mathrm{~J}$ & $0.599 \mathrm{U}$ & 0.063 & U & & 0.383 & $u$ & & 0.258 & $U$ & & 0.5 & -0.2 \\
\hline Sep-02 & -0.147 & U & & 0.332 & $U$ & $-0.143 U$ & 0.147 & $U$ & & -0.271 & $U$ & & 0.5 & -0.2 \\
\hline Mar-03 & 0.345 & U & & 0.474 & $U$ & & -0.392 & $u$ & & 0.637 & $U$ & & 0.5 & -0.2 \\
\hline Sep-03 & -0.63 & $U$ & $-.009 \mathrm{U}$ & 0.92 & $U$ & & 0.039 & U & & 0.039 & $U$ & & 0.5 & -0.2 \\
\hline Mar-04 & 0.232 & u & & 0.611 & u & & 0.57 & U & & 0.265 & U & $0.411 \mathrm{U}$ & 0.5 & -0.2 \\
\hline Sep-04 & -0.022 & $u$ & & -0.05 & $\mathrm{U}$ & $-0.128 \mathrm{U}$ & -0.083 & U & & -0.051 & $u$ & & 0.5 & -0.2 \\
\hline Mar-05 & 0.144 & $u$ & $-.045 \mathrm{U}$ & 0.089 & $u$ & & 0.037 & $U$ & & -0.058 & U & & 0.5 & -0.2 \\
\hline Sep-05 & 0.168 & $u$ & & 0.085 & U & & 0.059 & $u$ & & 0.036 & U & $0.04 U$ & 0.5 & -0.2 \\
\hline Mar-06 & -0.294 & U & $-0.042 \mathrm{U}$ & 0.045 & $u$ & & -0.199 & $U$ & & -0.194 & $U$ & & 0.5 & -0.2 \\
\hline Sep-06 & -0.215 & U & & -0.117 & $U$ & $0.073 \mathrm{U}$ & -0.327 & $u$ & & 0.06 & $U$ & & 0.5 & -0.2 \\
\hline
\end{tabular}

NOTE: Values are in $\mathrm{pCi} / \mathrm{L}$. 


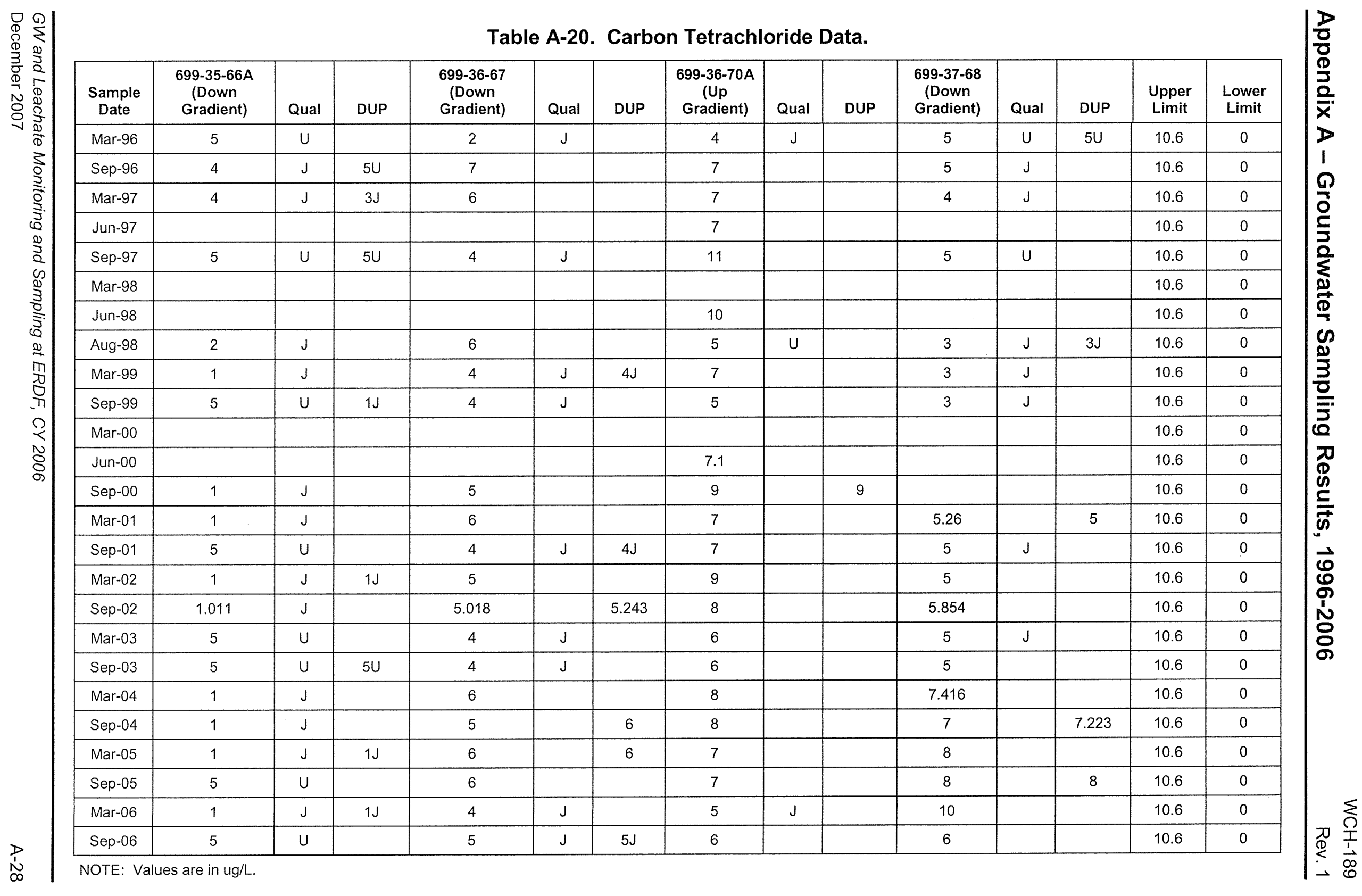


Table A-21. Nitrogen in Nitrate/Nitrite Data.

\begin{tabular}{|c|c|c|c|c|c|c|c|c|c|c|c|c|c|c|}
\hline $\begin{array}{c}\text { Sample } \\
\text { Date }\end{array}$ & $\begin{array}{l}\text { 699-35-66A } \\
\text { (Down } \\
\text { Gradient) }\end{array}$ & Qual & DUP & $\begin{array}{c}\text { 699-36-67 } \\
\text { (Down } \\
\text { Gradient) }\end{array}$ & Qual & DUP & \begin{tabular}{|c|}
$699-36-70 \mathrm{~A}$ \\
(Up \\
Gradient) \\
\end{tabular} & Qual & DUP & $\begin{array}{c}\text { 699-37-68 } \\
\text { (Down } \\
\text { Gradient) }\end{array}$ & Qual & DUP & $\begin{array}{c}\text { Upper } \\
\text { Limit } \\
\end{array}$ & $\begin{array}{l}\text { Lower } \\
\text { Limit }\end{array}$ \\
\hline Sep-95 & & & & & & & 36.6 & & & & & & 51.5 & -8.7 \\
\hline Mar-96 & 4.58 & & & 20.2 & & & 31.9 & & & 35.6 & & 36.5 & 51.5 & -8.7 \\
\hline Sep-96 & 4.19 & & & 20.6 & & & 26.1 & & & 33.7 & & & 51.5 & -8.7 \\
\hline Mar-97 & 0.419 & & 40 & 22.6 & & & 21.3 & & & 34.1 & & & 51.5 & -8.7 \\
\hline Sep-97 & 4.13 & & 4.19 & 18.9 & & & 24.6 & & & 35.4 & & & 51.5 & -8.7 \\
\hline Mar-98 & 4.62 & D & & 20.4 & $D$ & $20.1 \mathrm{D}$ & 25.3 & $D$ & & 34.3 & $D$ & & 51.5 & -8.7 \\
\hline Aug-98 & 4.14 & & & 24 & & & 26.3 & & & 35.2 & & 34.5 & 51.5 & -8.7 \\
\hline Mar-99 & 4.53 & & & 20.8 & & 20.6 & 24.6 & & & 31.8 & & & 51.5 & -8.7 \\
\hline Sep-99 & 4.6 & & 4.5 & 20 & & & 23.7 & & & 33 & & & 51.5 & -8.7 \\
\hline Mar-00 & & & & & & & & & & & & & 51.5 & -8.7 \\
\hline Sep-00 & 4.7 & & & 19.1 & & & 24.6 & & 23.2 & & & & 51.5 & -8.7 \\
\hline Mar-01 & 5.5 & & & 19.9 & & & 24.7 & & & 31.3 & & 32.2 & 51.5 & -8.7 \\
\hline Sep-01 & 4.6 & & & 17.3 & & 17.6 & 23 & & & 29.3 & & & 51.5 & -8.7 \\
\hline Mar-02 & 4.6 & & 4.5 & 16.3 & & & 18.9 & & & 27.9 & & & 51.5 & -8.7 \\
\hline Sep-02 & 4.48 & & & 15.8 & & 15.8 & 19 & & & 26.6 & & & 51.5 & -8.7 \\
\hline Mar-03 & 4.8 & & & 17 & & & 21.4 & & & 29.7 & & & 51.5 & -8.7 \\
\hline Sep-03 & 5.1 & $D$ & $5.1 \mathrm{D}$ & 15.9 & $D$ & & 19.3 & $D$ & & 29.2 & $D$ & & 51.5 & -8.7 \\
\hline Mar-04 & 4.8 & D & & 14.4 & $D$ & & 16.8 & D & & 32.4 & $D$ & $26 \mathrm{D}$ & 51.5 & -8.7 \\
\hline Sep-04 & 4.9 & & & 15.3 & & 15.8 & 16.8 & & & 26.8 & & & 51.5 & -8.7 \\
\hline Mar-05 & 5.1 & & 5.1 & 14.3 & & & 15.6 & & & 25.8 & & & 51.5 & -8.7 \\
\hline Sep-05 & 7.72 & $\mathrm{D}$ & & 12.5 & $D$ & & 14.4 & $D$ & & 24.6 & $\mathrm{D}$ & $24 \mathrm{D}$ & 51.5 & -8.7 \\
\hline Mar-06 & 4.6 & $D$ & $4.6 \mathrm{D}$ & 12.9 & $D$ & & 13.8 & $D$ & & 23.7 & $D$ & & 51.5 & -8.7 \\
\hline Sep-06 & 5.3 & & & 13.4 & $D$ & $13.2 \mathrm{D}$ & 13.3 & & & 22.8 & D & & 51.5 & -8.7 \\
\hline
\end{tabular}


Table A-22. Total Organic Halides.

\begin{tabular}{|c|c|c|c|c|c|c|c|c|c|c|c|c|c|c|}
\hline $\begin{array}{c}\text { Sample } \\
\text { Date }\end{array}$ & $\begin{array}{c}\text { 699-35-66A } \\
\text { (Down } \\
\text { Gradient) }\end{array}$ & Qual & DUP & $\begin{array}{c}699-36-67 \\
\text { (Down } \\
\text { Gradient) }\end{array}$ & Qual & DUP & $\begin{array}{c}\text { 699-36-70A } \\
\text { (Up } \\
\text { Gradient) } \\
\end{array}$ & Qual & DUP & $\begin{array}{c}\text { 699-37-68 } \\
\text { (Down } \\
\text { Gradient) }\end{array}$ & Qual & DUP & $\begin{array}{l}\text { Upper } \\
\text { Limit }\end{array}$ & $\begin{array}{c}\text { Lower } \\
\text { Limit } \\
\end{array}$ \\
\hline Mar-96 & 6.6 & $\mathrm{~J}$ & & 10.5 & $\mathrm{~J}$ & & 5.6 & $\mathrm{~J}$ & & 6.6 & $\mathrm{~J}$ & 5 & 9.5 & 1.2 \\
\hline Sep-96 & 5 & U & & 5 & U & & 5 & U & & 5 & U & & 9.5 & 1.2 \\
\hline Mar-97 & 5 & U & & 5 & U & & 2.9 & & & 5 & $U$ & & 9.5 & 1.2 \\
\hline Jun-97 & & & & & & & 11.7 & & & & & & 9.5 & 1.2 \\
\hline Sep-97 & 6.05 & & $4.62 \mathrm{U}$ & 7.05 & & & 4.62 & U & & 5 & U & & 9.5 & 1.2 \\
\hline Mar-98 & 4.62 & U & & 4.62 & $u$ & $4.62 \mathrm{U}$ & 4.62 & U & & 4.62 & U & & 9.5 & 1.2 \\
\hline Aug-98 & 5.9 & & & 5.85 & & & 6.7 & & & 5 & $U$ & $5 U$ & 9.5 & 1.2 \\
\hline Mar-99 & 24 & $U$ & & 12 & $U$ & $24 U$ & 34.5 & & & 14.3 & & & 9.5 & 1.2 \\
\hline Sep-99 & 128 & & $12 \mathrm{U}$ & 206 & & & 12 & U & & 12 & U & & 9.5 & 1.2 \\
\hline Jan-00 & & & & & & & 14 & & & & & & 9.5 & 1.2 \\
\hline Mar-00 & & & & & & & & & & & & & 9.5 & 1.2 \\
\hline Jun-00 & & & & & & & 4.4 & B & & & & & 9.5 & 1.2 \\
\hline Sep-00 & 206 & & & 271 & & & 180 & & 181 & & & & 9.5 & 1.2 \\
\hline Dec-00 & & & & & & & 10.6 & & & & & & 9.5 & 1.2 \\
\hline Mar-01 & 17.1 & U & & 20 & U & & 20 & U & & 20 & U & $20 U$ & 9.5 & 1.2 \\
\hline Sep-01 & 6.5 & $U$ & & 8.7 & $U$ & $7.4 \mathrm{U}$ & 6.5 & $U$ & & 6.6 & U & & 9.5 & 1.2 \\
\hline Dec-01 & & & & & & & 13.2 & & & & & & 9.5 & 1.2 \\
\hline Mar-02 & 5.2 & U & 6.1 & 9.3 & & & 9.5 & & & 5.2 & U & & 9.5 & 1.2 \\
\hline Sep-02 & 10.5 & & & 5.6 & & $5.2 \mathrm{U}$ & 8.5 & & & 60.6 & & & 9.5 & 1.2 \\
\hline Mar-03 & 5.2 & U & & 6.3 & & & 5.3 & & & 5.2 & U & & 9.5 & 1.2 \\
\hline Sep-03 & 5.2 & U & $5.2 U$ & 6.2 & & & 6.8 & & & 6.3 & & & 9.5 & 1.2 \\
\hline Mar-04 & 6.7 & & & 5.7 & & & 9.8 & & & 5.2 & U & 6.4 & 9.5 & 1.2 \\
\hline Sep-04 & 5.2 & $U$ & & 5.2 & $U$ & $5.2 \mathrm{U}$ & 6.7 & & & 5.2 & U & & 9.5 & 1.3 \\
\hline Mar-05 & 5 & U & 6.3 & 8.1 & & & 12.8 & & & 11.4 & & & 9.5 & 1.3 \\
\hline Sep-05 & 5 & u & & 8.83 & & & 12.2 & & & 7.46 & & 5.51 & 9.5 & 1.3 \\
\hline Mar-06 & 5.2 & $U C$ & $15.9 \mathrm{C}$ & 5.2 & UC & & 9.2 & C & & 10.6 & D & & 9.5 & 1.3 \\
\hline Sep-06 & 16.9 & & & 5 & U & $5 U$ & 6.1 & & & 38.9 & & & 9.5 & 1.3 \\
\hline
\end{tabular}


Table A-23. Total Dissolved Solids Data.

\begin{tabular}{|c|c|c|c|c|c|c|c|c|c|c|c|c|c|c|}
\hline $\begin{array}{c}\text { Sample } \\
\text { Date }\end{array}$ & $\begin{array}{l}\text { 699-35-66A } \\
\text { (Down } \\
\text { Gradient) }\end{array}$ & Qual & DUP & $\begin{array}{l}\text { 699-36-67 } \\
\text { (Down } \\
\text { Gradient) }\end{array}$ & Qual & DUP & $\begin{array}{c}\text { 699-36-70A } \\
\text { (Up } \\
\text { Gradient) }\end{array}$ & Qual & DUP & $\begin{array}{l}\text { 699-37-68 } \\
\text { (Down } \\
\text { Gradient) }\end{array}$ & Qual & DUP & $\begin{array}{l}\text { Upper } \\
\text { Limit }\end{array}$ & $\begin{array}{l}\text { Lower } \\
\text { Limit }\end{array}$ \\
\hline Mar-96 & 254 & & & 340 & & & 384 & & & 401 & & 420 & 573.6 & 170.9 \\
\hline Sep-96 & 236 & & & 367 & & & 411 & & & 457 & & & 573.6 & 170.9 \\
\hline Mar-97 & 283 & & 279 & 404 & & & 390 & & & 514 & & & 573.6 & 170.9 \\
\hline Jun-97 & & & & & & & 398 & & & & & & 573.6 & 170.9 \\
\hline Sep-97 & 277 & & 278 & 377 & & & 401 & & & 463 & & & 573.6 & 170.9 \\
\hline Dec-97 & & & & & & & 379 & & & & & & 573.6 & 170.9 \\
\hline Mar-98 & 322 & & & 320 & & 309 & 327 & & & 456 & & & 573.6 & 170.9 \\
\hline Jun-98 & & & & & & & 472 & & & & & & 573.6 & 170.9 \\
\hline Aug-98 & 296 & & & 406 & & & 422 & & & 491 & & 507 & 573.6 & 170.9 \\
\hline Dec-98 & & & & & & & 344 & & & & & & 573.6 & 170.9 \\
\hline Mar-99 & 280 & & & 380 & & 400 & 390 & & 406 & 440 & & & 573.6 & 170.9 \\
\hline Jun-99 & & & & & & & 407 & & & & & & 573.6 & 170.9 \\
\hline Sep-99 & 270 & & 280 & 370 & & & 410 & & & 470 & & & 573.6 & 170.9 \\
\hline Jan-00 & & & & & & & 355 & & & & & & 573.6 & 170.9 \\
\hline Mar-00 & & & & & & & & & & & & & 573.6 & 170.9 \\
\hline Jun-00 & & & & & & & 434 & & & & & & 573.6 & 170.9 \\
\hline Sep-00 & 270 & & & 340 & & & 550 & & 520 & & & & 573.6 & 170.9 \\
\hline Mar-01 & 278 & & & 407 & & & 400 & & & 349 & & 436 & 573.6 & 170.9 \\
\hline Sep-01 & 305 & & & 384 & & 391 & 420 & & & 535 & & & 573.6 & 170.9 \\
\hline Mar-02 & 265 & & 258 & 333 & & & 358 & & & 430 & & & 573.6 & 170.9 \\
\hline Sep-02 & 276 & & & 326 & & 328 & 344 & & & 446 & & & 573.6 & 170.9 \\
\hline Mar-03 & 260 & & & 337 & & & 349 & & & 407 & & & 573.6 & 170.9 \\
\hline Sep-03 & 269 & & 271 & 361 & & & 381 & & & 5 & U & & 573.6 & 170.9 \\
\hline Mar-04 & 262 & & & 323 & & & 326 & & & 438 & & 442 & 573.6 & 170.9 \\
\hline Sep-04 & 262 & & & 331 & & 330 & 355 & & & 392 & & & 573.6 & 170.9 \\
\hline Mar-05 & 205 & & 253 & 278 & & & 339 & & & 386 & & & 573.6 & 170.9 \\
\hline Sep-05 & 292 & & & 387 & & & 403 & & & 460 & & 500 & 573.6 & 170.9 \\
\hline Mar-06 & 274 & & 269 & 314 & & & 302 & & & 391 & & & 573.6 & 170.9 \\
\hline Sep-06 & 270 & & & 464 & & 409 & 311 & & & 521 & & & 573.6 & 170.9 \\
\hline
\end{tabular}


Table A-24. Turbidity Data. (2 Pages)

\begin{tabular}{|c|c|c|c|c|c|c|c|c|c|c|c|c|c|c|}
\hline $\begin{array}{c}\text { Sample } \\
\text { Date }\end{array}$ & $\begin{array}{l}\text { 699-35-66A } \\
\text { (Down } \\
\text { Gradient) }\end{array}$ & Qual & DUP & $\begin{array}{l}\text { 699-36-67 } \\
\text { (Down } \\
\text { Gradient) }\end{array}$ & Qual & DUP & $\begin{array}{c}\text { 699-36-70A } \\
\text { (Up } \\
\text { Gradient) }\end{array}$ & Qual & DUP & $\begin{array}{l}\text { 699-37-68 } \\
\text { (Down } \\
\text { Gradient) }\end{array}$ & Qual & DUP & $\begin{array}{l}\text { Upper } \\
\text { Limit }\end{array}$ & $\begin{array}{l}\text { Lower } \\
\text { Limit }\end{array}$ \\
\hline Jun-95 & & & & & & & 5.02 & & & & & & 50 & -34.9 \\
\hline Sep-95 & & & & & & & 5.01 & & & & & & 50 & -34.9 \\
\hline Mar-96 & 0.34 & $\mathrm{~J}$ & & 0.3 & $\mathrm{~J}$ & & 0.26 & $\mathrm{~J}$ & & 3.21 & $\mathrm{~J}$ & $1.48 \mathrm{~J}$ & 50 & -34.9 \\
\hline Sep-96 & & & & & & & & & & & & & 50 & -34.9 \\
\hline Mar-97 & 0.71 & & & 8.91 & & & 0.84 & & & 60.6 & & & 50 & -34.9 \\
\hline Jun-97 & & & & & & & 1.78 & & & & & & 50 & -34.9 \\
\hline Sep-97 & 1.9 & & & 14.4 & & & 1.33 & & & 4.56 & & & 50 & -34.9 \\
\hline Dec-97 & & & & & & & 1.38 & & & & & & 50 & -34.9 \\
\hline Mar-98 & 1.65 & & & 23.4 & & & 3.52 & & & 4.85 & & & 50 & -34.9 \\
\hline Jun-98 & & & & & & & 3.99 & & & & & & 50 & -34.9 \\
\hline Aug-98 & 1.29 & & & 90.5 & & & & & & 2.95 & & & 50 & -34.9 \\
\hline Dec-98 & & & & & & & 2.62 & & & & & & 50 & -34.9 \\
\hline Mar-99 & & & & 52.6 & & & 4.54 & & & & & & 50 & -34.9 \\
\hline Jun-99 & & & & & & & 3.25 & & & & & & 50 & -34.9 \\
\hline Sep-99 & 2.29 & & & 87.2 & & & 2.68 & & & & & & 50 & -34.9 \\
\hline Jan-00 & & & & & & & 4.12 & & & & & & 50 & -34.9 \\
\hline Mar-00 & & & & & & & & & & & & & 50 & -34.9 \\
\hline Jun-00 & & & & & & & 1.63 & & & & & & 50 & -34.9 \\
\hline Sep-00 & 2.3 & & & 142 & & & 2.6 & & & & & & 50 & -34.9 \\
\hline Dec-00 & & & & & & & 2.41 & & & & & & 50 & -34.9 \\
\hline Mar-01 & 1.71 & & & 38.2 & & & 1.06 & & & 16.7 & & & 50 & -34.9 \\
\hline Jun-01 & & & & & & & 1.71 & & & & & & 50 & -34.9 \\
\hline Sep-01 & 1.54 & & & 3.35 & & & 1.17 & & & 6.62 & & & 50 & -34.9 \\
\hline Dec-01 & & & & & & & 4.12 & & & & & & 50 & -34.9 \\
\hline Mar-02 & 1.85 & & & 11.1 & & & 5 & & & 7.4 & & & 50 & -34.9 \\
\hline Sep-02 & 2.2 & & & 5.6 & & & 4.7 & & & 6.7 & & & 50 & -34.9 \\
\hline Mar-03 & 1.86 & & & 962 & & & 1.29 & & & 15 & & & 50 & -34.9 \\
\hline Sep-03 & 2.41 & & & 41.6 & & & 2.68 & & & 49.7 & & & 50 & -34.9 \\
\hline
\end{tabular}




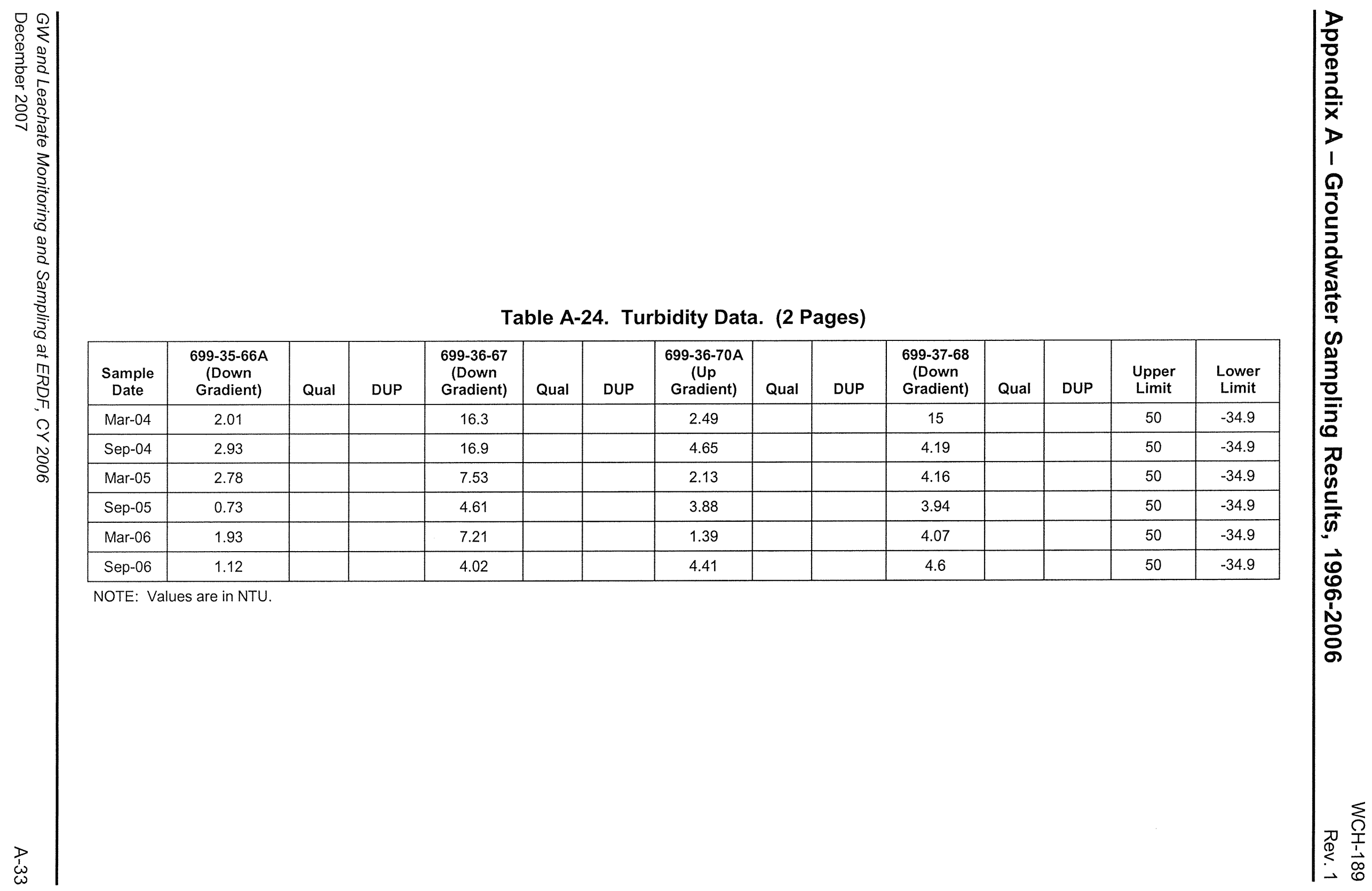




\begin{tabular}{|c|c|c|c|c|c|c|c|c|c|c|c|c|c|c|}
\hline $\begin{array}{c}\text { Sample } \\
\text { Date }\end{array}$ & $\begin{array}{l}\text { 699-35-66A } \\
\text { (Down } \\
\text { Gradient) }\end{array}$ & Qual & DUP & $\begin{array}{c}\text { 699-36-67 } \\
\text { (Down } \\
\text { Gradient) }\end{array}$ & Qual & DUP & $\begin{array}{c}\text { 699-36-70A } \\
\text { (Up } \\
\text { Gradient) }\end{array}$ & Qual & DUP & $\begin{array}{l}\text { 699-37-68 } \\
\text { (Down } \\
\text { Gradient) }\end{array}$ & Qual & DUP & $\begin{array}{l}\text { Upper } \\
\text { Limit }\end{array}$ & $\begin{array}{l}\text { Lower } \\
\text { Limit }\end{array}$ \\
\hline Jan-95 & & & & & & & 6.4 & & & & & & 8 & 7.5 \\
\hline Jun-95 & & & & & & & 7 & & & & & & 8 & 7.5 \\
\hline Sep-95 & & & & & & & 7.65 & & & & & & 8 & 7.5 \\
\hline Jan-96 & & & & 7.71 & & & & & & 7.68 & & & 8 & 7.5 \\
\hline Mar-96 & 7.66 & & & & & & 7.8 & & & & & & 8 & 7.5 \\
\hline Sep-96 & & & & & & & 7.7 & & & & & & 8 & 7.5 \\
\hline Mar-97 & 7.82 & & & 7.68 & & & 7.67 & & & 7.64 & & & 8 & 7.5 \\
\hline Jun-97 & & & & & & & 7.75 & & & & & & 8 & 7.5 \\
\hline Sep-97 & 7.86 & & & 7.86 & & & 7.76 & & & 7.74 & & & 8 & 7.5 \\
\hline Dec-97 & & & & & & & 7.81 & & & & & & 8 & 7.5 \\
\hline Mar-98 & 7.86 & & & 7.8 & & & 7.64 & & & 7.71 & & & 8 & 7.5 \\
\hline Jun-98 & & & & & & & 7.72 & & & & & & 8 & 7.5 \\
\hline Aug-98 & 7.95 & & & 8.31 & & & 7.95 & & & 7.77 & & & 8 & 7.5 \\
\hline Dec-98 & & & & & & & 7.8 & & & & & & 8 & 7.5 \\
\hline Mar-99 & & & & 7.72 & & & 7.71 & & & & & & 8 & 7.5 \\
\hline Jun-99 & & & & & & & 7.61 & & & & & & 8 & 7.5 \\
\hline Sep-99 & 7.95 & & & 7.69 & & & 7.82 & & & & & & 8 & 7.5 \\
\hline Jan-00 & & & & & & & 7.77 & & & & & & 8 & 7.5 \\
\hline Mar-00 & & & & & & & & & & & & & 8 & 7.5 \\
\hline Jun-00 & & & & & & & 7.71 & & & & & & 8 & 7.5 \\
\hline Sep-00 & 7.9 & & & 7.7 & & & 7.8 & & & & & & 8 & 7.5 \\
\hline Dec-00 & & & & & & & 7.75 & & & & & & 8 & 7.5 \\
\hline Mar-01 & 8.56 & & & 7.7 & & & 7.84 & & & 7.74 & & & 8 & 7.5 \\
\hline Jun-01 & & & & & & & 7.68 & & & & & & 8 & 7.5 \\
\hline Sep-01 & 7.77 & & & 7.7 & & & 7.7 & & & 7.78 & & & 8 & 7.5 \\
\hline Dec-01 & & & & & & & 7.74 & & & & & & 8 & 7.5 \\
\hline Mar-02 & 7.89 & & & 7.83 & & & 7.73 & & & 7.8 & & & 8 & 7.5 \\
\hline Sep-02 & 7.9 & & & 7.8 & & & 7.7 & & & 7.8 & & & 8 & 7.5 \\
\hline
\end{tabular}




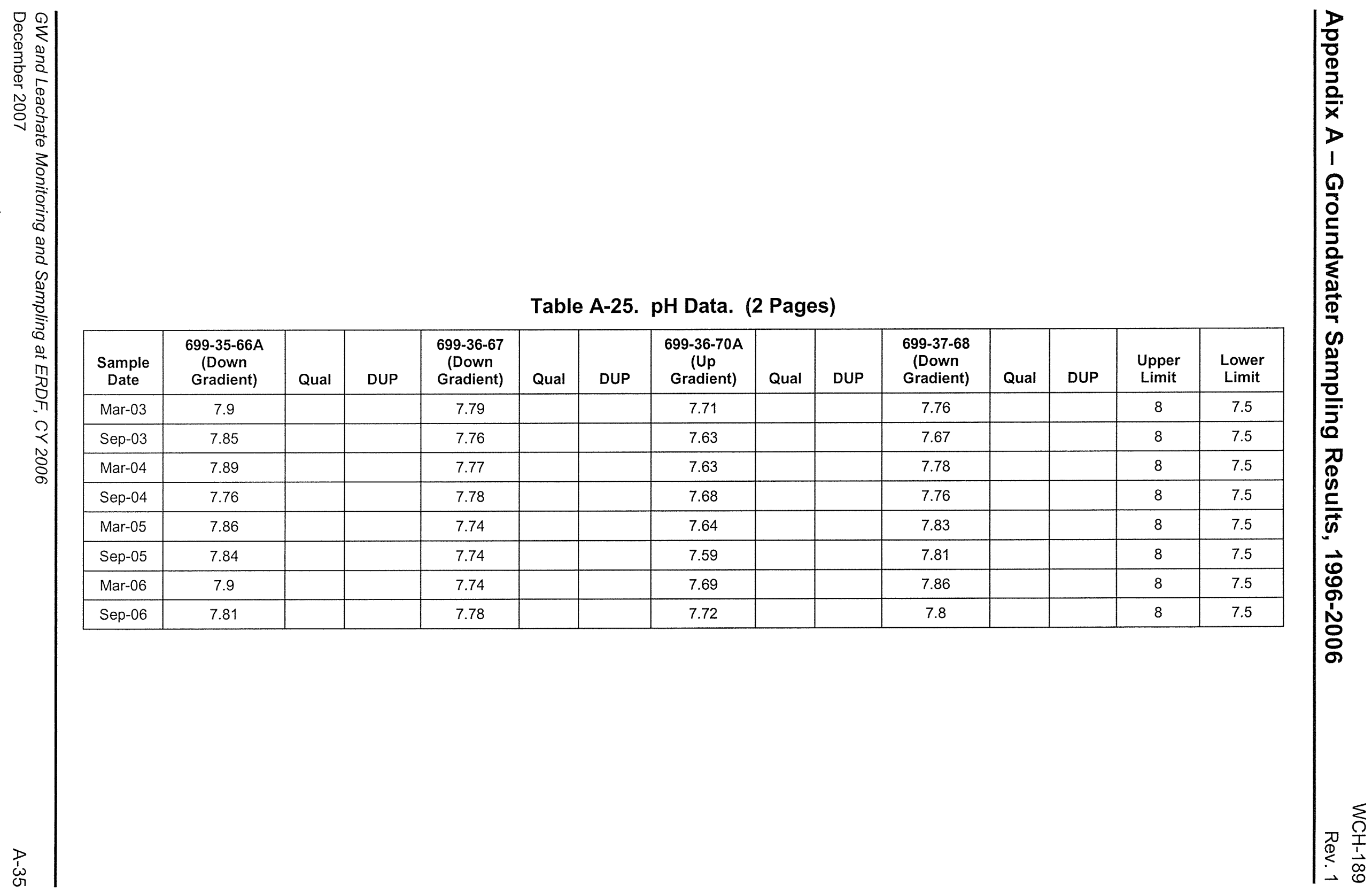




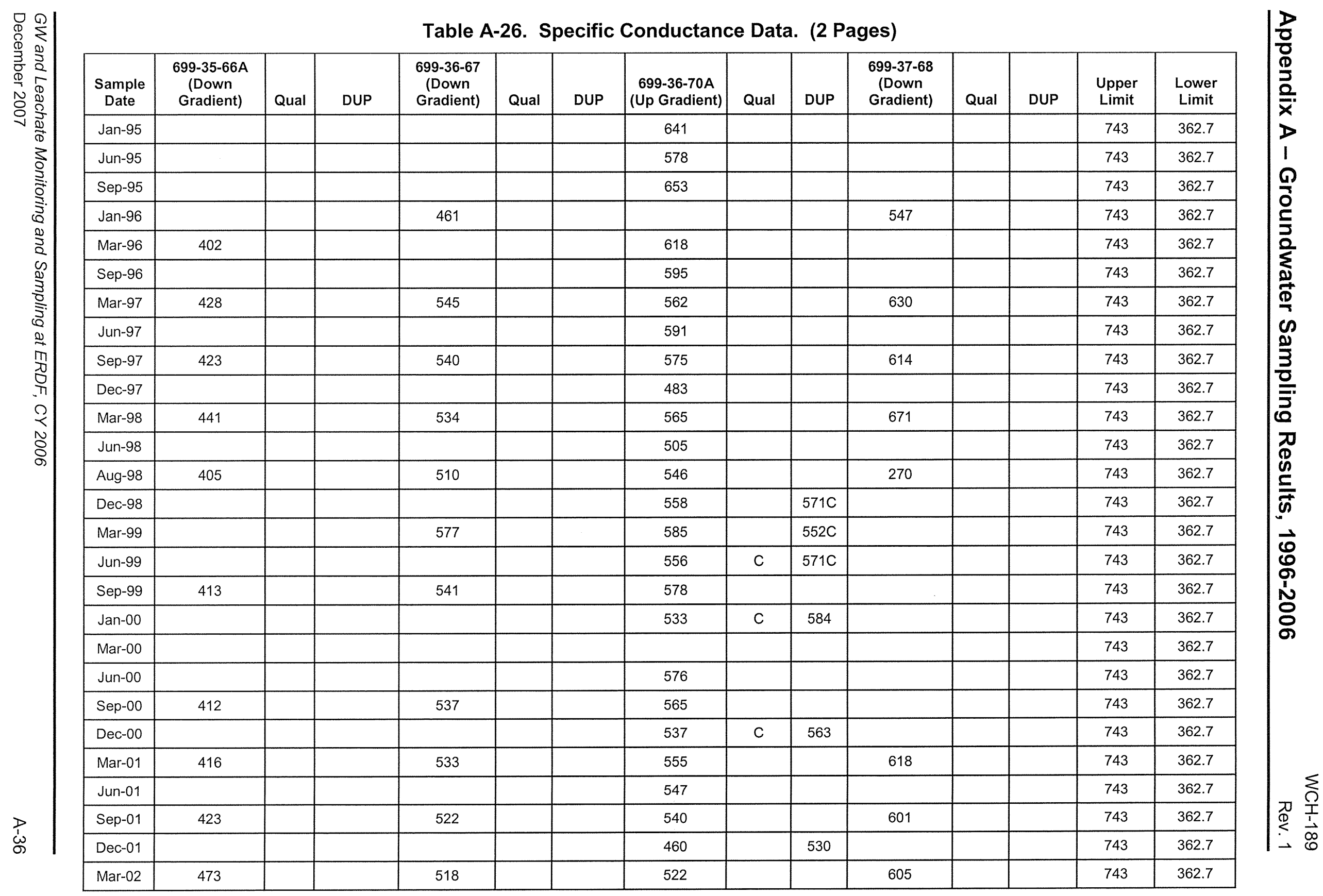




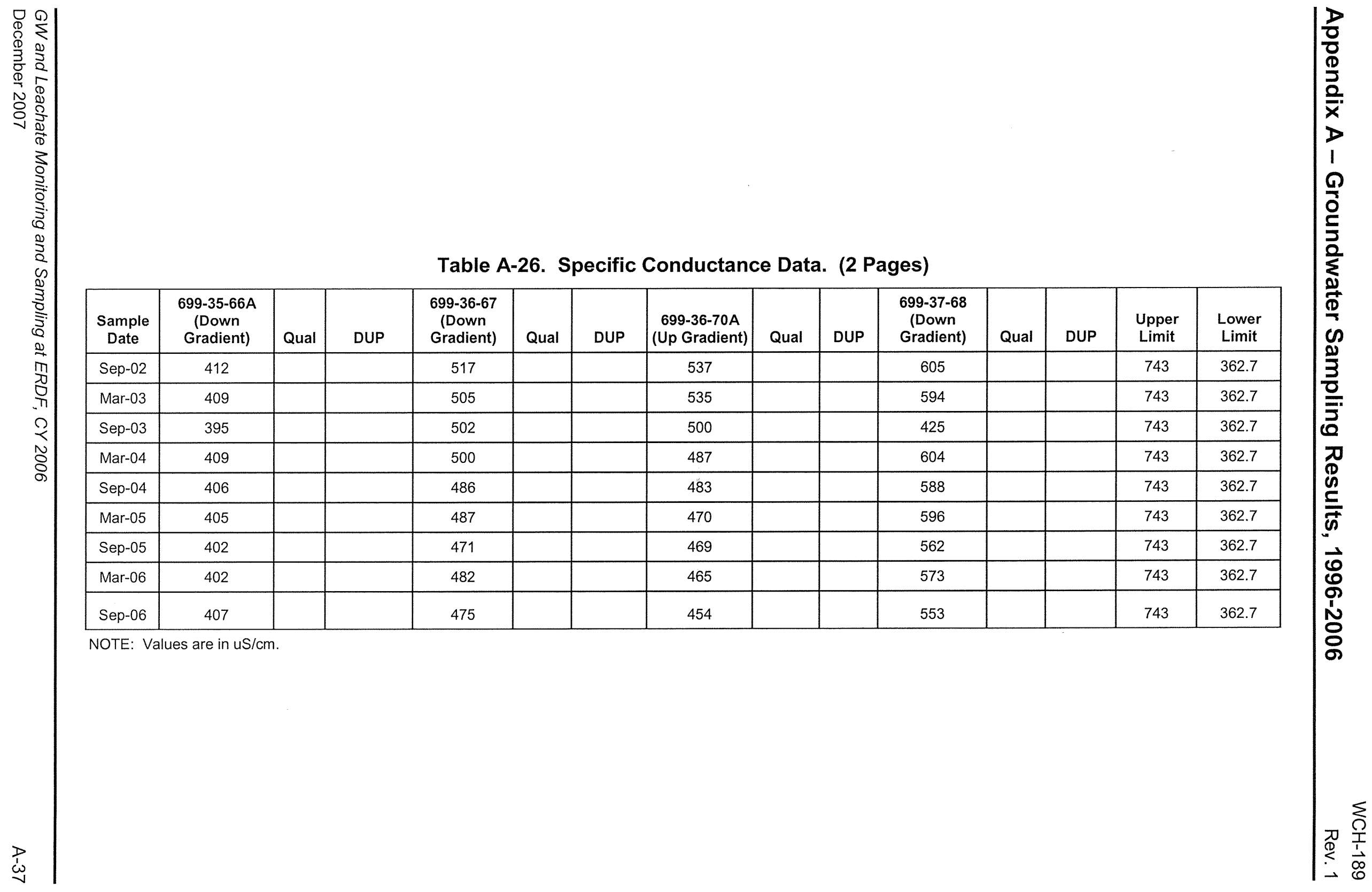




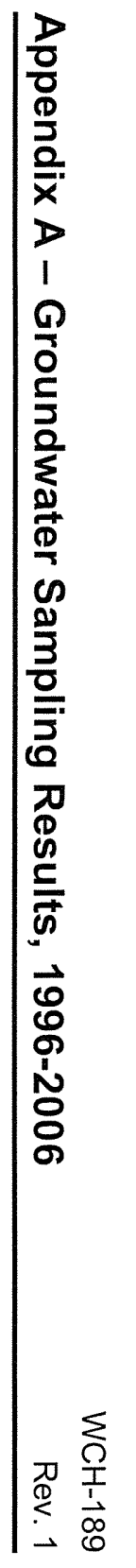




\section{APPENDIX B}

GROUNDWATER SAMPLING TRENDS, 1996-2006 
WCH-189

Rev. 1

GW and Leachate Monitoring and Sampling at ERDF, CY 2006 
Figure B-1 Arsenic (Filtered)

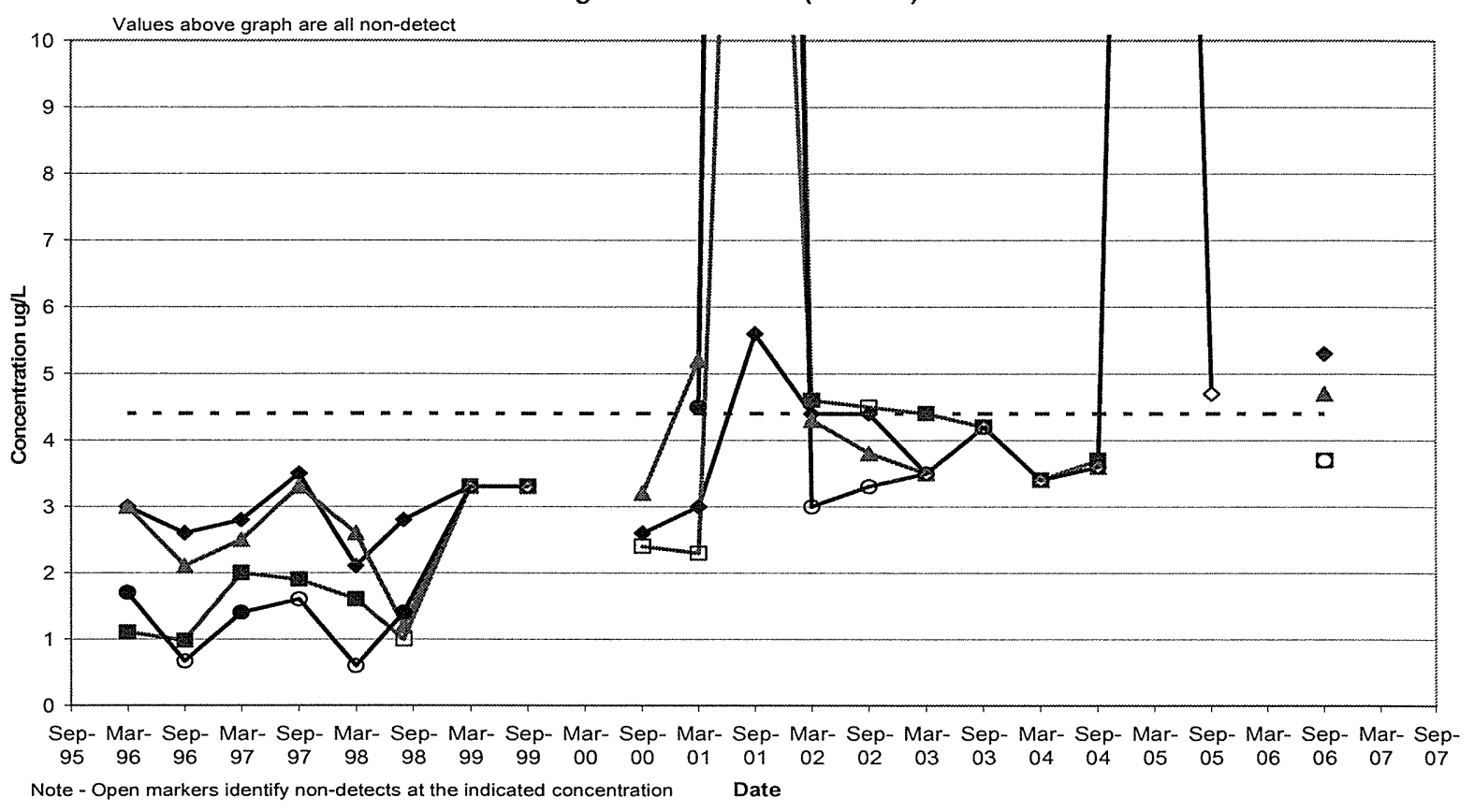

\begin{tabular}{lll}
$\longrightarrow \longrightarrow$ 699-35-66A (Down Gradient) & - 699-36-67 (Down Gradient) & - 699-36-70A (Up Gradient) \\
$\longrightarrow$ 699-37-68 (Down Gradient) & -- Upper Limt & Lower Limit <0 - set at 0 \\
\hline
\end{tabular}


Figure B-2 Barium (Filtered)

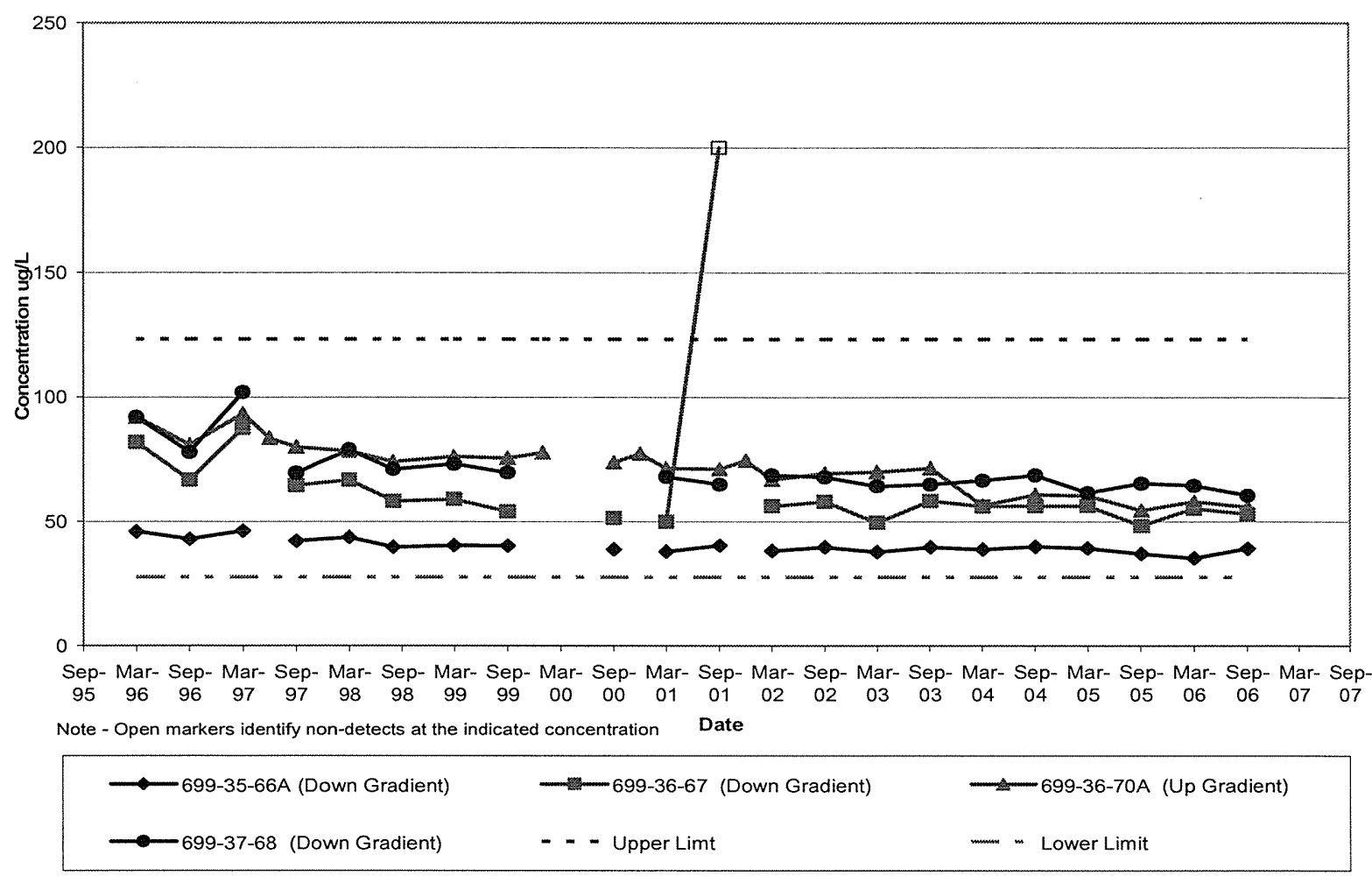


Figure B-3 Chromium (Filtered)

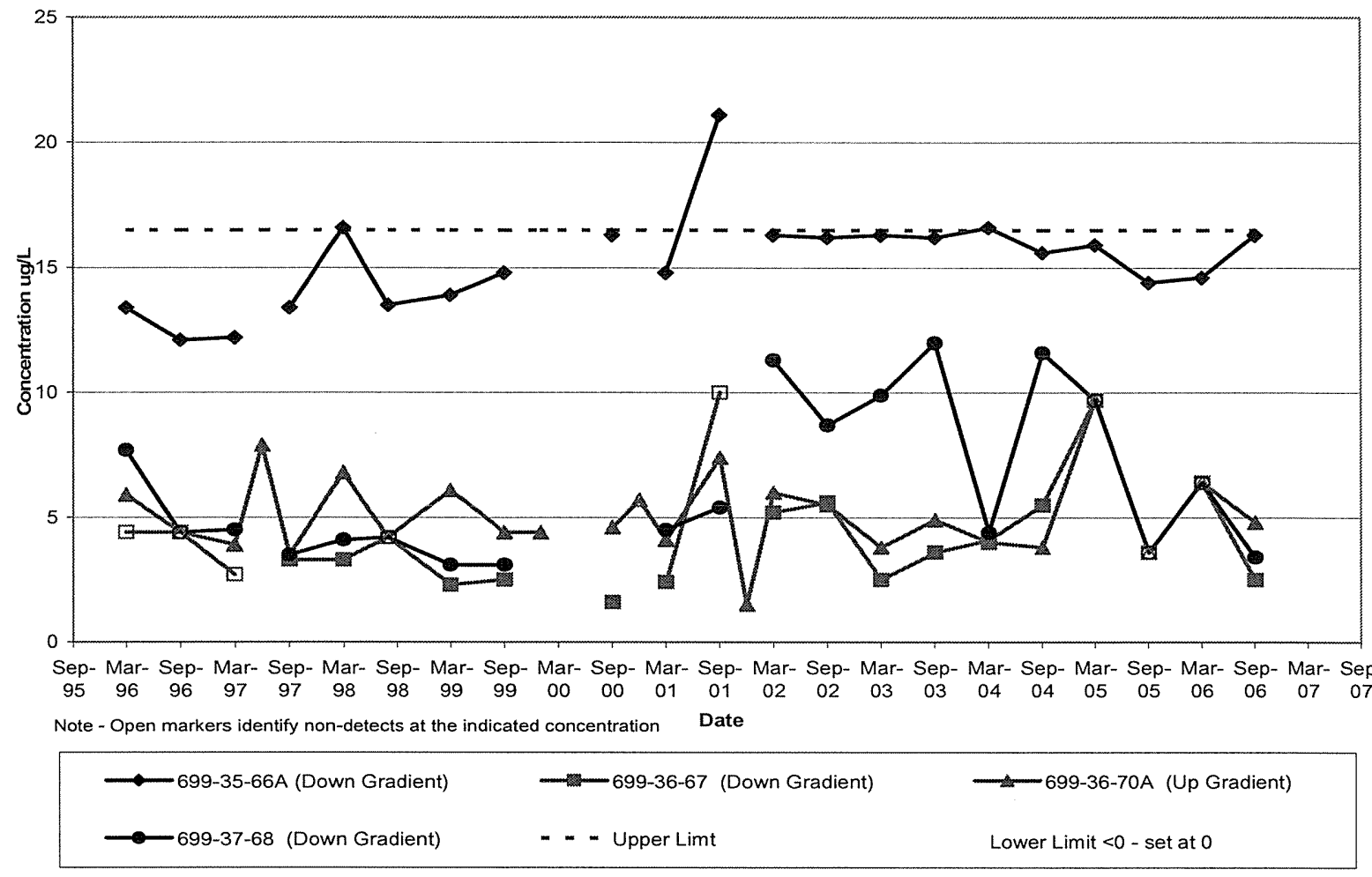


Figure B-4 Lead (Filtered)

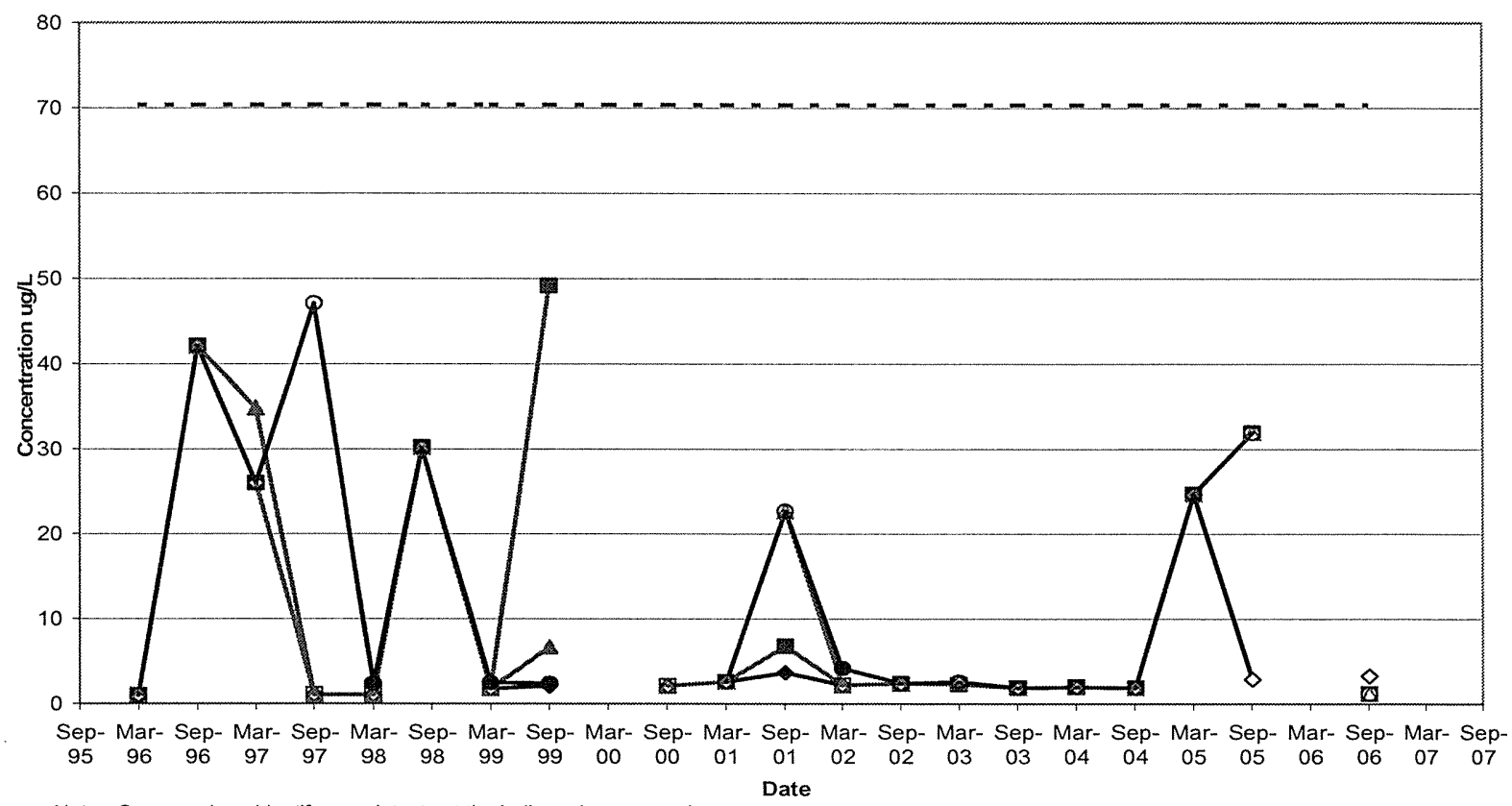

Note - Open markers identify non-detects at the indicated concentration

\begin{tabular}{lll}
\hline$-699-35-66 \mathrm{~A}$ (Down Gradient) & $-699-36-67$ (Down Gradient) & 699-36-70A (Up Gradient) \\
$-699-37-68$ (Down Gradient) & -- Upper Limt & Lower Limit <0 - set at 0 \\
\hline
\end{tabular}


Figure B-5 Selenium (Filtered)

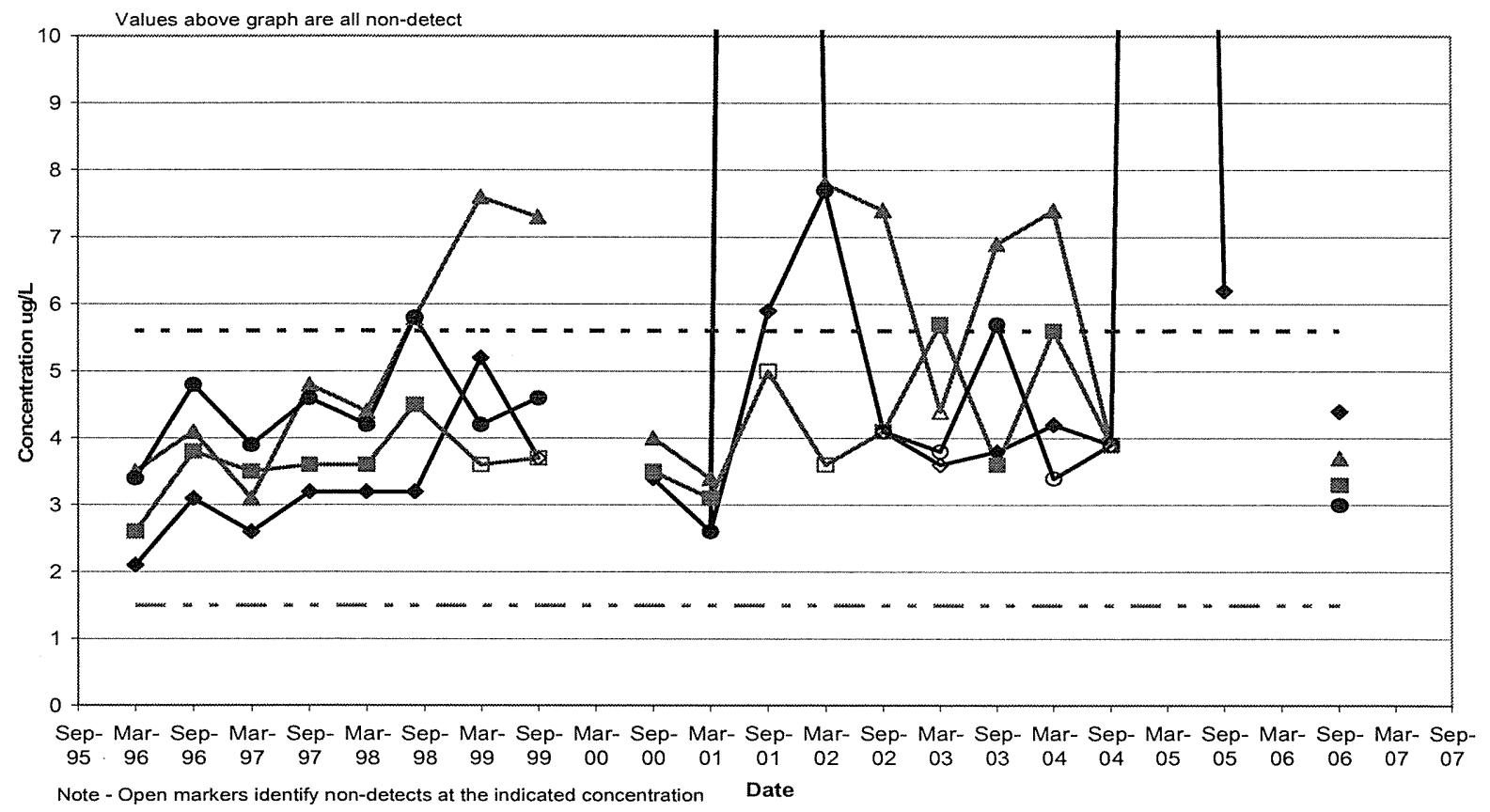

\begin{tabular}{lll}
\hline$\rightarrow$ 699-35-66A (Down Gradient) & - 699-36-67 (Down Gradient) & 699-36-70A (Up Gradient) \\
$\rightarrow$ 699-37-68 (Down Gradient) & -- Upper Limt & - Lower Limit \\
\hline
\end{tabular}


Figure B-6 Uranium (Filtered)

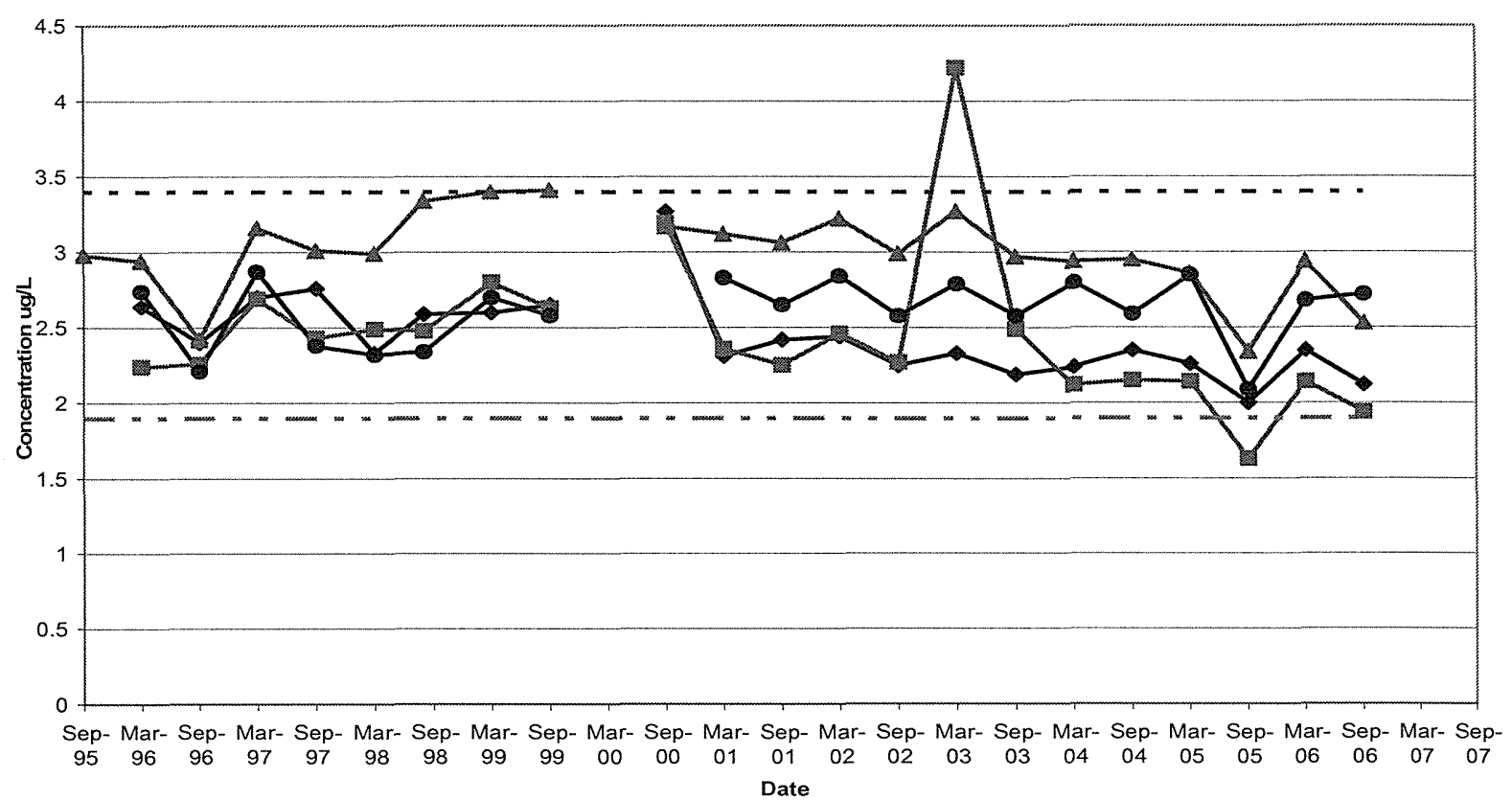

\begin{tabular}{|c|c|c|}
\hline -699-35-66A (Down Gradient) & $-699-36-67$ (Down Gradient) & $-4-699-36-70 A$ (Up Gradient) \\
\hline 9-37-68 (Down Gradient) & Upper Limt & Lower Limit \\
\hline
\end{tabular}




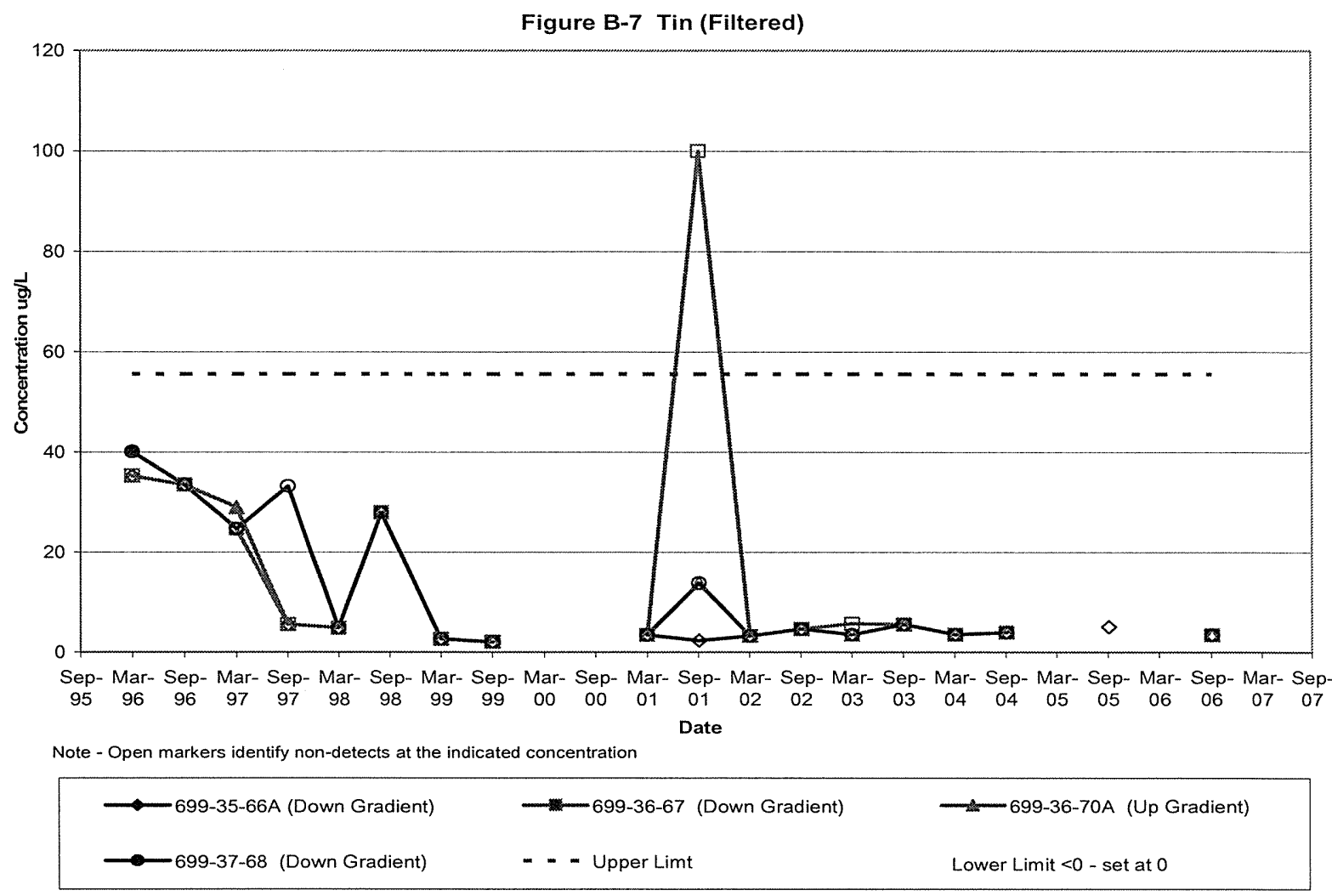


Figure B-8 Vanadium (Filtered)

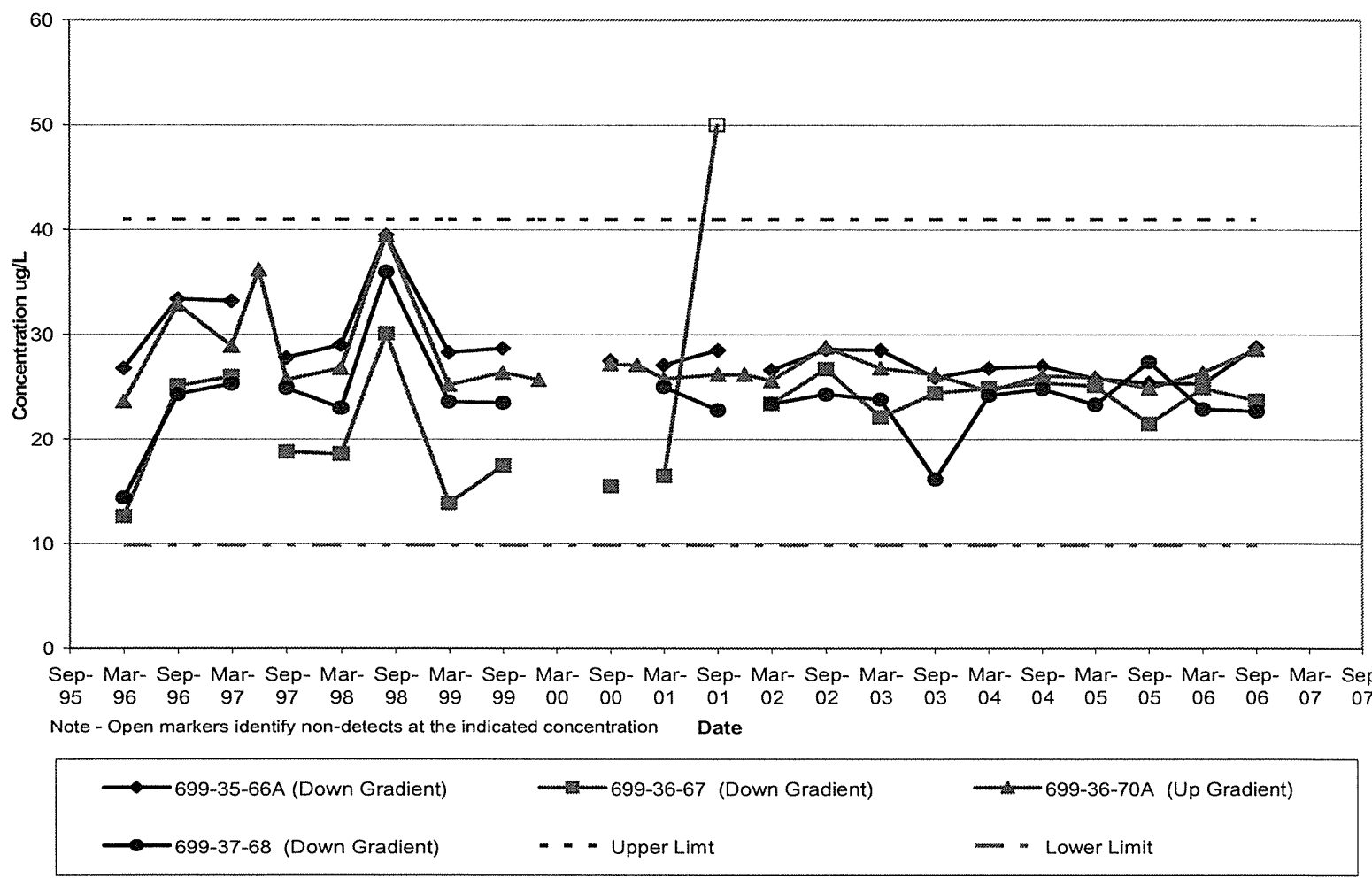


Figure B-9 Zinc (Filtered)

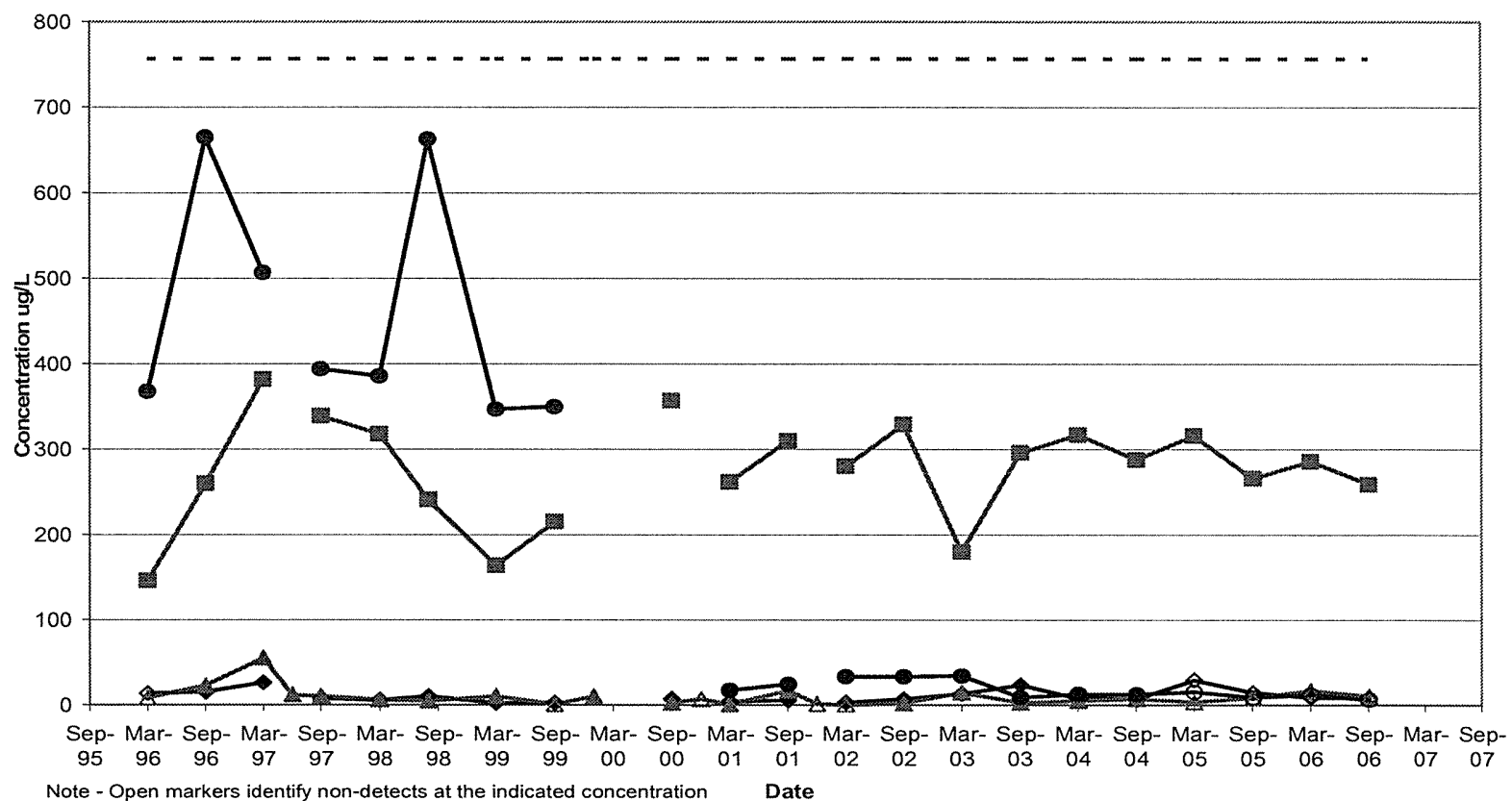

Note - Open markers identify non-detects at the indicated concentration Date

$\begin{array}{lll}\longrightarrow-699-35-66 \mathrm{~A} \text { (Down Gradient) } & -\mathrm{w}-699-36-67 \text { (Down Gradient) } & \text {-699-36-70A (Up Gradient) } \\ \longrightarrow \text { 699-37-68 (Down Gradient) } & -- \text { - Upper Limt } & \text { Lower Limit <0 - set at } 0\end{array}$


Figure B-10 Alkalinity

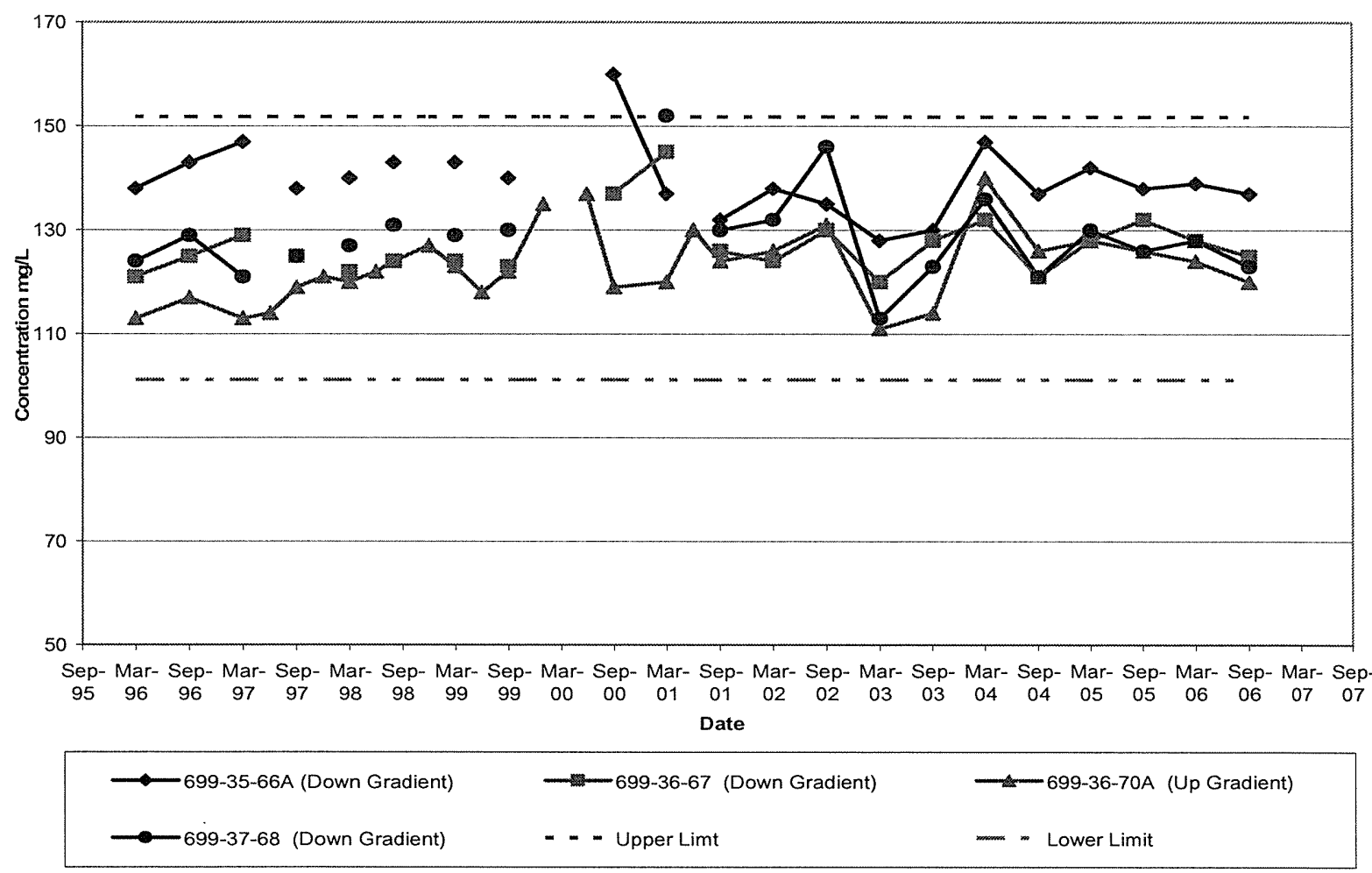


Figure B-11 Fluoride

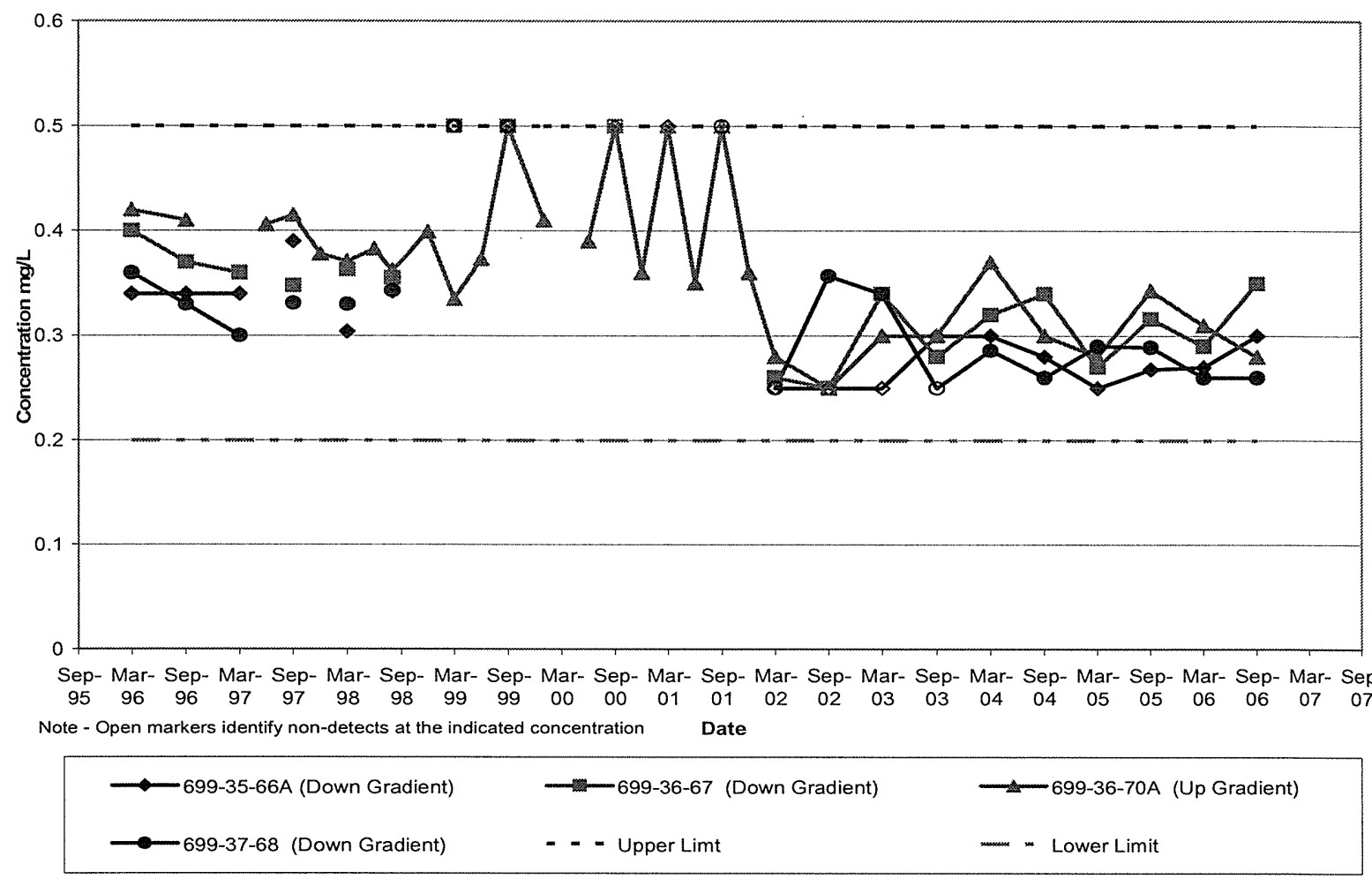


Figure B-12 Chloride

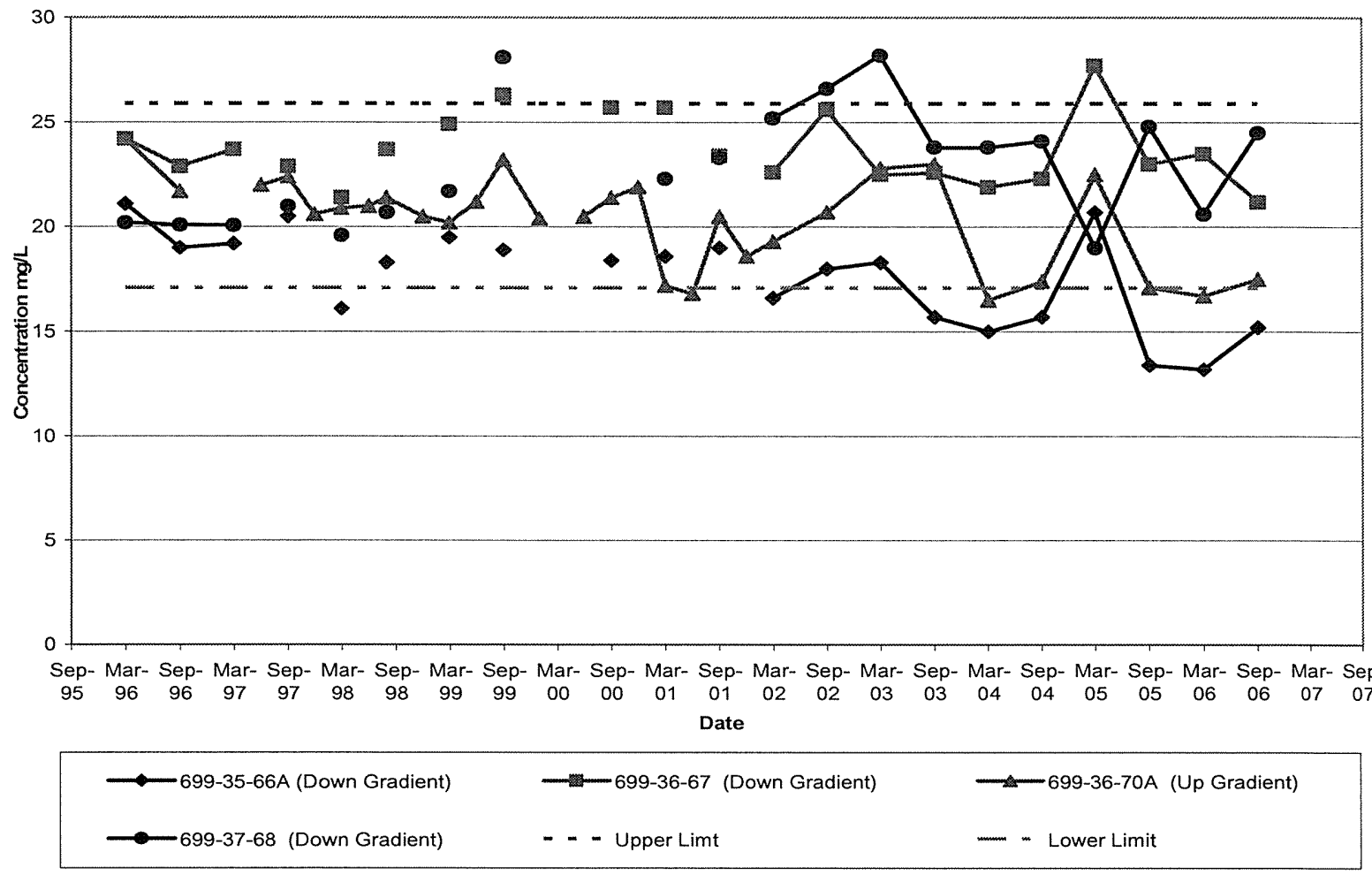


Figure B-13 Sulfate

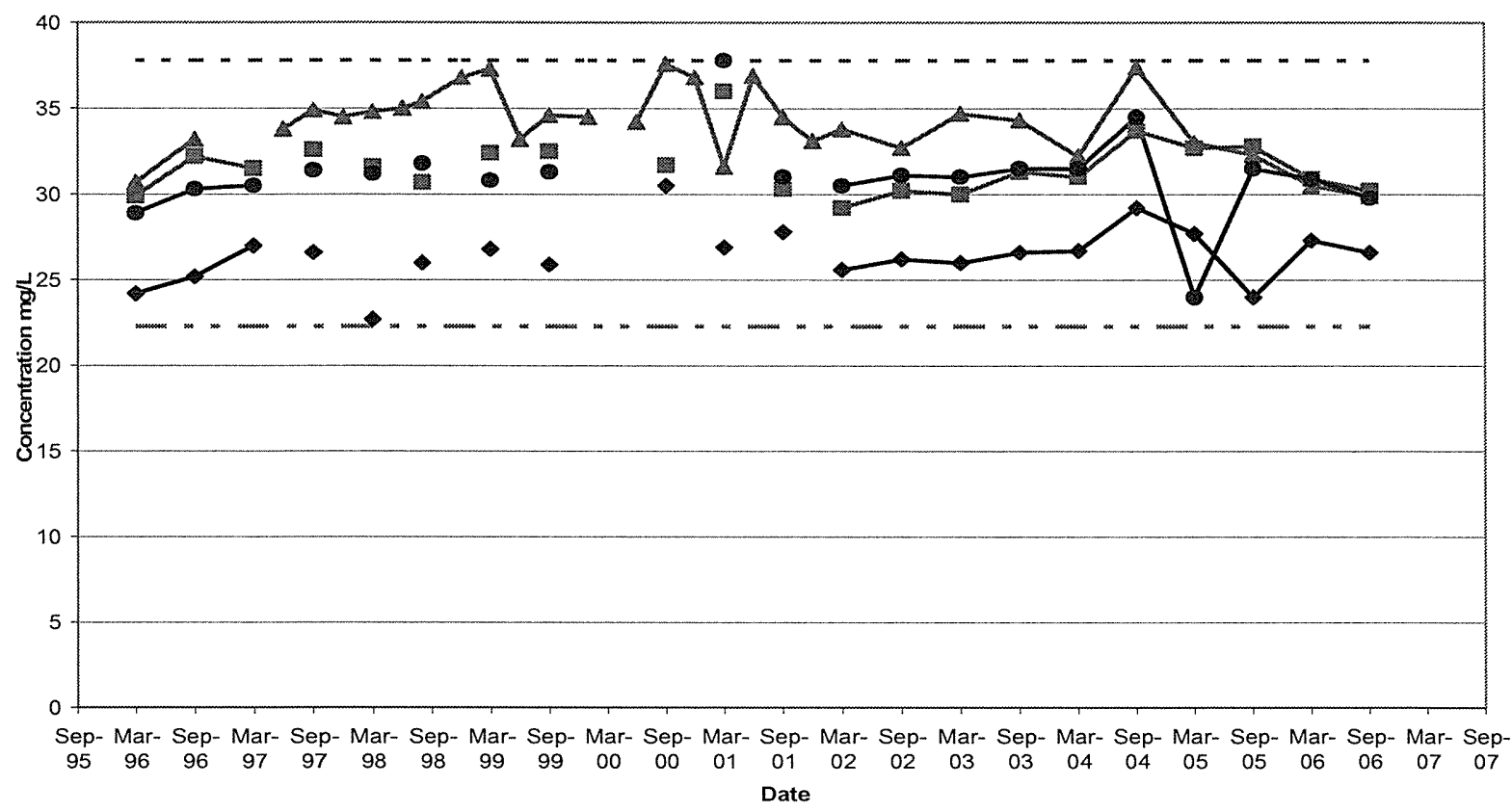

\begin{tabular}{lll}
\hline$\rightarrow 699-35-66 \mathrm{~A}$ (Down Gradient) & $-5-699-36-67$ (Down Gradient) & $-699-36-70 \mathrm{~A}$ (Up Gradient) \\
$-699-37-68$ (Down Gradient) & -- - Upper Limt & - Lower Limit \\
\hline
\end{tabular}


Figure B-14 Gross Alpha

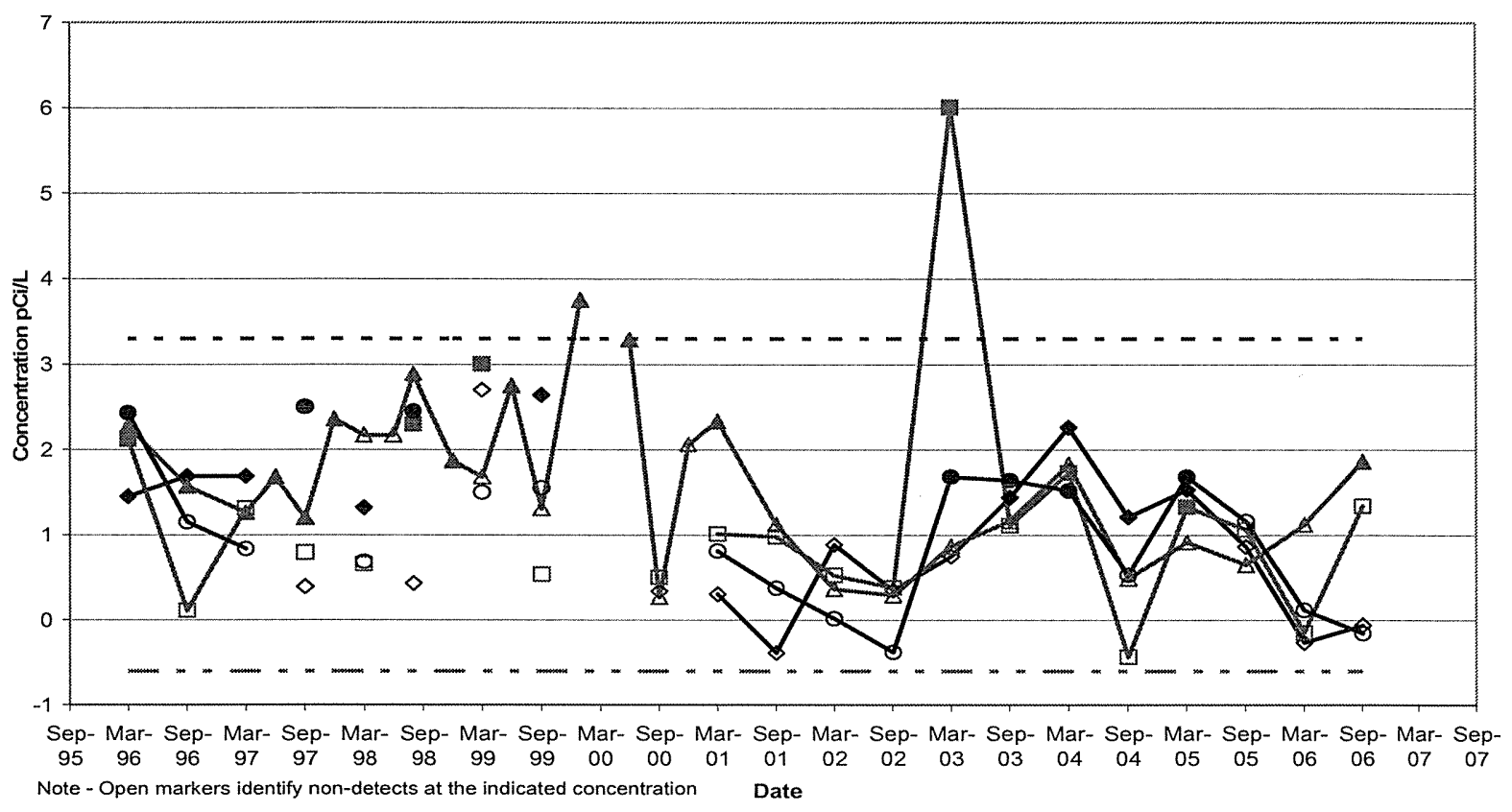

\begin{tabular}{|c|c|c|}
\hline$\longrightarrow$ 699-35-66A (Down Gradient) & $-699-36-67$ (Down Gradient) & -6 699-36-70A (Up Gradient) \\
\hline$\longrightarrow 699-37-68$ (Down Gradient) & - - - Upper Limt & - Lower Limit \\
\hline
\end{tabular}


Figure B-15 Gross Beta

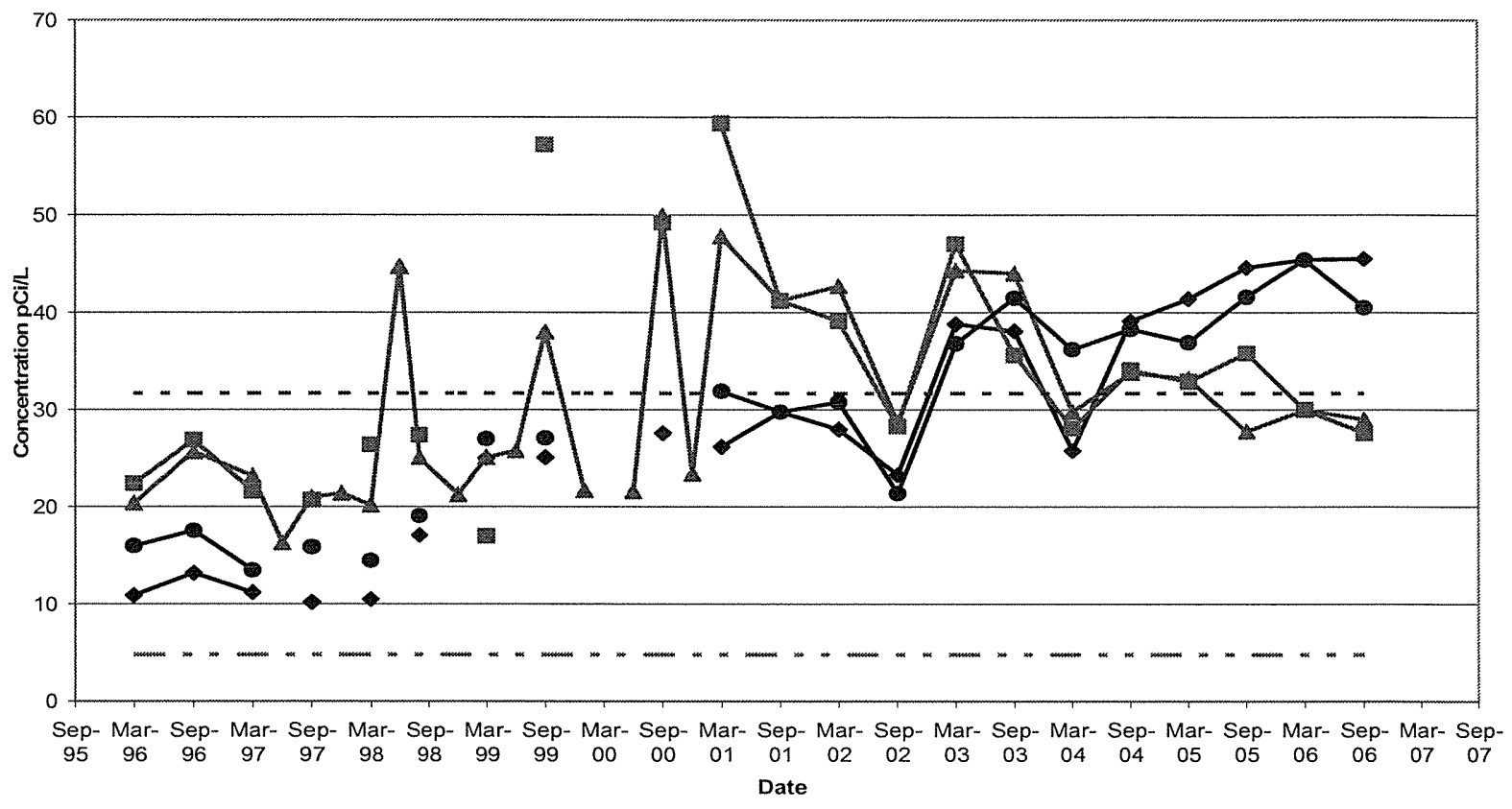

$$
\begin{array}{ll}
\longrightarrow \text { 699-35-66A (Down Gradient) } & \rightarrow \text {-699-36-67 (Down Gradient) } \\
-699-37-68 \text { (Down Gradient) } & -- \text { - Upper Limt }
\end{array}
$$


Figure B-16 Carbon-14

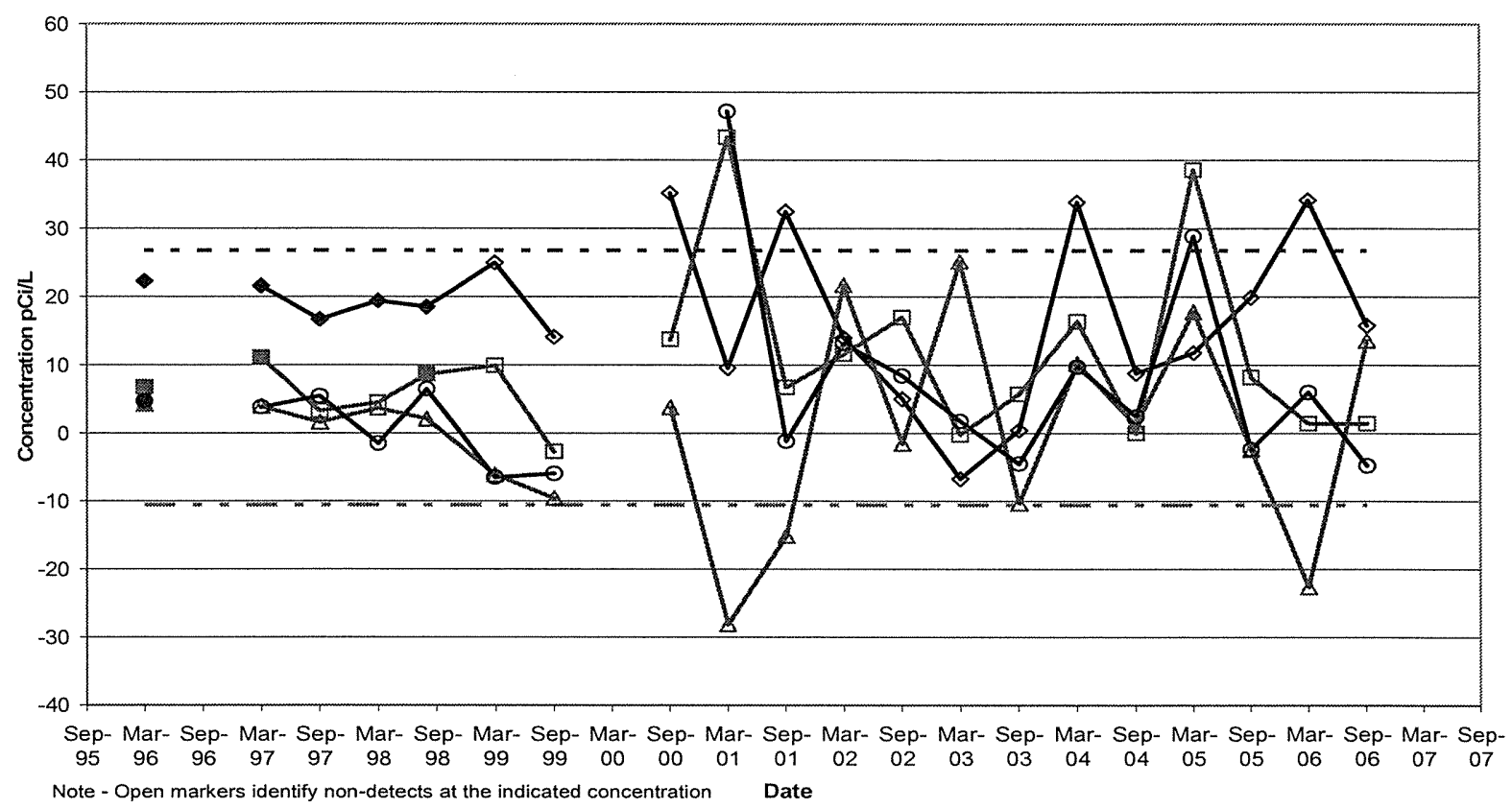

Note - Open markers identify non-detects at the indicated concentration Date

\begin{tabular}{lll}
\hline$\rightarrow 699-35-66 \mathrm{~A}$ (Down Gradient) & - 699-36-67 (Down Gradient) & 699-36-70A (Up Gradient) \\
$-699-37-68$ (Down Gradient) & -- - Upper Limt & Lower Limit \\
\hline
\end{tabular}


Figure B-17 lodine-129

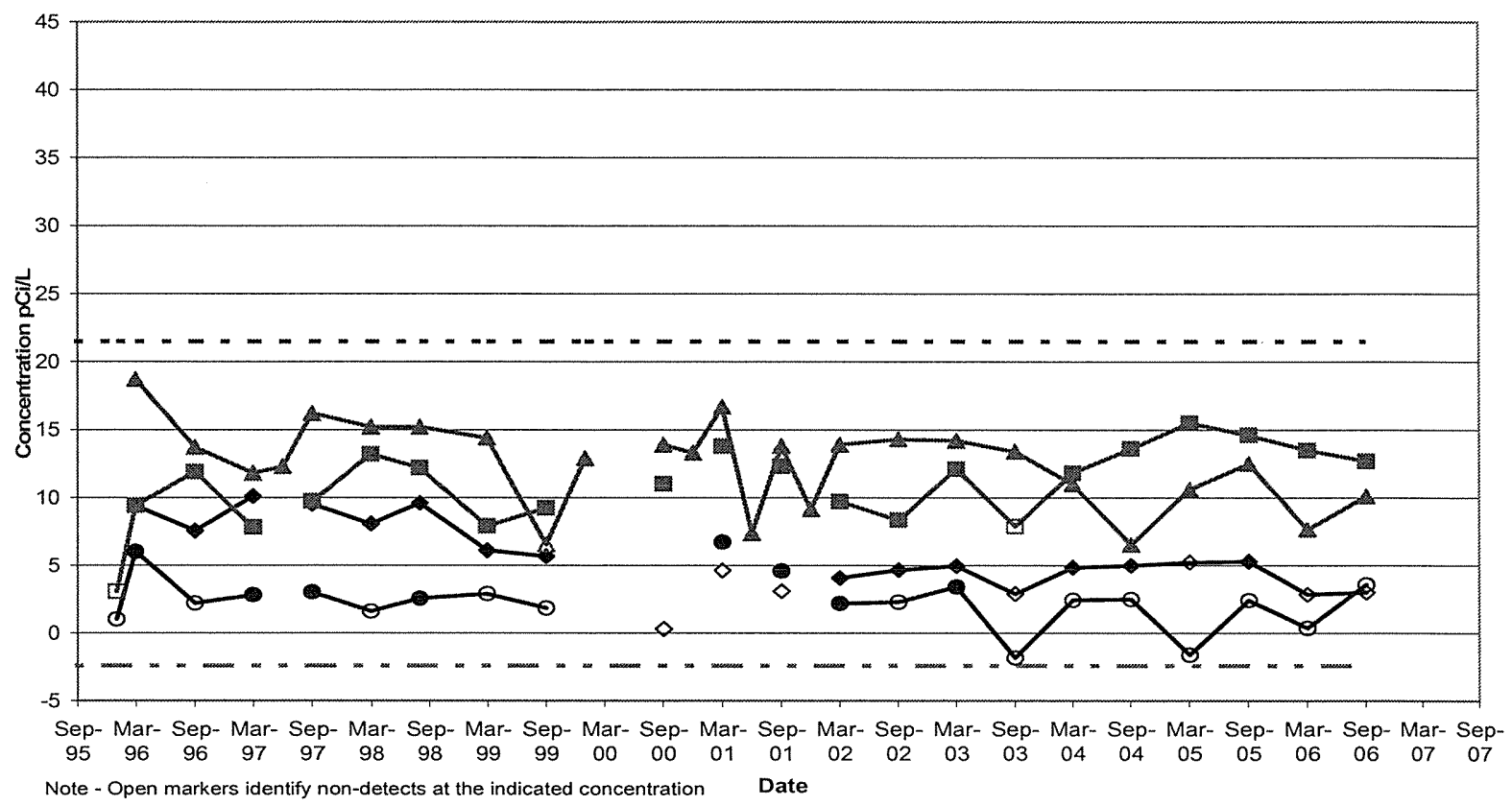

$\begin{array}{ll}\longrightarrow \text { 699-35-66A (Down Gradient) } & - \text {-699-36-67 (Down Gradient) } \\ \longrightarrow \text { 699-37-68 (Down Gradient) } & - \text { - - Upper Limt }\end{array}$


Figure B-18 Technetium-99

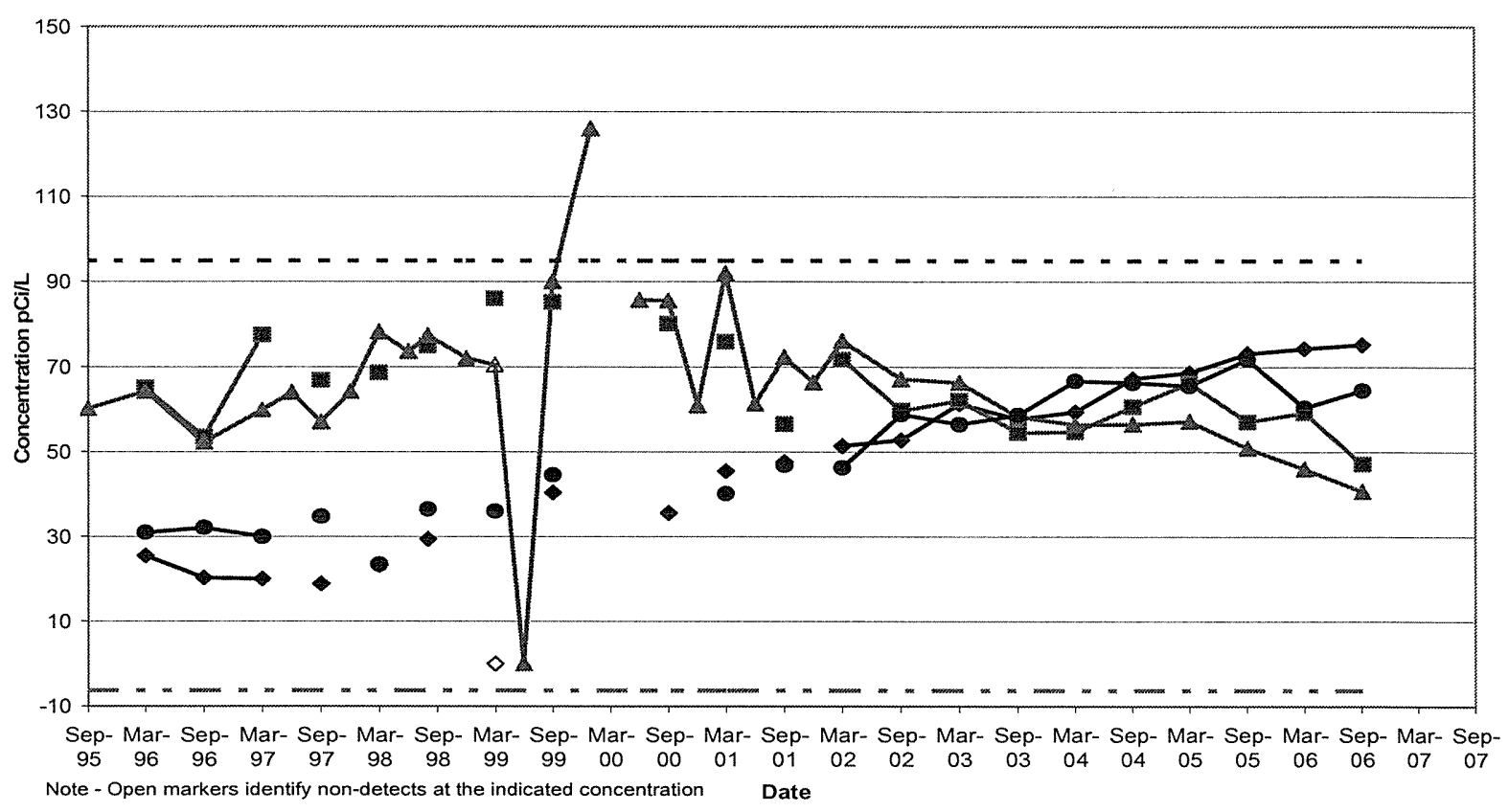

\begin{tabular}{l}
$\longrightarrow$ 699-35-66A (Down Gradient) \\
$\longrightarrow$ 699-37-68 (Down Gradient) \\
\hline- 699-36-67 (Down Gradient)
\end{tabular}


Figure B-19 Radium

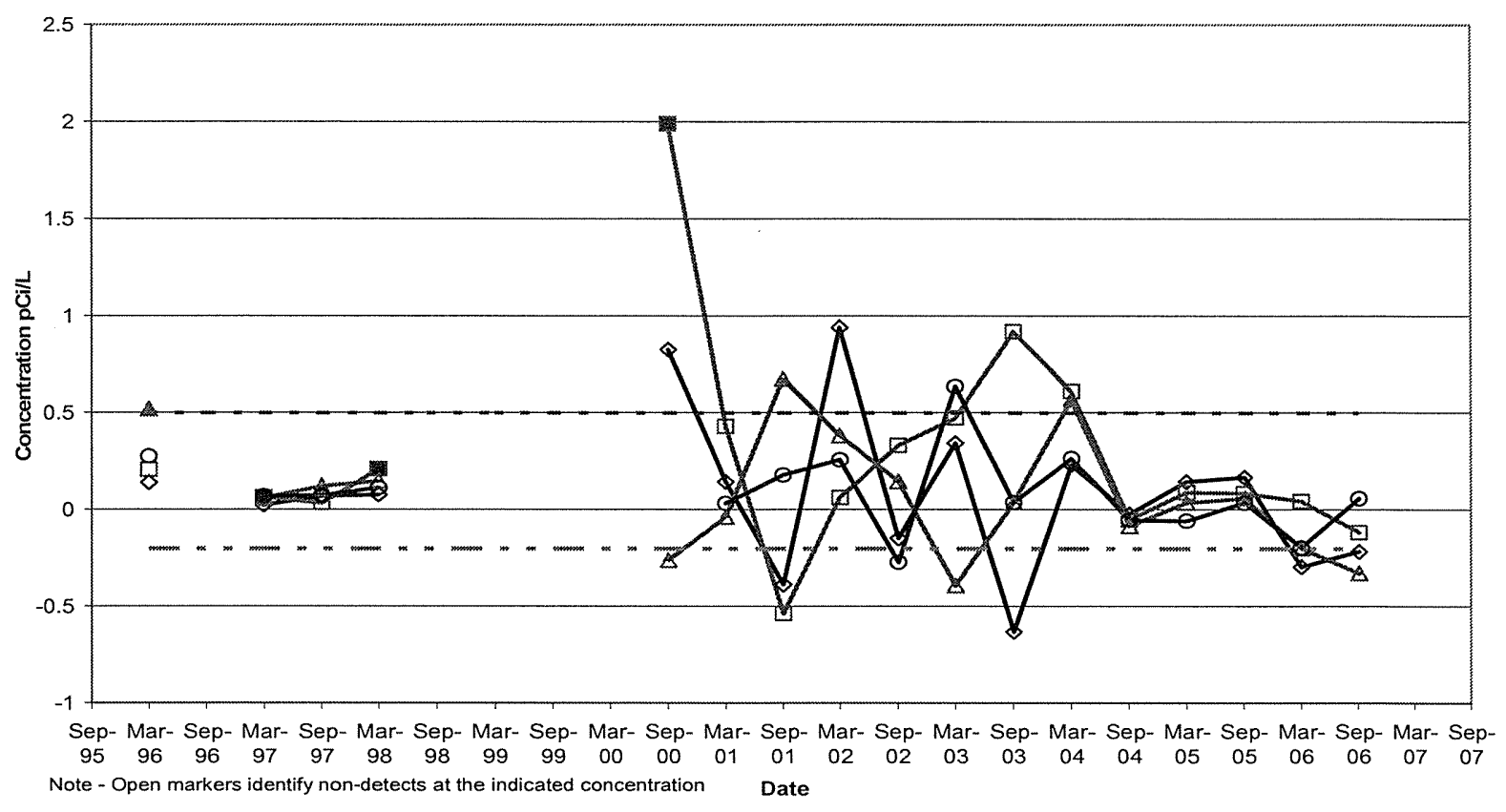
Note - Open markers identify non-detects at the indicated concentration Date

\begin{tabular}{ll}
\hline$\rightarrow$ 699-35-66A (Down Gradient) & - -699-36-67 (Down Gradient) \\
$\longrightarrow$ 699-37-68 (Down Gradient) & -- - Upper Limt
\end{tabular}


Figure B-20 Carbon Tetrachloride

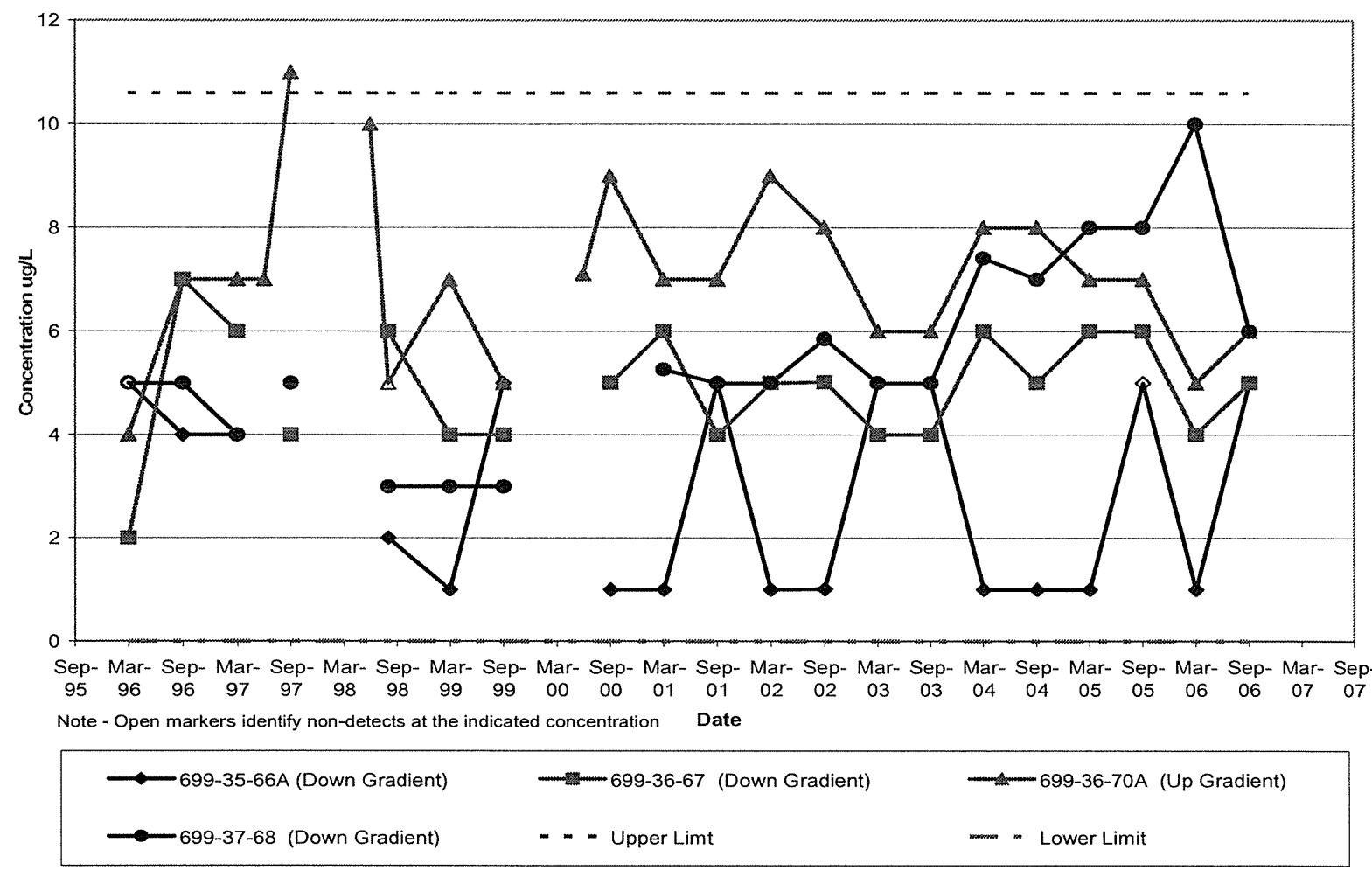


Figure B-21 Nitrogen in Nitrite and Nitrate

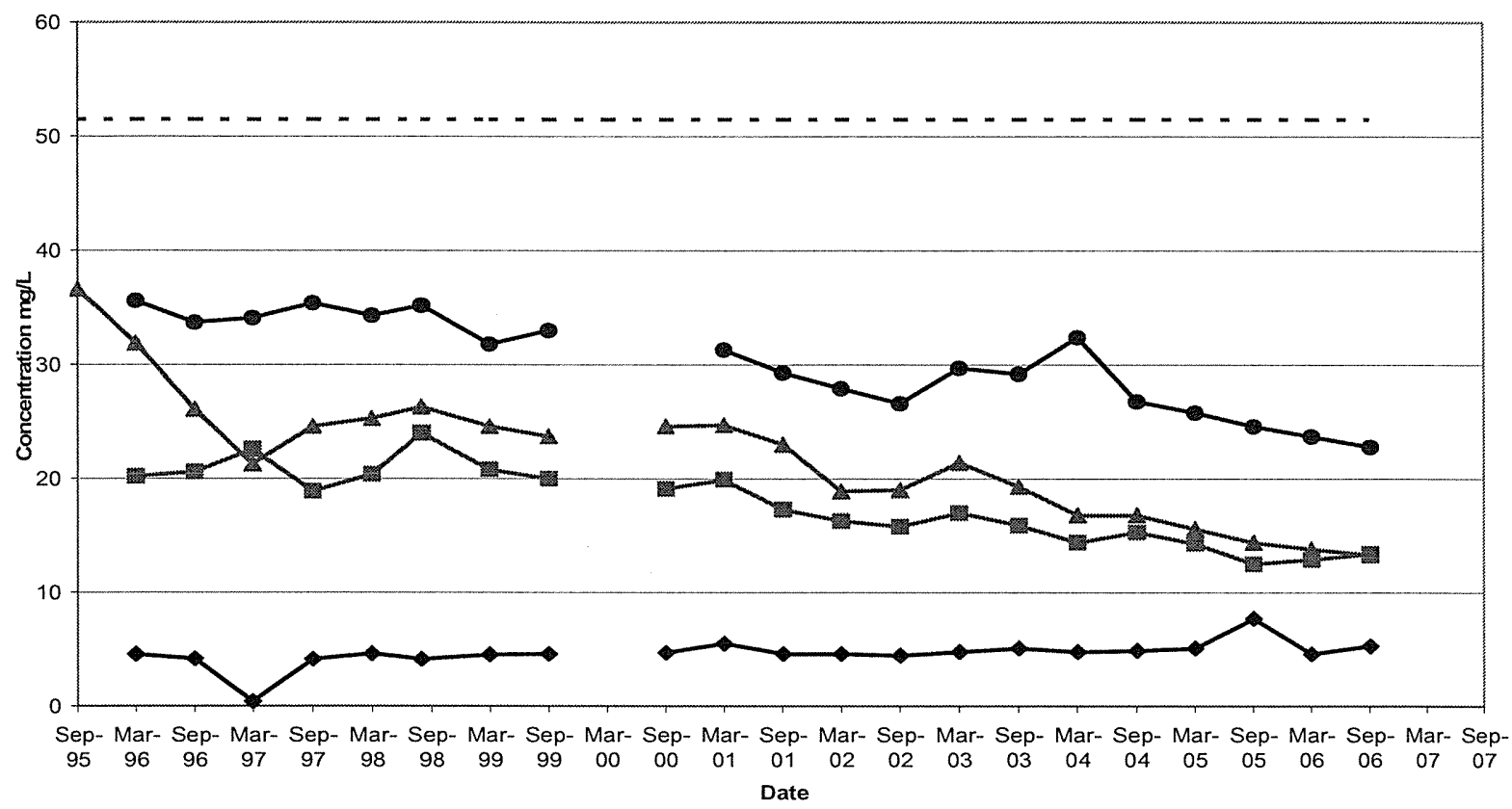

$\longrightarrow$ 699-35-66A (Down Gradient) $\quad \longrightarrow$ 699-36-67 (Down Gradient)

$\longrightarrow$ 699-37-68 (Down Gradient) - - Upper Limt

-699-36-70A (Up Gradient) Lower Limit $<0$ - set at 0 
Figure B-22 Total Organic Halides

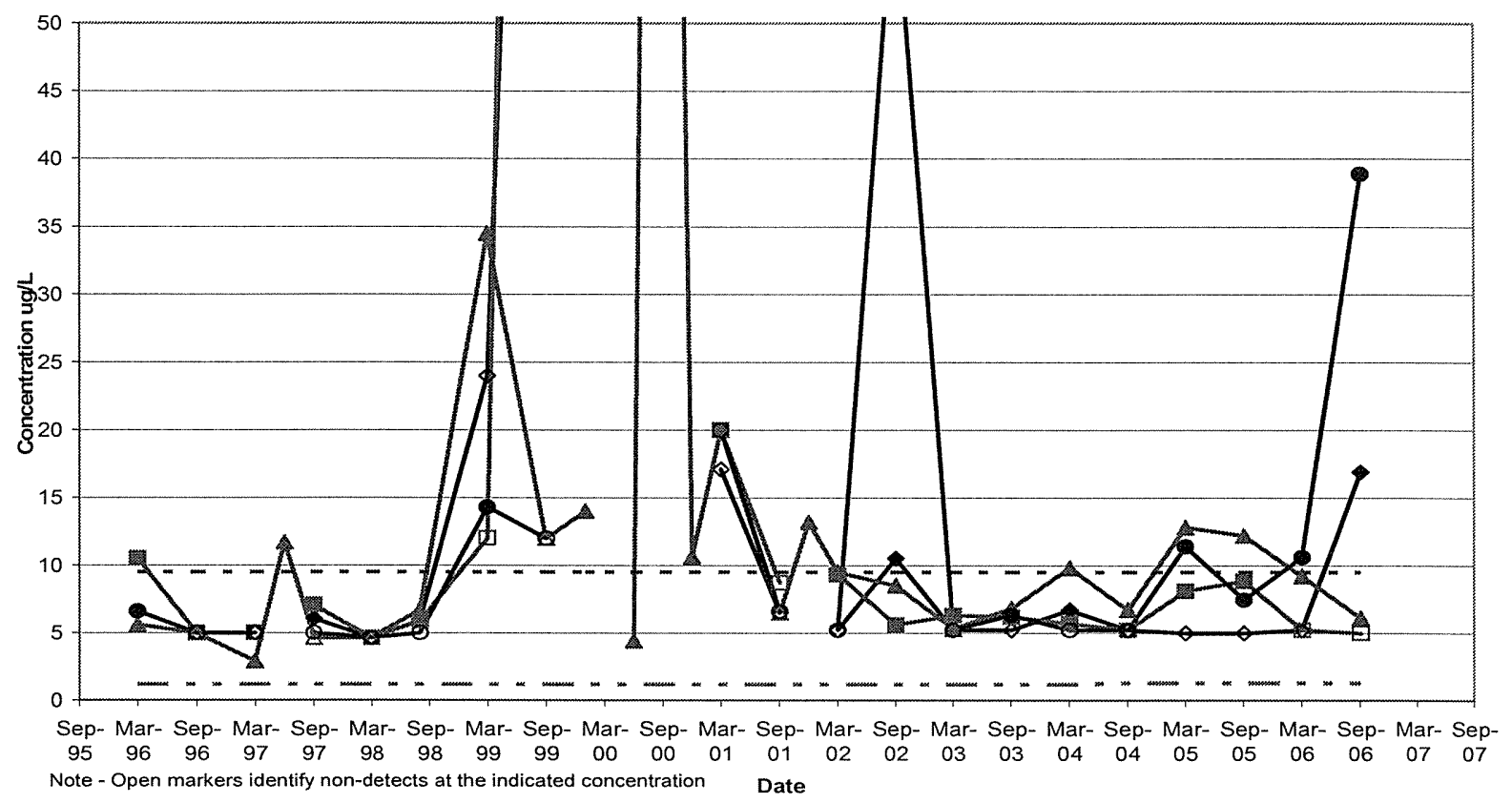

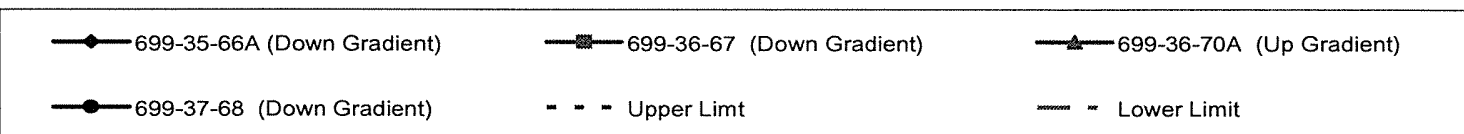


Figure B-23 Total Dissolved Solids

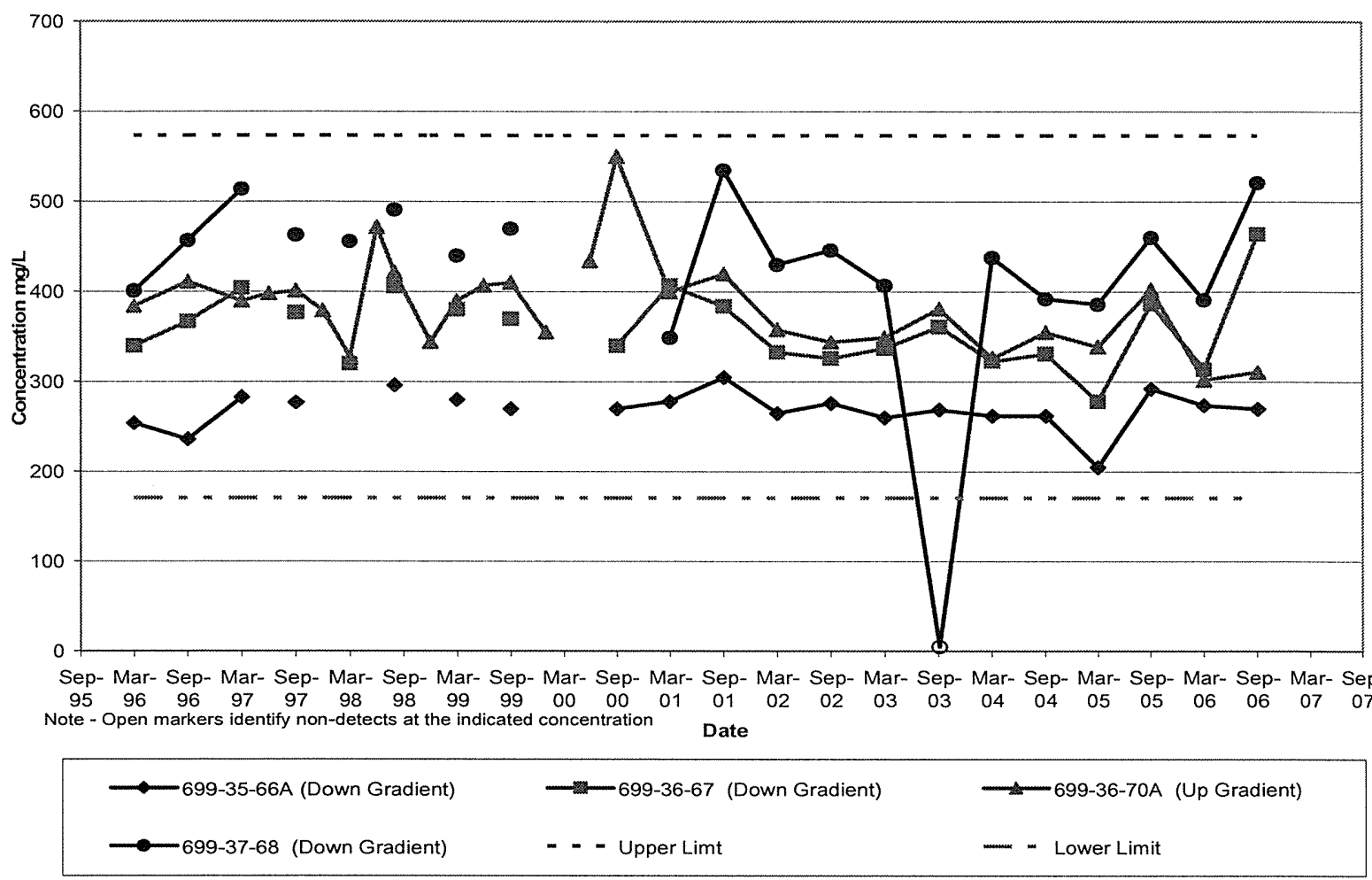


Figure B-24 Turbidity

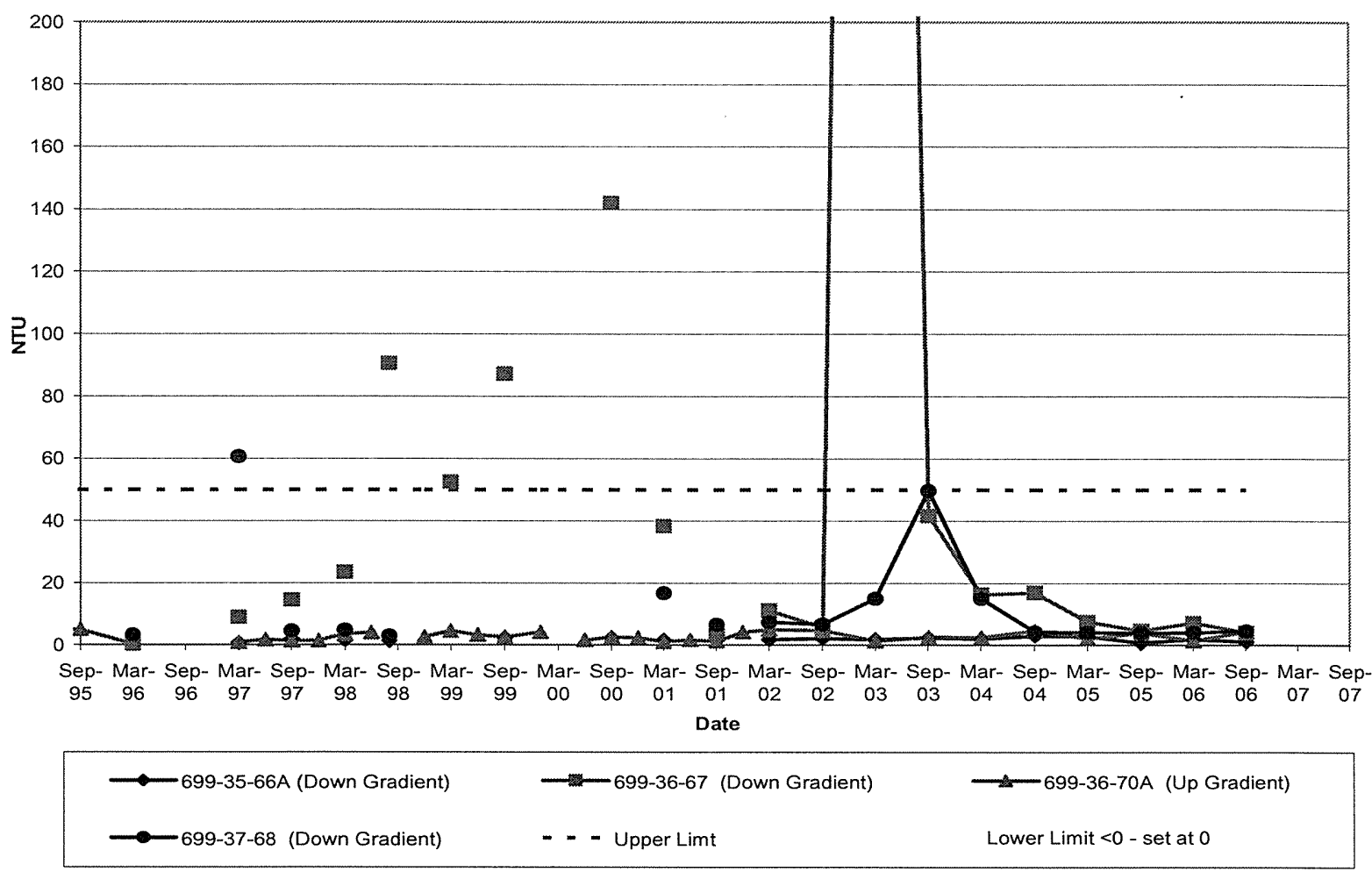


Figure B-25 pH

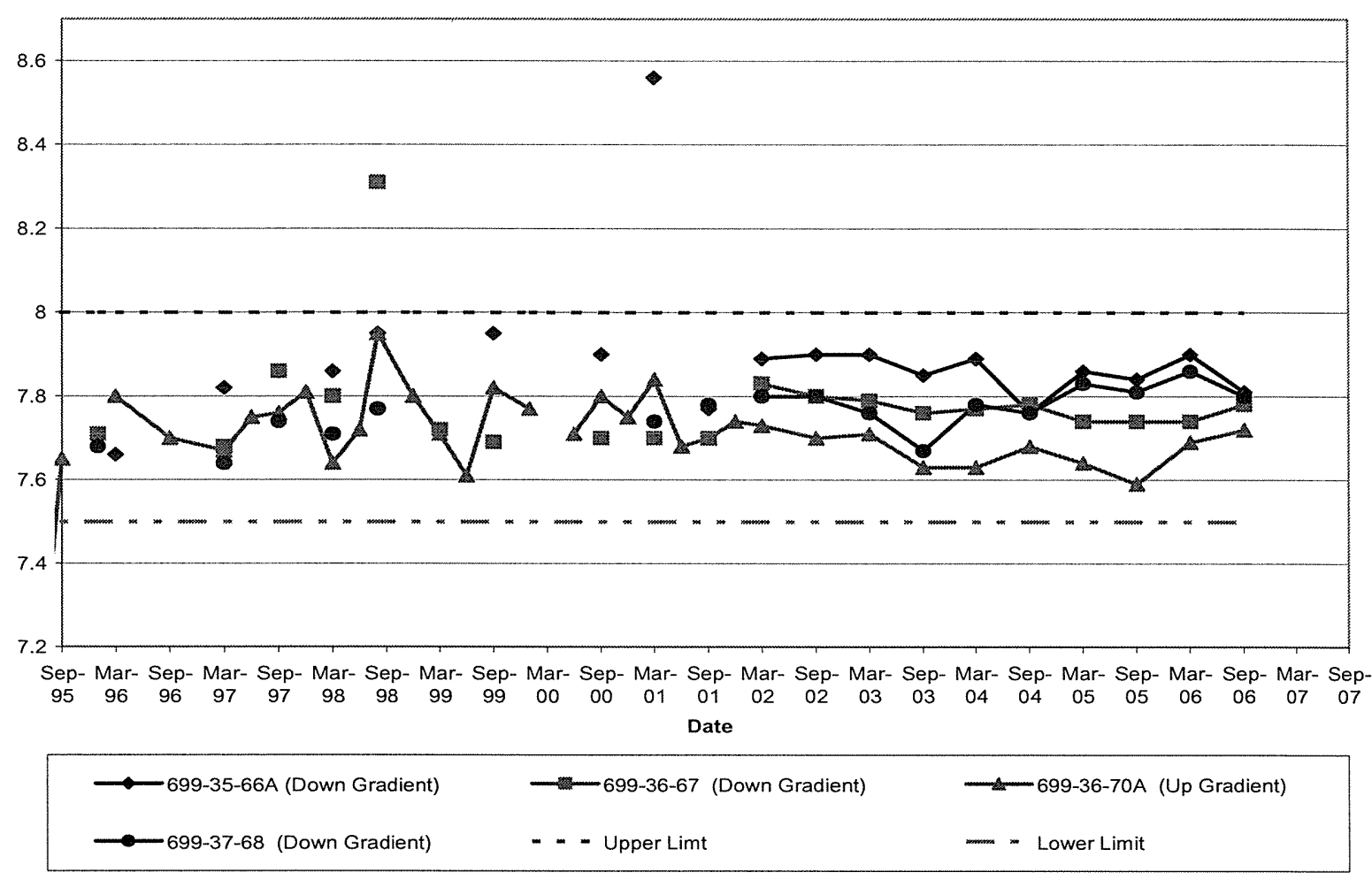


Figure B-26 Specific Conductance

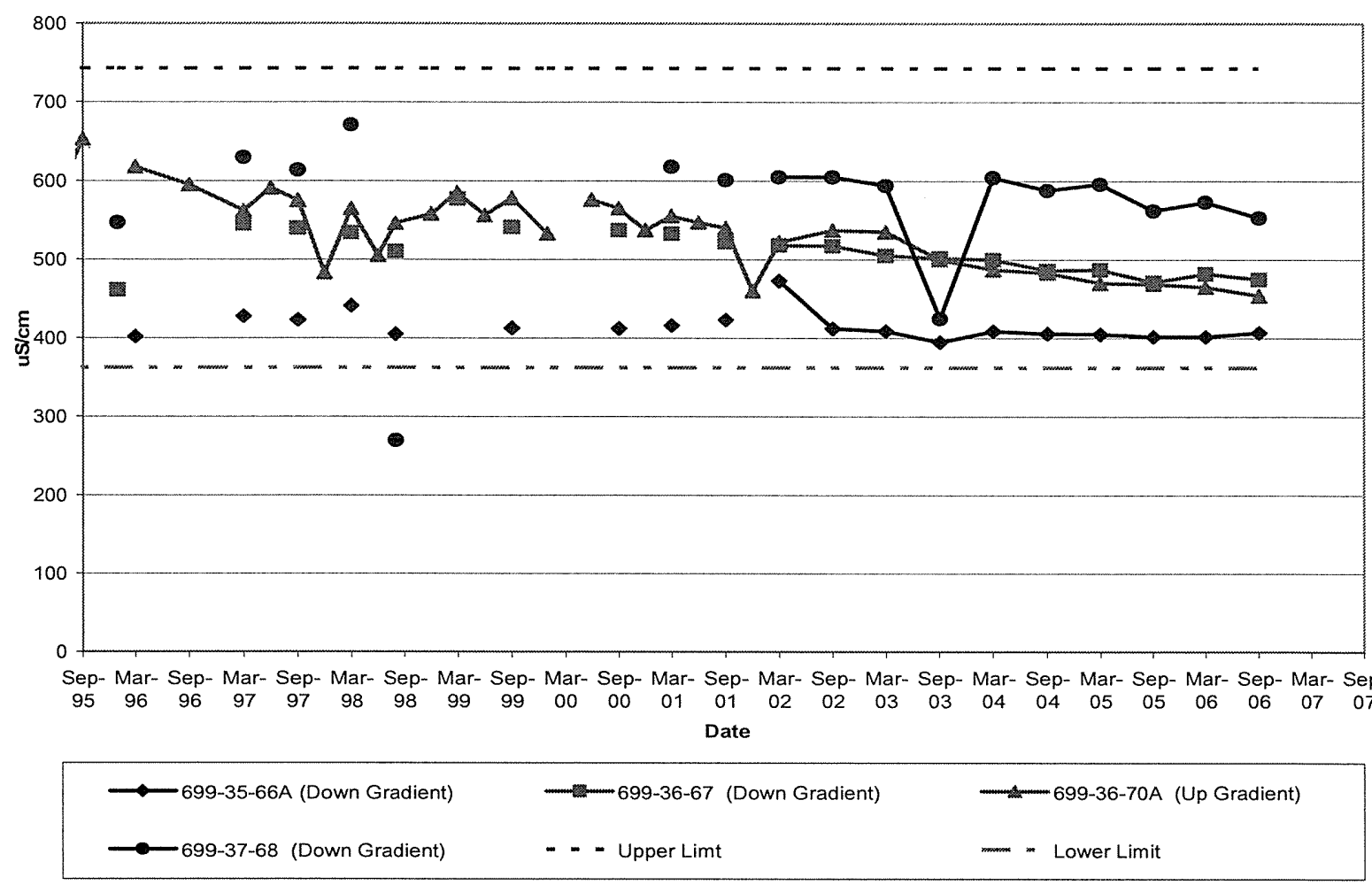




\section{APPENDIX C}

\section{LEACHATE SAMPLING SUMMARY, 2004-2006}


WCH-189

Rev. 1

GW and Leachate Monitoring and Sampling at ERDF, CY 2006 
Table C-1. Summary of Leachate Sampling Results, 2004-2006. (2 Pages)

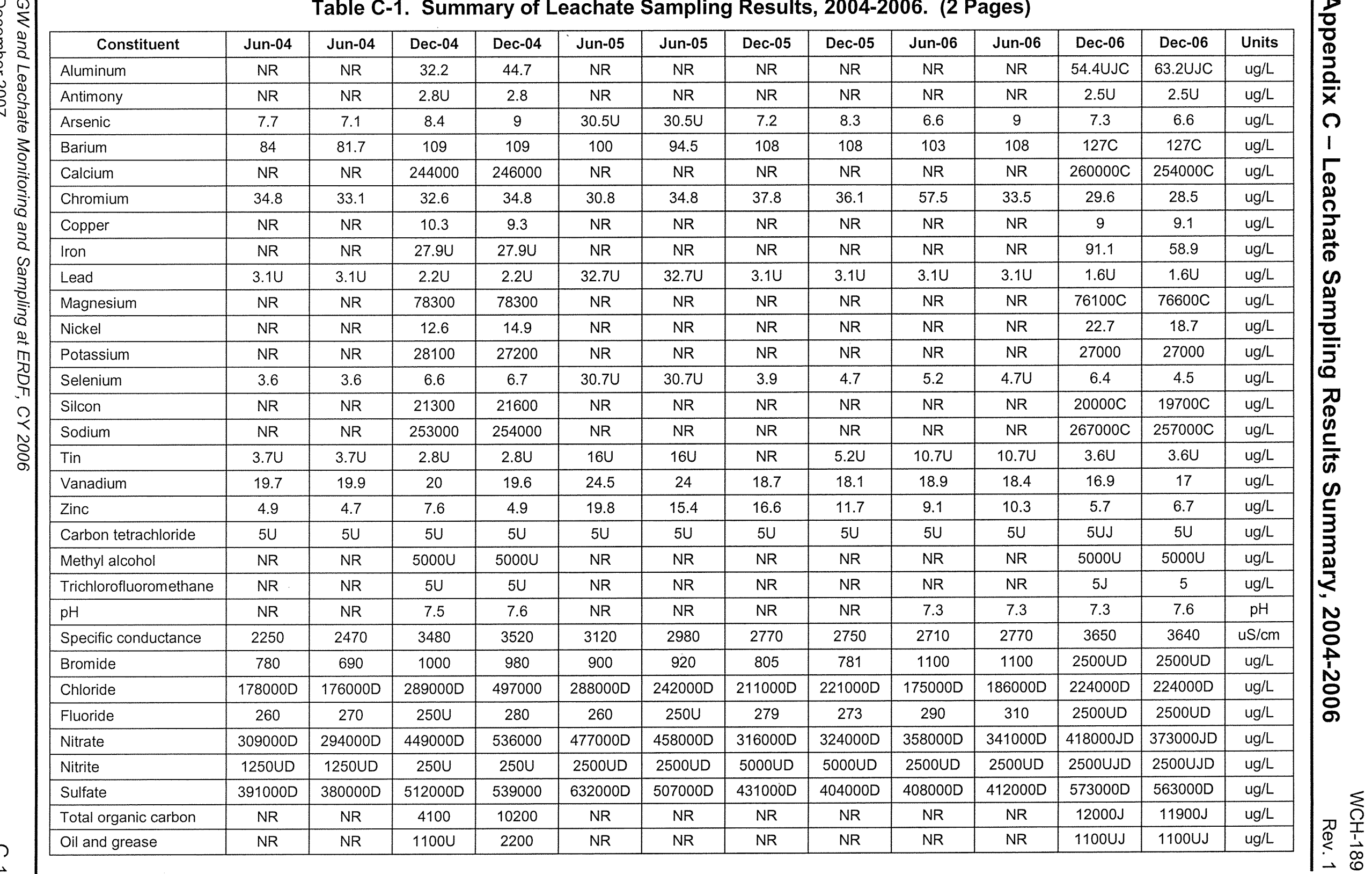


Table C-1. Summary of Leachate Sampling Results, 2004-2006. (2 Pages)

\begin{tabular}{|c|c|c|c|c|c|c|c|c|c|c|c|c|c|}
\hline Constituent & Jun-04 & Jun-04 & Dec-04 & Dec-04 & Jun-05 & Jun-05 & Dec-05 & Dec-05 & Jun-06 & Jun-06 & Dec-06 & Dec-06 & Units \\
\hline Total dissolved solids & 1820000 & 1810000 & 2490000 & 2070000 & 2200000 & 2120000 & 1920000 & 1860000 & 2040000 & 2110000 & $2280000 \mathrm{~J}$ & $2360000 \mathrm{~J}$ & $\mathrm{ug} / \mathrm{L}$ \\
\hline Total suspended solids & & & $5000 U$ & $5000 \mathrm{U}$ & NR & NR & NR & NR & NR & NR & $5000 \mathrm{UJ}$ & $5000 \mathrm{UJ}$ & $\mathrm{ug} / \mathrm{L}$ \\
\hline Gross alpha & 526 & 422 & 232 & 277 & 414 & 445 & 444 & 340 & 652 & 578 & 1310 & 1090 & $\mathrm{pCi} / \mathrm{L}$ \\
\hline Gross beta & 515 & 514 & 520 & 533 & 736 & 704 & 530 & 471 & 633 & 613 & 764 & 1100 & $\mathrm{pCi} / \mathrm{L}$ \\
\hline Carbon-14 & $27.2 U$ & $29.2 U$ & 104 & $57.7 \mathrm{U}$ & $75.8 U$ & $67.7 \mathrm{U}$ & $12.8 \mathrm{U}$ & $25.3 \mathrm{U}$ & $33.4 \mathrm{U}$ & $46.8 U$ & $118 U$ & $20.1 U$ & $\mathrm{pCi} / \mathrm{L}$ \\
\hline Technetium-99 & 717 & 628 & 805 & 858 & 808 & 814 & 631 & 612 & 738 & 55.4 & 738 & 817 & $\mathrm{pCi} / \mathrm{L}$ \\
\hline Uranium (Total) & 756 & 751 & 953 & 933 & 1090 & 1030 & 941 & 754 & 930 & 932 & 1730 & 1740 & $\mathrm{ug} / \mathrm{L}$ \\
\hline lodine-129 & $-1.1 U$ & $-0.524 U$ & $0.288 U$ & $0.792 \mathrm{U}$ & $-0.366 \mathrm{U}$ & $0.41 \mathrm{U}$ & $0.951 \mathrm{U}$ & $0.844 \mathrm{U}$ & $-1.2 U$ & $-2.61 U$ & $-0.375 \mathrm{U}$ & $-0.481 U$ & $\mathrm{pCi} / \mathrm{L}$ \\
\hline $\begin{array}{l}\text { Total radium alpha } \\
\text { emissions }\end{array}$ & $-0.246 \mathrm{U}$ & $-0.067 \mathrm{U}$ & $0.193 \mathrm{U}$ & $-0.044 U$ & $0.054 \mathrm{U}$ & $0.06 \mathrm{U}$ & $-0.02 U$ & $0.135 \mathrm{U}$ & $-0.168 U$ & $0.022 \mathrm{U}$ & $-0.316 \mathrm{U}$ & $-0.046 \mathrm{U}$ & $\mathrm{pCi} / \mathrm{L}$ \\
\hline
\end{tabular}

$U=$ Result is nondetected.

$D=$ Result reported from secondary dilution.

C = Analyte detected in associated laboratory batch blank

$=$ Value is an estimate.

$N R=$ Not requested for this analysis round 
Table C-2. Leachate Long List Analytes. (2 Pages)

\begin{tabular}{|c|c|c|c|}
\hline Constituent & Constituent & Constituent & Constituent \\
\hline Aluminum & 1,2-cis-Dichloroethene & 2,4,6-Trichlorophenol & Nitrobenzene \\
\hline Antimony & 1,2-Dichloroethane & 2,4-Dichlorophenol & N-Nitroso-di-n-propylamine \\
\hline Arsenic & 1,2-Dichloropropane & 2,4-Dimethylphenol & N-Nitrosodiphenylamine \\
\hline Barium & 1,2-trans-Dichloroethene & 2,4-Dinitrophenol & N-Nitrosomorpholine \\
\hline Beryllium & 1,3-Butadiene & 2,5-Diamintoluene & $\mathrm{N}-\mathrm{Nitroso}-\mathrm{N}, \mathrm{N}$-dimethylamine \\
\hline Cadmium & cis-1,3-Dichloropropene & 2-Chloronaphthalene & $\begin{array}{l}\text { O,O,O-Triethyl } \\
\text { phosphorothioate }\end{array}$ \\
\hline Calcium & trans-1,3-Dichloropropene & 2-Chlorophenol & Pentachlorophenol \\
\hline Chromium & 1,4-Dioxane & $\begin{array}{l}\text { 2-Cyclohexyl-4,6- } \\
\text { dinitrophenol }\end{array}$ & Phenol \\
\hline Cobalt & 1-Chloroethene (Vinyl Chloride) & 2-Naphthylamine & p-Phenylenediamine \\
\hline Copper & (1-Methylethyl)benzene & 4-Bromophenylphenyl ether & Pyrene \\
\hline Lead & 2-Butanone (MEK) & 4-Chloro-3-methylphenol & Pyridine \\
\hline Magnesium & 2-Butenaldehyde (Crotonaldehyde) & 4-Nitrophenol & Tetrahydrofuran \\
\hline Manganese & 2-Chloroethyl vinyl ether & $\begin{array}{l}7,12- \\
\text { Dimethylbenz[a]anthracene }\end{array}$ & Formaldehyde \\
\hline Nickel & $\begin{array}{l}\text { 2-Methyl-2-propenenitrile } \\
\text { (Methacrylonitrile) }\end{array}$ & Acenaphthene & Bendiocarb \\
\hline Potassium & $\begin{array}{l}\text { 2-Methylpropyl alcohol (Isobutyl } \\
\text { alcohol) }\end{array}$ & Acetophenone & Cyanide \\
\hline Selenium & 2-Propanone (Acetone) & alpha-Naphthylamine & Sulfide \\
\hline Silcon & 2-Propen-1-ol (Allyl alcohol) & Aniline & $\mathrm{pH}$ \\
\hline Silver & 3-Chloropropene (Allyl chloride) & Anthracene & Specific Conductance \\
\hline Sodium & 4-Methyl-2-pentanone (MIBK) & Benzo(a)anthracene & Bromide \\
\hline Thallium & $\begin{array}{l}\text { Acetic acid ethyl ester (Ethyl } \\
\text { acetate) }\end{array}$ & Benzo(a)pyrene & Chloride \\
\hline Tin & $\begin{array}{l}\text { Acetic acid vinyl ester (Vinyl } \\
\text { acetate) }\end{array}$ & Benzo(b)fluoranthene & Fluoride \\
\hline Vanadium & Acetonitrile & Benzo(k)fluoranthene & Nitrate \\
\hline Zinc & Acrolein & Benzyl alcohol & Nitrite \\
\hline Mercury & Acrylonitrile & Bis(2-Chloroethoxy)methane & Phosphate \\
\hline 4,4-DDD & Benzene & Bis(2-chloroethyl) ether & Sulfate \\
\hline 4,4-DDE & Bromodichloromethane & Bis(2-Chloroisopropyl) ether & Ammonia \\
\hline 4,4-DDT & Bromomethane & Bis(2-ethylhexyl) phthalate & Total Organic Carbon \\
\hline Aldrin & Carbon disulfide & Butylbenzylphthalate & Oil \& Grease \\
\hline alpha-BHC & Carbon tetrachloride & Chrysene & Total Dissolved Solids \\
\hline beta-BHC & Chlorobenzene & o-Cresol & Total Suspended Solids \\
\hline Dieldrin & Chloroethane & m-Cresol & Gross alpha \\
\hline Endrin & Chloroform & $\mathrm{p}$-Cresol & Gross beta \\
\hline Gamma-BHC (lindane) & Chloromethane & Dibenz[a,h]anthracene & Carbon-14 \\
\hline Heptachlor & Dibromochloromethane & 1,2-Dichlorobenzene & Technetium-99 \\
\hline Heptachlor Epoxide & Dichlorodifluoromethane & 1,3-Dichlorobenzene & Uranium (Total) \\
\hline
\end{tabular}


Table C-2. Leachate Long List Analytes. (2 Pages)

\begin{tabular}{|c|c|c|c|}
\hline Constituent & Constituent & Constituent & Constituent \\
\hline Toxaphene & $\begin{array}{l}\text { Dichloromethane (Methylene } \\
\text { Chloride) }\end{array}$ & 1,4-Dichlorobenzene & Potassium-40 \\
\hline PCB-1016 & Dichloroproponol & Diethyl phthalate & Cobalt-60 \\
\hline PCB-1221 & Ethyl benzene & Dimethyl phthalate & Cesium-137 \\
\hline PCB-1232 & Ethyl ether & Di-n-butylphthalate & Europium-152 \\
\hline PCB-1242 & Ethylene dibromide & 1,3-Dinitrobenzene & Europium-154 \\
\hline PCB-1248 & Methyl alcohol & 1,4-Dinitrobenzene & Europium-155 \\
\hline PCB-1254 & n-Butyl alcohol & Di-n-octylphthalate & Radium-226 \\
\hline PCB-1260 & Styrene & Ethyl methanesulfonate & Radium-228 \\
\hline $2,4-D$ & Toluene & Fluoranthene & Thorium-228 \\
\hline 1,1,1-Trichloroethane & Tribromomethane (Bromoform) & Fluorene & Thorium-232 \\
\hline $\begin{array}{l}1,1,2,2- \\
\text { Tetrachloroethane }\end{array}$ & Trichlorofluoromethane & Hexachlorobutadiene & Uranium-235 \\
\hline $\begin{array}{l}1,1,2,2- \\
\text { Tetrachloroethene }\end{array}$ & Trichloromethanetiol & Hexachloroethane & Uranium-238 \\
\hline 1,1,2-Trichloroethane & Xylene & Hexachlorophene & Americium-241 \\
\hline 1,1,2-Trichloroethylene & 1,2,4-Trichlorobenzene & Indeno(1,2,3-cd)pyrene & lodine-129 \\
\hline 1,1-Dichloroethane & 1,2-Diphenylhydrazine & Isophorone & Total radium alpha emissions \\
\hline 1,1-Dichloroethene & 1-Acetyl-2-thiourea & N,N-Diphenylamine & \\
\hline $\begin{array}{l}1,2,2- \\
\text { Trichlorotrifluoroethane }\end{array}$ & 2,4,5-Trichlorophenol & Naphthalene & \\
\hline
\end{tabular}




\section{DISTRIBUTION}

Washington Closure Hanford

M A. Casbon T2-03

K. A. Hadley T2-04

W. E. Remson T2-03

$\begin{array}{ll}\text { J. E. Rugg T2-04 } & \text { Th }\end{array}$

Document Control H4-11

DOE-RL Public Reading Room H2-53

Hanford Technical Library $\quad$ P8-55 
WCH-189

Rev. 1

GW and Leachate Monitoring and Sampling at ERDF, CY 2006

December 2007

Distr-2 